\title{
RESUMOS DE DISSERTAÇÕES DE MESTRADO E TESES DE DOUTORADO APRESENTADAS NA FACULDADE DE MEDICINA DE RIBEIRÃO PRETO DA UNIVERSIDADE DE SÃO PAULO DE JULHO A SETEMBRO DE 2008
}

\author{
BIOLOGIA CELULAR E MOLECULAR
}

\section{INFECÇÃO EXPERIMENTAL DE CAMUNDONGOS BALB/C NEONATOS INOCULADOS PELA VIA SUBCUTÂNEA COM VÍRUS OROPOUCHE}

\section{Rodrigo Ivo Marques dos Santos}

Orientador: Prof. Dr. Eurico Arruda Neto

Tese de Doutorado apresentada em 11/08/2008

O vírus Oropouche, da família Bunyaviridae, gênero OrthoBunyavirus, sorogrupo Simbu, é um importante agente causador de arbovirose febril no Brasil. É estimado que 500.000 casos de febre do Oropouche tenham acontecido no Brasil nos últimos 30 anos, com casos registrados também no Panamá, Peru, Suriname e Trinidad. Aquecimento global e redistribuição de vetores e reservatórios podem aumentar o risco da disseminação de vírus Oropouche para outras áreas da América do Sul. Nós desenvolvemos um modelo experimental de infecção por vírus Oropouche em camundongos $\mathrm{BALB} / \mathrm{c}$ neonatos por meio de inoculação subcutânea. A grande maioria dos animais infectados desenvolveram doença no quinto dia pós-infecção, caracterizada principalmente por letargia e paralisia, progredindo para óbito em 10 dias. Replicação viral foi documentada no cére- bro por hibridação in situ e titulação de vírus viáveis. Histopathologia revelou achados leves no cérebro e medula espinhal, com reação glial e ativação de astrócitos progredindo da medula para o cérebro. Hiperplasia esplênica, células gigantes no fígado e meningite leve foram também encontradas, sem detecção de vírus viável no fígado e no baço. ORO causou apoptose de grande número de células, principalmente neurônios, mas também de astrócitos. A inoculação de vírus diretamente no nervo ciático causou paralisia grave e morte, enquanto em animais inoculados no ciático seguido de amputação do nervo não desenvolveram doença.

ORO causa doença em camundongos BALB/c lactentes por inoculação subcutânea, com grave envolvimento do SNC, achados histopatológicos leves, virtual ausência de inflamação. ORO causou marcada apoptose, principalmente de neurônios. Esse estudo não apenas contribui para entender a biologia de ORO, mas também pode ser importante para testar novas intervenções antivirais para este importante vírus.

\section{ESTUDO FENOTÍPICO E MOLECULAR DA RESISTÊNCIA AOS $\beta$-LACTÂMICOS E GLICOPEPTÍDEOS EM LINHAGENS DE ESTAFILOCOCOS}

\section{Izabel Cristina Vanzato Palazzo}

Orientadora: Profa. Dra. Ana Lúcia da Costa Darini

Tese de Doutorado apresentada em 12/09/2008

Este estudo propôs um método simples, denominado disco-difusão quantitativo (DD quantitativo), para determinação de concentração inibitória mínima (CIM) para oxacilina em linhagens de estafilococos. Também, foram analisados o operon mec de sete linhagens de estafilococos (3 Staphylococcus aureus e 4 estafilococos coagulase-negativos-ECN) que apresentaram fenótipo e genótipo dis- crepantes quanto à resistência à oxacilina. Devido à importância de outras espécies de estafilococos no contexto da resistência a antimicrobianos, foram estudadas seis linhagens de S. hominis subsp. novobiosepticus (SHN) que foram causa de sepse em pacientes hospitalizados. Para a determinação da CIM pelo DD quantitativo, foram utilizados discos impregnados com várias concentrações do antibiótico. Os tamanhos dos halos de inibição do crescimento bacteriano ao redor de cada disco foram medidos e a CIM determinada, seguindo-se os breakpoints propostos pelo Clinical and Laboratory Standard Institute (CLSI). 
O método foi comparado com outros testes fenotípicos (diluição em ágar, disco-difusão com cefoxitina) e com a detecção do gene $m e c A$ por reação da polimerase em cadeia (PCR). O novo método foi capaz de detectar resistência à oxacilina em $S$. aureus e ECN quando outros métodos fenotípicos falharam. A tipagem genotípica do operon mec nas sete linhagens de estafilococos estudadas foi realizada por PCR e seqüenciamento, levando-se em consideração o tipo de complexo ccr e a classe do complexo mec. Das sete linhagens analisadas, três apresentaram $c c r$ tipo 3 e complexo mec classe A e quatro abrigavam $c c r$ tipo 2 e complexo mec classe B. Mutações, caracterizadas por troca de nucleotídeos, inserções e deleções foram encontradas nas linhagens analisadas. Na maioria das linhagens estudadas, as mutações não pareceram ter tido efeito no mecanismo de resistência, pois após pressão seletiva da oxacilina estas linhagens passaram a expressar resistência, exceto a linhagem $S$. aureus 112 que manteve o mesmo perfil inicial de sensibilidade após cultivo na presença de oxacilina. Também foi possível avaliar que a indução do operon $m e c$, re- presentada pela detecção fenotípica da resistência, ocorreu nas linhagens de estafilococos com deleção do gene $m e c R 1$, cujo produto tem sido mostrado como indutor deste operon. Outro possível indutor do operon mec, o produto do gene blaRl, estava presente nas linhagens e pode ter feito esta função. Das seis linhagens de SHN analisadas, cinco apresentaram padrão de multirresistência a antibióticos, incluindo resistência à oxacilina, novobiocina e vancomicina, e uma contrariou este padrão e foi resistente somente à penicilina e à novobiocina. $\mathrm{O}$ perfil de pulsed-field gel electrophoresis (PFGE) indicou que cinco linhagens de SHN pertenciam ao mesmo clone e abrigavam o mesmo tipo de elemento SCCmec (tipo III). A análise, por microscopia eletrônica de transmissão, das cinco linhagens de SHN que apresentaram resistência à vancomicina indicou que o espessamento da parede celular estava envolvido nesta resistência. A identificação desta subspécie como causa de infecções hospitalares é de grande importância devido ao padrão de multirresistência a antibióticos que, frequentemente, a acompanha.

\section{INVESTIGAÇÃO SOBRE ELEMENTOS ENVOLVIIDOS NO CONTROLE DE EXPRESSÃO GÊNICA EM Leishmania : OS GENES DAS FOSFOGLICERATO-QUINASES COMO MODELO}

\author{
Aline de Azevedo \\ Orientadora: Profa. Dra. Angela Kaysel Cruz \\ Tese de Doutorado apresentada em 18/09/2008
}

Nosso objetivo central foi estudar o controle de expressão dos genes que codificam as isoformas citosólica (PGKB) e glicossômica (PGKC) da fosfoglicerato quinase de Leishmania major. Em estudo anterior mostramos que transfectantes supe-expressores de PGKC apresentavam um número baixo de cópias do plasmídeo e de seus transcritos quando comparado aos transfectantes super-expressores da isoforma citosólica (PGKB) e controles. Paradoxalmente, a quantidade de proteínas, avaliada por imunodetecção, não mantém correlação com os níveis dos transcritos. Esses dados nos deram suporte para investigar a existência de elementos controladores de replicação, transcrição e/ou tradução do plasmídeo. Tendo como hipótese que as regiões 5' ou 3' não traduzidas (UTRs) do PGKC poderiam estar envolvidas no controle de expressão desse gene, construímos dois recombinantes quiméricos portando a região $5^{\prime}$ de um dos PGKs ligada à região. 3' do outro e vice-versa. As quimeras foram transfectadas em L. major e caracterizadas quan- to ao comportamento em cultura, número de cópias do plasmídeo, nível e estabilidade do transcrito e nível e estabilidade da proteína. Nossos resultados indicam que é necessária a presença concomitante das 5' e 3' UTRs do PGKC para manter baixo o número de cópias do recombinante, baixos níveis de transcrito e alta a estabilidade do transcrito nos transfectantes estudados. A maior estabilidade do transcrito PGKC deve contribuir para a maior abundância da proteína compartimentalizada no glicossomo, sem qualquer contribuição da estabilidade da proteína compartimentalizada, que é inferior à da isoforma citosólica. Além disso, para investigarmos se as regiões flanqueadoras do PGKC atuam controlando a expressão de outros genes que não estejam envolvidos na via glicolítica e que não sejam endereçados ao glicossomo, geramos um recombinante no qual o gene que codifica a higromicina fosfotransferase (HFT) foi inserido em fase de leitura com o PGKC, em sua porção central. Estes recombinantes foram transfectados em L. major e caracterizados quanto aos mesmos parâmetros. Observamos que o controle sobre o número de cópias do plasmídeo é perdido, mas o nível do transcrito ectópico e sua estabilidade assemelham-no ao transcrito PGKC original. 


\section{GERAÇÃO DE MUTANTES DE Leishmania ssp SUPEREXPRESSORES CONSTITUTIVOS DE GENE REPÓRTER : FERRAPENTAS ÚTEIS PARA A VARREDURA DE NOVAS DROGAS}

\section{Mônica Cristina Terrão}

Orientadora: Profa. Dra. Angela Kaysel Cruz

Dissertação de Mestrado apresentada em 18/09/2008

O parasito Leishmania é o agente etiológico das leishmanioses, doença endêmica que representa sério risco para um décimo da população mundial. Não existindo vacina, o tratamento é realizado por administração de compostos que apresentam alto nível de toxicidade. Neste contexto, este trabalho teve como objetivo a criação de uma linhagem de Leishmania que possa ser utilizada na busca de novos compostos com ação leishmanicida.

Genes de resistência a drogas utilizados na seleção de transfectantes podem interferir nas análises de diferentes compostos em teste, por isso, construímos cassetes portando genes repórteres sem marcador de seleção que foram transfectados em Leishmania, para serem incorporados no lócus do RNA ribossômico, sob controle do único promotor forte de Leishmania, que dirige a transcrição constitutiva de genes.

Inicialmente modificamos vetores disponíveis portando o gene da proteína fluorescente verde $(G F p)$ e dele extraímos o marcador de seleção. Testamos diferentes técnicas para seleção dos transfectantes com base na fluorescência: (i) separação das células fluorescentes em FACs; (ii) diluição limitante associada à análise em fluorímetros ou microscópio de fluorescência; (iii) co-transfecção com um plasmídeo circular portando o marcador de seleção e um fragmento linear portando o gene da GFP para inserção no lócus ribossômico. Entretanto, a baixa eficiência de transfecção não permitiu a recuperação de transfectantes em nenhuma das estratégias. Por isso, decidimos gerar construções que permitissem transfecção em etapas consecutivas (com marcadores de seleção positivo e negativo) para recuperar transfectantes que carregasse somente o gene repórter. A primeira transfecção foi feita com a utilização de um cassete que continha o gene da higromicina fosfotransferase (HYG), o gene da timidina kinase de HSV-1, e o gene repórter flanqueados pelas regiões de homologia com o lócus ribossômico. A seleção dos transfectantes positivos foi realizada na presença de higromicina $\mathrm{B}$. Um segundo cassete contendo somente o gene repórter flanqueado pelas regiões de homologia com o genoma foi transfectado nos mutantes portando o primeiro cassete. A seleção foi feita pela utilização de ganciclovir, e a expressão da SEAP foi confirmada por luminometria. Os vários plasmídeos construídos nesse trabalho poderão ser instrumentos úteis para diversas aplicações. Mais importante, os mutantes de Leishmania resultantes da primeira transfecção são uma ferramenta poderosa para a inserção de qualquer gene de interesse, sem a interferência de genes de resistência.

\section{ANÁLISE FUNCIONAL E CARACTERIZAÇAO DO GENE LMF23.0310 DE LEISHMANIA MAJOR PRESENTE EM UMA REGIÃO AMPLIFICÁVEL EM RESPOSTA À PRESSÃO POR DROGAS}

\section{Marlei Josiele Augusto \\ Orientador: Prof. Dr. Luiz Ricardo Orsini Tosi}

Tese de Doutorado apresentada em 26/09/2008

O fenômeno de amplificação gênica é um mecanismo de autopreservação celular observado com freqüência no protozoário parasita Leishmania, quando submetido a estímulos negativos como, por exemplo, presença de drogas. O lócus $\mathrm{H}$ codifica genes envolvidos em mecanismos diversos de resistência a drogas. Este lócus também codifica outros genes de função desconhecida. O objetivo deste trabalho foi caracterizar a função de um gene de função desconhecida, Lmjf23.031 O(ORF5).

Para tanto, utilizamos linhagens mutantes do parasito geradas pela recombinação homóloga de fragmentos de nocaute do gene específico. Os fragmentos foram isolados de um vetor albergando o gene interrompido pela inserção do transposon /NEO*SA T.

A utilização do fragmento nocaute ORF5::/ NEO*SAT, que contém um transposon com um gene repórter (NEO) possibilitou não apenas o estudo do efeito de ruptura do gene alvo, mas também a caracterização da proteína de fusão expressa a partir do contexto cromossômico.

Além do gene repórter, o transposon possui uma marca de seleção SAT, gene que expressa resistência a nourseotricina. A caracterização fenotípica e a investigação da presença e do nível de transcritos originados a partir da expressão da marca de seleção (SAT) no contexto cromossomal nos mutantes heterozigotos permitiram iniciar o estudo do efeito do contexto genômico na expressão de genes. 


\section{BIOQUÍMICA}

\section{ESTUDO DOS PADRÕES DE ANSIEDADE DE CAMUNDONGOS E OS EFEITOS DO ESTRESSE NA RESPOSTA HORMONAL E FUNÇÕES EFETORAS DE MACRÓFAGOS}

\author{
Andréia Akemi Suzukawa \\ Orientador: Prof. Dr. Bernardo Mantovani \\ Dissertação de Mestrado apresentada em 14/07/2008
}

Diversos estudos têm descrito como o estresse pode levar ao comportamento de ansiedade, mas pouco se conhece sobre como a ansiedade pode alterar a resposta ao estresse. Existe uma comunicação bidirecional entre os sistemas neuroendócrino e imune, mas os relatos descrevendo estas interações são controversos. Neste estudo, investigamos a influência da ansiedade na resposta ao estresse agudo pelo frio, pela avaliação da liberação hormonal e das funções efetoras de macrófagos. Os animais foram classificados como ansiosos e não-ansiosos pelo método do labirinto em cruz elevado. Observamos que em relação (a) à liberação dos hormônios plasmáticos após o estresse, houve um aumento da corticosterona e catecolaminas em camundongos não- ansiosos, mas não nos ansiosos. A administração de LPS atuou como um estressor para os animais não-ansiosos e aumentou a responsividade dos ansiosos, nos quais observamos um aumento da liberação desses hormônios após estresse; (b) à fagocitose de timócitos apoptóticos, o estresse teve um efeito supressor em macrófagos residentes ou ativados por LPS, de animais ansiosos, mas não em não-ansiosos. $\mathrm{O}$ estresse diminuiu também a fagocitose por macrófagos ativados por LPS e mediada por FcyR, em animais ansiosos. Macrófagos residentes de animais não-ansiosos fagocitaram menos zymosan que os de ansiosos e, curiosamente, o inverso ocorreu para macrófagos ativados por LPS. O estresse diminuiu a fagocitose de zymosan por macrófagos de animais ansiosos, mas potencializou este fenômeno em macrófagos ativados por LPS. A fagocitose mediada pelo receptor de complemento foi modulada positivamente pelo estresse, independentemente do perfil de ansiedade; (c) à produção de espécies reativas de oxigênio, a cinética de liberação foi diferente entre os perfis de ansiedade. O pico da liberação espontânea de superóxido foi maior e mais rápido em animais ansiosos, em relação aos não-ansiosos. O estresse diminuiu o tempo do pico de liberação de superóxido, tanto basal quanto estimulada via Fc $\gamma \mathrm{R}$ nos macrófagos ativados de animais não-ansiosos. A partir destes resultados, concluímos que a resposta ao estresse pode variar dependendo do padrão comportamental do indivíduo e pode ser modificada pela presença de uma inflamação. Todos esses fatores, em conjunto, podem modular o sistema imune, levando a diferentes efeitos, dependendo do estado de ativação da célula analisada e do tipo de receptores envolvidos.

\section{PURIFICAÇÃO E CARACTERIZAÇÃO DE UMA PROTEÍNA ANGIOGÊNICA, INDUTORA DE FIBROPLASIA E CICATRIZANTE PRESENTE NO LÁTEX NATURAL DA SERINGUEIRA Havea brasiliensis}

\section{Ricardo Jose de Mendonça}

Orientador: Prof. Dr. Joaquim Coutinho-Netto

Tese de Doutorado apresentada em 08/08/2008

Vários trabalhos têm sugerido que o látex natural, extraído da seringueira Hevea brasiliensis possui atividade angiogênica e aceleradora do processo cicatricial. Desta forma, o estudo de uma proteína capaz de interagir com estes processos, presente no látex, é de grande importância para o desenvolvimento de novas formulações farmacêuticas aplicadas, principalmente, na cicatrização de feridas crônicas. Este trabalho, utilizando-se de metodologias tradicionais de purificação de proteínas por cromatografia e eletroforese em conjunto com a caracterização de ativida- des ligadas ao processo de cicatrização (ensaios in vivo e in vitro) permitiu o isolamento de uma proteína angiogênica, com alto grau de homogeneidade. A primeira etapa de purificação selecionou uma fração, aqui denominada FrHB, 1 indutora do aumento da permeabilidade vascular, angiogênica, aceleradora do processo cicatricial, proliferadora celular da linhagem Hek293T e reativa com o anticorpo policlonal anti- FGFb. O estudo desta fração por eletroforese bidimensional e espectrometria de massa mostrou 11 spots que, apesar de limitado pelo baixo número de proteínas de origem vegetal depositados nos atuais bancos de dados públicos, permitiu a identificação de uma chaperonina de $60 \mathrm{KDa}$ que, de acordo com a literatura, pode intervir junto ao processo inflamatório. A seqüência de purificação con- 
tou com a eficiência cromatográfica conseguida pela metodologia HPLC, o que permitiu a separação de uma proteína de $-20 \mathrm{KDa}$, constituída de 2 cadeias polipetídicas unidas por pontes dissulfeto, PI -5,3 que apresenta grande atividade angiogênica na MCA. Em conjunto, estes resultados apoiam a participação desta proteína na aceleração do processo cicatricial observado em estudos clínicos realizados com biomembrana de látex natural.

\title{
PAPEL DO ESTRESSE NA REATIVIDADE DE CAMUNDONGOS À INFECÇÃO POR Leishmania major
}

\section{Andressa Rodrigues de Souza}

Orientador: Prof. Dr. Francisco Juarez Ramalho

Dissertação de Mestrado apresentada em 29/08/2008

O estresse crônico afeta significativamente a função do sistema imune, assim como modifica a evolução de uma variedade de doenças infecciosas. Neste estudo tivemos por objetivo investigar o papel do estresse crônico no modelo de resistência/susceptibilidade à infecção por Leishmania major em camundongos isogênicos e, paralelamente, avaliar possíveis diferenças entre machos e fêmeas na reatividade ao estresse. Nossos dados sugerem que o estresse crônico repetitivo, por isolamento social, não induz uma alteração uniforme no tamanho das lesões cutâneas leishmanióticas de camundongos C57BL/6 de ambos os sexos. Por outro lado, quando camundongos tanto da linhagem C57BL/6, quanto da linhagem BALB/c, foram submetidos ao estresse crônico imprevisível (aleatório), verificou- se um aumento significativo das lesões cutâneas de machos e fêmeas C57BL/6, bem como de machos BALB/c. Ao final do curso da infecção e indução de estresse, os níveis plasmáticos do hormônio corticosterona apresentaram-se elevados apenas nas fêmeas da linhagem C57BL/6 e nos machos da linhagem BALB/c. Além desses parâmetros avaliados, a quantificação da carga parasitária no local da infecção, em animais BALB/c, evidenciou a presença de um número maior de parasitas nas lesões, tanto nos machos como nas fêmeas submetidos ao estresse. Apesar desse aumento do número de parasitas em animais de ambos os sexos, apenas nos machos da linhagem BALB/c foi detectada diminuição na produção de óxido nítrico por macrófagos do peritônio. Nos camundongos machos dessa linhagem, após o estresse crônico aleatório, a produção das citocinas IFN- $\gamma$, IL-4 e IL-5 também foi alterada, com discreta diminuição na concentração de $1 \mathrm{FN}-\gamma$ e aumento dos níveis de IL-4 e IL-5. Um fato a ser notado, é que camundongos $\mathrm{BALB} / \mathrm{c}$ machos apresentaram menor ganho de massa corporal, não só quando foram infectados e estressados, mas também quando foram apenas infectados, em relação aos animais saudáveis. Em conjunto, esses dados sugerem que as fêmeas da linhagem C57BL/6 são mais susceptíveis à infecção por L. major que os machos, além de apresentarem maior sensibilidade a eventos estressantes crônicos. Nos camundongos da linhagem BALB/c, apesar das fêmeas apresentarem lesões de patas mais evidentes que os machos, essa diferença entre os sexos toma-se praticamente inexistente quando os animais são submetidos ao estresse crônico aleatório, possivelmente pela maior sensibilidade dos machos a esse estresse.

\section{CLÍNICA CIRÚRGICA}

\begin{abstract}
ASTROCITOMA PILOCÍTICO: ESTUDO CLINICOPATOLÓGICO COM AVALIAÇÃO DE PROLIFERAÇÃO CELULAR, EXPRESSÃO DE GALECTINA-3, DENSIDADE VASCULAR E DIFERENCIAÇÃ̃O NEURONAL
\end{abstract}

\author{
Aline Nazareth Paiva Paixão Becker \\ Orientador: Prof. Dr. Ricardo dos Santos \\ Dissertação de Mestrado apresentada em 16/08/2008 \\ Tumores primários do sistema nervoso central são a \\ segunda neoplasia mais freqüente na infância. $\mathrm{O}$ astrocitoma
}

pilocítico é o glioma mais comum desta faixa etária, com pico de incidência na primeira década de vida, sem predileção por sexo. Ocorre ao longo do neuroeixo, com sintomatologia dependente da localização da lesão. Os principais marcadores histológicos são: padrão bifásico, fibras de Rosenthal e corpos granulares eosinofílicos. 
Atividade mitótica, proliferação microvascular e necrose podem estar presentes e não traduzem malignidade. Geralmente são neoplasias indolentes, passíveis de cura após ressecção total, porém algumas lesões cursam com evoluções adversas, em intervalos de tempo variáveis. Não foram descritos fatores prognósticos clínicos, histopatológicos ou imuno-histoquímicos. O presente estudo visou comparar a sobrevida média e a evolução clínica dos pacientes com astrocitomas pilocíticos localizados em áreas eloqüentes e não eloqüentes do sistema nervoso central, buscando identificar fatores clínico-cirúrgicos, histopatológicos e/ou imuno-histoquímicos que possam predizer o comportamento da neoplasia. Foi realizado estudo retrospectivo, de 1984 a 2006, observando dados clínicoepidemiológicos, características histológicas e imuno-histoquímicas com os marcadores Ki67, galectina-3, Neu N e CD31, sendo identificados 31 pacientes ( 15 do sexo masculino e 16 do sexo feminino), com idade média de 7,8 anos e tempo de seguimento de até 20 anos (mediana de 4 anos).

A maioria das lesões $(n=20)$ encontrava-se em áreas não-eloqüentes, sendo o cerebelo a localização mais freqüente. Durante o seguimento, a maioria dos pacientes apresentou evolução favorável (sem recidiva ou crescimento de lesão residual) ( $n=23$ ) e sem quaisquer sintomas no pós-operatório $(n=19)$. A localização mostrou-se importante por estar relacionada à possibilidade de ressecção total da lesão. Fibras de Rosenthal, corpos granulares eosinofílicos, proliferação microvascular e infiltrado linfocitário foram evidenciados em mais da metade dos casos. Alterações degenerativas foram observadas em menos de $1 / 3$ dos casos. A maioria dos casos apresentou predomínio de áreas frouxas e de padrão microcístico. Nenhuma variável histopatológica apresentou correlação significativa com evolução desfavorável; porém a ocorrência de sintomas no pósoperatório apresentou correlação positiva com padrão histológico frouxo.

Do mesmo modo, o índice de proliferação celular pelo Ki67, o padrão de marcação da galectina 3 e da Neu N e a densidade microvascular pelo CD31 não apresentaram correlação com a evolução clínica. A sobrevida média e a sobrevida livre de evento não foram influenciadas pelos fatores testados no estudo, confirmando que não há critérios clínicos, histopatológicos e imuno-histoquímicos que possam predizer com segurança o curso de um astrocitoma pilocítico.

\section{TRATAMENTO CIRÚRGICO DO TUMORES GLÔMICOS DO FORAME JUGULAR: PROPOSIÇÃO DE SITEMATIZAÇÃO DA VIA DE ACESSO EM RELAÇÃO AO NERVO FACIAL}

\section{Luis Alencar Biurrum Borba}

Orientador: Prof. Dr. Benedicto Oscar Colli

Tese de Doutorado apresentada em 21/08/2008

Introdução: Os tumores glômicos do forame jugular são tumores infrequientes na prática neurocirúrgica. A localização e padrão altamente vascularizado fazem com que esses tumores sejam de difícil tratamento cirúrgico. Após tentativas iniciais, o tratamento cirúrgico foi abandonado e substituído pelo tratamento radioterápico que foi ineficaz.

Durante décadas a abordagem cirúrgica era baseada em ampla exposição da área e associada à morbidade, principalmente paralisia facial periférica temporária, devida à necessidade sistemática de transposição anterior do nervo facial. Com o avanço dos conhecimentos anatômico e radiológico da região, as abordagens foram mais bem planejadas e tornaram o tratamento cirúrgico factível, associado à baixa morbidade e mortalidade. Este trabalho teve por objetivo analisar a extensão e as relações dos tumores glômicos no osso temporal e o resultado do seu tratamento cirúrgico visando à preservação do nervo facial, com base nas suas extensões e relação com o nervo facial e propor uma sistematização das suas abordagens.

Material e Métodos: No período de dezembro de 1997 a maio de 2007 foram operados pelo autor 34 pacientes portadores de tumores glômicos do forame jugular. Doze pacientes eram do sexo masculino e 22 feminino. Os principais sinais e sintomas foram perda auditiva em $88 \%$, disfunção da deglutição e fonação em $50 \%$ e paresia facial periférica em $41 \%$ dos pacientes. A Ressonância Magnética (RM) demonstrou tumor localizado no forame jugular em todos os pacientes, extensão para a orelha média em $97 \%$, cervical em $85 \%$ e intradural em $41 \%$ dos pacientes. A angiografia demonstrou vascularização tumoral através de ramos da artéria carótida externa (ACE) em todos os pacientes, da artéria carótida interna (ACI) em $44 \%$ e da artéria vertebral (AV) em $32 \%$ dos pacientes.

A técnica cirúrgica utilizada variou conforme as características de cada caso e classificada em 4 tipos. A) Abordagem infralabirintica retrofacial (32,5\%); B) Abordagem infralabiríntica pré e retrofacial sem oclusão do meato acústico externo (20,5\%); C) Abordagem infralabiríntica pré e retrofacial com oclusão do meato acústico externo (41\%); D) Abordagem infralabiríntica com transposição anterior do nervo facial, oclusão do meato acústico externo e remoção das estruturas da orelha média (6\%).

Resultados: Em 91\% dos pacientes foi realizada a remoção cirúrgica radical do tumor e em $9 \%$ dos pacientes foi realizada a remoção parcial. Dos 21 pacientes sem disfunção do nervo facial no período pré-operatório, em 20 (95\%) o nervo foi mantido em posição anatômica, sendo 
que em 17 (85\%) foi mantida a função grau 1 de House e Brackmann (H\&B). Três pacientes apresentaram no pósimediato graus 2,3 e 4 de H\&B. Seis pacientes apresentaram novos déficits dos nervos cranianos baixos $(17,6 \%)$ no pósoperatório, sendo que cinco $(83 \%)$ foram submetidos a embolização pré-operatória.

Fístula liquórica ocorreu em $17,6 \%$ dos casos. A recuperação funcional global utilizando a escala de Karnofski foi: 100 em cinco pacientes (15\%), 90 em 15 (45\%), 80 em 11 (33\%) e 70 em dois (6\%). A recuperação da função de de- glutição foi total em todos os casos, no entanto, todos persistem com distúrbio da fonação. Um paciente foi a óbito secundário a broncopneumonia aspirativa.

Conclusões: Independentemente do tamanho do tumor e sua extensão é possível a remoção total sem a transposição anterior definitiva do nervo facial, com baixa morbidade e excelente resultado funcional do nervo facial. A sistematização das vias de acesso em relação ao nervo facial apresentada nesse trabalho facilita a remoção do tumor diminuindo a morbidade trans-operatória e pós-operatória.

\section{ANÁLISE DO EFLUENTE HEPÁTICO COMO VALOR PREDITIVO DA QUALIDADE DO ENXER- TO NO TRANSPLANTE DE FÍGADO}

\section{Eduardo Garcia Pacheco}

Orientador: Prof. Dr. Orlando de Castro e Silva Jr

Tese de Doutorado apresentada em 05/09/2008

O termo efluente hepático é o nome dado à solução coletada da veia cava infrahepática durante a lavagem do enxerto no transplante de fígado, antes da reperfusão do mesmo, com o intuito de extrair o excesso da solução de preservação e seus componentes. Essa lavagem é um procedimento necessário e inerente ao transplante. Nessa solução são encontrados produtos da degradação celular e endotelial, decorrentes da lesão de preservação do enxerto durante o período de isquemia. $\mathrm{O}$ presente trabalho tem como objetivo, avaliar o valor das substâncias dosadas no efluente hepático como um indicador precoce da qualidade e da evolução do enxerto no transplante ortotópico do fígado e considerá-lo como mais um marcador do grau da lesão de preservação. Foram dosadas as enzimas hepáticas dos efluentes de 47 enxertos de transplantes ortotópico de fígado de doadores cadáveres. Tais enzimas foram comparadas com os níveis séricos das mesmas no receptor durante o pós-operatório e divididas em dois grupos: vivos (Grupa A) e óbitos (Grupo B). Os níveis séricos e no efluente das substâncias dosadas no grupo $\mathrm{B}$, foram significantemente maiores do que no grupo $\mathrm{A}(\mathrm{P}<0,05)$ com uma correlação positiva e significativa entre mesmo. O efluente hepático, portanto, pode ser considerado um bom marcador da qualidade do enxerto e do grau de lesão de preservação do fígado transplantado e predizer a tendência evolutiva do paciente submetido ao transplante de fígado.

\section{EXPRESSÃO DO MRNA DOS RECEPTORES NMDA (NR1, NR2A E NR2N) E GABAA ( 1 1, $\beta 1$ E ß2) EM AMÍGDALAS DE PACIENTES COM EPILEPSIA DO LOBO TEMPORAL MESIAL}

\section{José Carlos de Moura}

Orientador: Prof. Dr. Carlos G. Carlotti Jr.

Tese de Doutorado apresentada em 11/09/2008

Introdução: O complexo amigdalóide é conhecido por mediar os componentes emocionais, do comportamento e da memória e estar criticamente envolvido nas síndromes neurológicas, como: epilepsia do lobo temporal, síndrome do estresse pós-trauma e depressão. Dentro do complexo amigdalóide, o núcleo lateral representa a maior estação de informações recíprocas com as áreas corticais e subcorticais. Alguns estudos foram realizados em amígdalas de animais experimentais, porém pouco se conhece sobre a fisiopatologia da amígdala humana, nas crises convulsivas e em especial nas avaliações de possíveis alterações em seus neurotransmissores.
Objetivo: Visando o melhor entendimento desta patologia nós estudamos o perfil de expressão das subunidades dos receptores dos neurotransmissores NMDA (NR1, NR2A, NR2B) e GABAA (k1, $\beta 1, \beta 2)$ em amígdalas de pacientes operados de epilepsia do lobo temporal mesial, refratária a medicação, comparados com controle e com parâmetros clínicos.

Material e Método: A pesquisa foi aprovada pela comissão de Ética em Pesquisa do Hospital das Clínicas da Faculdade de Medicina de Ribeirão Preto-SP

(Processo no. 5864/05). Avaliamos a expressão das subunidades dos receptores

dos neurotransmissores da GABAA $(\mathrm{k} 1, \beta 1, \beta 2)$ e NMDA (NR1, NR2A, NR2B) em 27 amígdalas de pacientes operados de epilepsia do lobo temporal. Também foi realizada a mesma análise em 14 peças de necropsias de pacien- 
tes não neurológicos ou psiquiátricos. Estas dosagens foram realizadas pelo método de PCR em tempo real. Foi feita correlação com os parâmetros clínicos e análise estatística.

Resultados: Verificamos diferença estatisticamente significante com o aumento da expressão da subunidade do receptor glutamatérgico NMDA NR1 ( $p=0,021)$ e tendência à aumento na expressão da subunidade GABAA $\beta 1$ $(\mathrm{p}=0,065)$ nas amígdalas de pacientes com epilepsia do lobo temporal quando comparados como controle. Constatamos tendência a aumento das subunidades NMDA NR1 $(\mathrm{p}=0,100)$ e NMDA NR2B $(\mathrm{p}=0,110)$ nas amígdalas de pacientes com epilepsias parciais quando comparadas com pacientes com epilepsias generalizadas secundariamente.

Conclusão: Nós observamos que existe aumento da subunidade NMDA NR1 nas amígdalas de pacientes com crises convulsivas do lobo temporal mesial. Existe tendência à elevação dos valores da subunidade do receptor GABA $\beta 1$ nos pacientes epilépticos. Existe também tendência à aumento dos valores das subunidades de NMDA NR1 e NMDA NR2B nos pacientes com crises convulsivas parciais em relação aos pacientes com convulsões com generalização secundária.

\section{CLÍNICA MÉDICA}

\section{IDENTIFICAÇÃO E CARACTERIZAÇÃO DE MUTAÇÕES GERMINATIVAS NO GENE VHL EM FAMÍLIAS COM A DOENÇA DE VON HIPPEL-LINDAU}

\section{Israel Gomy}

Orientador: Prof. Dr. Wilson Araujo da Silva Junior

Dissertação de Mestrado apresentada em 02/7/2008

A doença de von Hippel-Lindau (VHL) é uma síndrome de câncer familial herdada de forma autossômica dominante que predispõe ao desenvolvimento de diversos tipos de neoplasias benignas e malignas. É causada por mutações germinativas e somáticas no gene $V H L$ e tem uma incidência aproximada de um a cada 36.000 nascimentos. $\mathrm{O}$ gene $V H L$ é um supressor tumoral e codifica a proteína VHL, a qual possui, entre outras funções, uma atividade ubiquitina-ligase, responsável pela poliubiquitinização e degradação proteassômica da subunidade alfa do fator induzido por hipóxia (HIF1-k) na presença de oxigênio. As principais características da doença de VHL são: hemangioblastomas de sistema nervoso central (SNC), principalmente do cerebelo e medula espinhal; angiomas de retina e carcinoma renal de células claras. A probabilidade de desenvolver cada um desses tumores ao longo da vida é estimada em maior que $70 \%$, podendo manifestar-se desde a infância até a fase adulta, principalmente entre a $2^{\mathrm{a}}$ e $3^{\mathrm{a}}$ décadas de vida. Classifica-se a doença de VHL conforme a ausência (tipo 1) ou presença de feocromocitoma (tipo 2). A doença do tipo 2 é causada, essencialmente, por mutações missense no gene $V H L$. As mutações podem ser grandes deleções (20\%) ou pontuais (80\%) do tipo missense, frameshift, nonsense ou em regiões de splicing. O teste genético é considerado padrão para o manejo clínico dos pacientes e dos familiares em risco, pois permite o diagnós- tico e o tratamento precoce das neoplasias, melhorando assim a expectativa de vida. Técnicas de biologia molecular, como o seqüenciamento direto do DNA e o Southern blotting quantitativo, permitem a detecção de mutações germinativas em até $100 \%$ dos casos. Técnicas mais recentes, como o PCR quantitativo em tempo real e o MLPA, têm sido empregadas para uma detecção mais eficaz de grandes deleções no gene VHL. Os objetivos do presente estudo foram: (1) diagnosticar os pacientes com suspeita da doença de VHL; (2) identificar e caracterizar mutações germinativas pontuais no gene $V H L$ nos pacientes e em seus parentes de $1^{\circ}$ grau; (3) fornecer o aconselhamento genético pré e pós-teste. Dos 37 indivíduos com suspeita da doença de VHL, 14 pacientes de sete famílias diferentes preencheram os critérios diagnósticos. Um paciente apresentou hemangioblastoma cerebelar isolado e sete parentes de $1^{\circ}$ grau estavam assintomáticos. Foram realizadas as técnicas de PCR, RFLP e seqüenciamento direto do DNA genômico e após clonagem. Foram identificadas quatro mutações pontuais na região codificadora do gene $V H L$ em quatro famílias diferentes, sendo que duas delas haviam sido descritas na literatura [c.226_228delTTC (F76del), c.217C > T $(\mathrm{Q} 73 \mathrm{X})]$. As outras duas mutações são descritas pela primeira vez neste estudo e afetam o sitio de splicing (IVS1-1 G>A, IVS2-1 G>C). É provável que as demais três famílias sejam portadoras de deleções germinativas no gene $V H L$. Em resumo, os resultados apresentados neste estudo ampliam o conhecimento da base molecular da doença de VHL e consiste na primeira pesquisa de pós-graduação produzida pelo ambulatório de aconselhamento genético do câncer do HCFMRP-USP. 


\section{ESTUDO DO DESEMPENHO VENTRICULAR EM REPOUSO E DURANTE O EXERCÍCIO FÍSICO E CORRELAÇÃO COM A CAPACIDADE FUNCIONAL EM PACIENTES COM INSUFICIÊNCIA CARDÍACA}

\section{Ana Paula Manfio Pereira \\ Orientador: Prof. Dr. Marcus Vinícius Simões \\ Dissertação de Mestrado apresentada em 04/7/2008}

Embasamento racional: A gravidade da disfunção ventricular esquerda em repouso apresenta pobre correlação com os sintomas em pacientes com síndrome clínica de insuficiência cardíaca (IC). Por outro lado, a avaliação da reserva inotrópica ventricular esquerda sob estímulo de dobutamina tem demonstrado boa correlação com a capacidade funcional, constituindo-se importante determinante prognóstico e preditor de resposta a intervenções terapêuticas nesses pacientes. Ainda é controverso se a reserva inotrópica elicitada pelo exercício físico detém as mesmas correlações com a capacidade funcional, particularmente em pacientes em uso crônico de agentes bloqueadores betaadrenérgicos.

Objetivos: A presente investigação teve como objetivos principais: a) Utilizar a ventriculografia nuclear (VN) para investigar a função ventricular em repouso e durante exercício físico em pacientes com IC em uso de agente bloqueador beta-adrenérgico em comparação com indivíduos controles normais; b) Correlacionar os resultados com os parâmetros de avaliação funcional obtidos durante o teste cardiopulmonar (TCP).

Métodos: Foram investigados 14 portadores de IC, de ambos os gêneros ( 5 homens), idade de $53 \pm$ 9,6 anos, fração de ejeção do ventrículo esquerdo (FEVE) em repouso de $34,7 \pm 10,6 \%$, estáveis clinicamente sob uso de terapêutica medicamentosa otimizada e 17 controles saudáveis pareados por gênero e idade ( $52 \pm 10,2$ anos) em relação ao grupo IC. Os indivíduos foram submetidos à VN realizada com ${ }^{99 \mathrm{~m}} \mathrm{Tc}$ pela técnica de equilíbrio em repouso e durante exercício físico dinâmico em cicloergômetro. Utilizou-se cargas incrementais de 3 minutos, aquisição das imagens cintilográficas do compartimento sangüíneo sincronizadas pelo eletrocardiograma nos 2 minutos finais de cada estágio. A análise das imagens, na condição de repouso e pico do exercício, incluiu o cálculo da fração de ejeção do ventrículo esquerdo (FEVE), da velocidade máxima de enchimento (VMEnch) e esvaziamento do ventrículo esquerdo (VMEsv), dos índices de volume diastólico $\left(\mathrm{VDF}_{\mathrm{i}}\right)$ e sistólico $\left(\mathrm{VSF}_{\mathrm{i}}\right)$ finais, do volume de ejeção sistólica $\left(\mathrm{VES}_{\mathrm{i}}\right)$ e do índice de débito cardíaco $\left(\mathrm{DC}_{\mathrm{i}}\right)$. Calculou-se ainda as relações pico/basal (r) destes parâmetros. O TCP foi reali- zado em cicloergômetro com aplicação de carga tipo rampa, com análise das variáveis ventilatórias: consumo de oxigênio $\left(\mathrm{VO}_{2}\right)$, equivalentes ventilatórios do oxigênio $\left(\mathrm{VE} / \mathrm{VO}_{2}\right)$ e do dióxido de carbono $\left(\mathrm{VE} / \mathrm{VCO}_{2}\right)$. As variáveis de desempenho ventricular esquerdo durante esforço obtidos na $\mathrm{VN}$ foram analisadas em relação ao $\mathrm{VO}_{2}$ no limiar anaeróbico e no pico do exercício.

Resultados: Os pacientes do grupo IC demonstraram variáveis de desempenho ventricular esquerdo em repouso significativamente reduzidas quando comparadas aos controles: FEVE, VMEnch e VMEsv, p<0,001. A reserva inotrópica do ventrículo esquerdo ao esforço (aumento de pelo menos cinco unidades ejetivas) foi detectada em $42,8 \%$ do pacientes com IC. No pico do esforço, observou-se uma menor relação de aumento pico/basal do DCi nos pacientes com IC (1,74 $\pm 0,3)$ em comparação com os controles $(2,65 \pm$ $0,7), p<0,001$. Da mesma forma o VESi só exibiu aumento significativo nos controles. Não foram observadas diferenças entre os grupos quanto à variação nos valores de $\mathrm{VDF}_{\mathrm{i}}$ e VSFi. No teste cardiopulmonar, os portadores de IC apresentaram em relação aos controles, menores valores de $\mathrm{VO}_{2}$ no limiar anaeróbico $(10,22 \pm 1,8$ e 15,23 $\pm 4,6, \mathrm{p}=0,001)$ e no pico do exercício $(13,87 \pm 2,8$ e 29,32 $\pm 1,5$, p $<0,001)$, assim como o pulso de oxigênio $\left(\mathrm{VO}_{2} / \mathrm{FC}\right)$ pico $(8,72 \pm 3,1$ e 12,95 $\pm 4,9, \mathrm{p}=0,007)$, respectivamente. Da mesma forma o VE/ $\mathrm{VCO}_{2}$ foi significativamente maior no grupo IC $(\mathrm{p}=0,003) . \mathrm{O}$ $\mathrm{VO}_{2}$ no limiar anaeróbico correlacionou-se forte e significativamente com a reserva cronotrópica no grupo IC e controle $(\mathrm{r}=0,625, \mathrm{p}=0,016$ e $\mathrm{r}=0,760, \mathrm{p}=0,001$, respectivamente), contudo, correlação entre o $\mathrm{VO}_{2}$ pico e a reserva cronotrópica ao esforço foi observada apenas no grupo controle ( $\mathrm{r}=0,771, \mathrm{p}$ 0,001).

Conclusões: $\mathrm{O}$ presente estudo demonstrou que pacientes com IC beta-bloqueados submetidos à ventriculografia nuclear de esforço apresentaram em relação aos controles normais: a) menor reserva inotrópica do ventrículo esquerdo; b) reduzida reserva cronotrópica; c) ausência de variação significativa dos $\mathrm{VDF}_{\mathrm{i}}, \mathrm{VSF}_{\mathrm{i}}$ e do $\mathrm{VES}_{\mathrm{i}}$; d) incremento acentuadamente menor das VMEnch e VMEsv no pico do esforço. Nos portadores de IC a reserva inotrópica do ventrículo esquerdo não manteve correlação significativa com a capacidade funcional avaliada pelo teste cardiopulmonar; assim como não foi observada correlação entre a reserva cronotrópica e o grau de capacidade funcional pico no teste no teste cardiopulmonar. 


\section{ANÁLISES in vitro DE UM NOVO ANTICORPO BI-ESPECÍFICO BI20 (CD20XCD3) EM DIFEREN- TES NEOPLASIAS LINFÓIDES DE CÉLULAS B}

\author{
Otoni Flávio Andrada Veríssimo \\ Orientadora: Profa. Dra. Belinda Pinto Simões \\ Dissertação de Mestrado apresentada em 07/07/2008
}

Neoplasias linfóides B constituem um grupo heterogêneo de neoplasias. Constituem as neoplasias hematológicas mais freqüentes. Nos últimos anos poucos avanços foram feitos no que diz respeito ao tratamento destas doenças. O uso de anticorpos monoclonais e o transplante alogênico de medula óssea têm sido os únicos tratamentos que mostraram algum impacto em sua terapia. Bi20 (CD20xCD3), anticorpo monoclonal bi-específico, consiste da combinação de uma imunoglobulina de camundongo G2a (lgG2a) e IgG2b de rato, e é capaz de se ligar simultaneamente às células $\mathrm{T}$ (CD3) e as células $\mathrm{B}$ (CD20), facilitando o re-direcionamento das primeiras para junto das células $\mathrm{B}$ tumorais, proporcionando um aumento da citotoxicidade celular, fornecendo uma possibilidade para abordagem imunoterápica. Nossos objetivos foram analisar o efeito do Bi20 sobre a expressão de moléculas de co-estimulação (CD40, CD80 e CD86) nessas células e a indução de apoptose de linfócito T e B após exposição ao Bi20. Foram incluídas 21 amostras de sangue periférico de pacientes com neoplasias de células B. Após um período de incuba- ção de $72 \mathrm{~h}$ em cultura celular autóloga com células do paciente (Auto) e alogênica com células do paciente e doadores saudáveis (Alo), tratadas ou não com o Bi20, foi realizada a determinação de expressão das moléculas de co-estimulação e análise das sub-populações linfocitárias pré e pós tratamento por citometria de fluxo. Observou-se uma diminuição da percentagem de células B CD19+ tumorais confirmando dados já publicados. A ativação dos linfócitos $\mathrm{T}$ foi evidenciada pelo aumento de células CD3/HLA-DR+ sendo significativamente maior no Alo $+\mathrm{Bi} 20(\mathrm{p}<0,001)$. A fim de avaliar se a ativação excessiva poderia levar à apoptose das células $\mathrm{T}$ ensaios de apoptose foram realizados. Em 8 amostras nas sub-populações CD3+ demonstrando maior índice de apoptose nas culturas alogênicas tratadas com Bi20 corroborando com os dados de expressão de HLA-DR. A produção de citocinas evidenciou um aumento significativo de IFn e TNF nas amostras tratadas com Bi20. A produção de IL-10 ocorridas nas culturas alogênicas foi um achado inesperado. O uso de anticorpos especialmente bi-específicos no tratamento de neoplasias linfóides apesar de promissor deve ser levado para ensaios clínicos com muita cautela. Tanto a liberação excessiva de citocinas quanto a apoptose dos linfócitos $\mathrm{T}$ pode causar efeitos indesejados do ponto de vista clínico.

\section{QUESTIONÁRIO PARA DETECÇÃO DE ASMA RELACIONADA AO TRABALHO: AVALIAÇÃO DE SENSIBILIDADE E ESPECIFICIDADE}

\section{Roseane Durães Caldeira}

Orientador: Prof. Dr. Elcio dos Santos Oliveira Viana

Tese de Doutorado apresentada em 19/08/2008

A asma relacionada ao trabalho (ART) é considerada a doença respiratória ocupacional mais comum em muitos países industrializados e tem prevalência elevada. Apesar disso, muitos casos não são diagnosticados. Estudos têm demonstrado que ART pode resultar em sérias consequiências para saúde e sócio-econômicas. É caracterizada pela obstrução variável das vias aéreas e hiperreatividade brônquica causada pela exposição, no ambiente de trabalho, a poeiras, gases, vapores ou fumaça. Estima-se que em 3 a $21 \%$ dos casos de asma entre adultos, a asma é associada à exposição no ambiente de trabalho. Portanto, a identificação precoce é importante para melhorar a saúde e a qualidade de vida dos trabalhadores. Os objetivos gerais do presente estudo foram desenvolver e avaliar um questionário para triagem de indivíduos com suspeita dessa doença. $\mathrm{O}$ objetivo específico foi avaliar a sensibilidade e especificidade de cada questão para identificação das mais relevantes, ou seja, aquelas que melhor caracterizam o quadro de ART. Uma amostra de 174 indivíduos asmáticos e controles pre- encheram o questionário, mas 96 não completaram o protocolo devido asma grave ou devido impossibilidade de ter férias durante o estudo. Setenta e oito indivíduos se submeteram a espirometria, teste de broncoprovocação com metacolina e medidas de pico de fluxo expiratório, realizados em 2 períodos: trabalho e férias. Trinta e sete indivíduos foram diagnosticados como ART (grupo ART confirmada) e 41 indivíduos foram considerados grupo controle. A maioria das questões apresentou índice de reprodutibilidade Kappa satisfatório, de 0,8 a 1,0. Empregamos análise de regressão logística para identificar as respostas relacionadas ao diagnóstico confirmado. Presença de sibilos, dispnéia, perda da voz, espirros e asma no trabalho atual; mudança de emprego por razões de saúde; asma diagnosticada pelo médico; início dos sintomas na segunda - feira; asma na infância e trabalhar em ambiente fechado ou pouco ventilado ou em ambiente ventilado com ar condicionado, demonstraram associação com ART. Atribuindo um ponto a cada uma das questões ligadas a ART e criando um escore 0 a 10 pontos, observarmos que o escore $\geq 3$ pontos como valor de corte para definir questionário positivo gera sensibilidade de 0,9 e especificidade de 0,6 . Portanto, este questionário pode ser utilizado para identificar indivíduos com suspeita de ART. 


\section{ESTUDO DA DEGLUTIÇÃO EM PACIENTES COM MIOPATIA MITOCONDRIAL DO TIPO OFTAL- MOPLEGLIA EXTERNA CRÔNICA PROGRESSIVA: AVALIAÇÃO CLIINICA, MANOMÉTRICA E VIDEOFLUOROSCÓPICA}

\author{
Danielle Ramos Domenis \\ Orientador: Prof. Dr. Roberto Oliveira Dantas \\ Dissertação de Mestrado apresentada em 29/08/2008
}

As miopatias mitocondriais formam um grupo de desordens clinicamente heterogêneas que podem afetar múltiplos sistemas além do músculo esquelético. A oftalmoplegia externa crônica progressiva (CPEO) é um tipo de miopatia mitocondrial que tem como características alterações nos movimentos oculares, ptose, podendo ter acometimento da musculatura facial, além de atrofia muscular de membros. A fatigabilidade precoce pode ser a queixa principal e claramente desproporcional ao grau de fraqueza e atrofia muscular detectada. A disfagia na doença é uma manifestação descrita por muitos autores, porém pouco estudada ou caracterizada. O presente estudo teve como objetivo avaliar a deglutição de pacientes com miopatia mitocondrial do tipo CPEO através de avaliação clínica, manométrica e videofluoroscópica. Para tanto, foram selecionados 14 pacientes com diagnóstico de miopatia mitocondrial do tipo CPEO, em acompanhamento no Ambulatório de Doenças Neuromusculares do Hospital das Clínicas da Faculdade de Medicina de Ribeirão Preto da Universidade de São Paulo, independente de apresentarem queixas ou não quanto à alimentação. A idade variou de 15 a 62 anos, com idade média de 35,3 anos sendo 5 (35,7\%) do gênero masculino e $9(64,3 \%)$ do feminino. O grupo controle foi formado por 16 indivíduos saudáveis (sem doenças neurológicas ou queixas quanto à alimentação) com idade variando de 21 a 44 anos, idade média de 27,5 anos, sendo $6(37,5 \%)$ do gênero masculino e $10(62,5 \%)$ do feminino. Na avaliação clínica, além da anamnese, foi realizada avaliação estrutural e funcional da deglutição. Para isso foram utilizadas as consistências pastosa, líquida e sólida, em volume livre, conforme hábito do paciente. Na avaliação manométrica, as medidas foram feitas durante a deglutição líquida, para avaliar as pressões intraluminares no corpo do esôfago. Foram realizadas 10 deglutições com intervalo de 30 segundos entre elas e após cinco minutos de repouso mais 10 deglutições com intervalo de 10 segundos entre elas. Foram consideradas as medidas da pressão intraluminal, sua duração, área sob a curva e tempos parciais e totais de deslocamento da onda. Na avaliação videofluoroscópica utilizaram-se as dietas pastosa, líquida e sólida, sendo as duas primeiras em volume controlado de $5 \mathrm{ml}$. Para todas as consistências foram realizadas três ofertas, sendo que para o pastoso e sólido esse processo foi repetido. Além da dinâmica da deglutição na fase orofaríngea foram analisados os tempos de fase oral (TFO), depuração faríngea (DF), trânsito faríngeo (TF), trânsito pela transição faringoesofágica (TTFE) e tempo de movimentação hióidea (TMH). Em anamnese observamos que $9(64,3 \%)$ pacientes tinham queixas quanto a alimentação mas apenas 7 (50\%) apresentaram alterações na avaliação clínica, sendo essas alterações principalmente para as consistências pastosa $(57,1 \%)$ e sólida (100\%). As principais alterações foram fase oral prolongada, mastigação inadequada, deglutições múltiplas e fadiga. Na avaliação manométrica foi observado redução da motilidade esofágica sendo essa principalmente no esôfago proximal, com amplitude, duração e área sob a curva reduzidas. Quando comparado o desempenho do esôfago nos diferentes intervalos de deglutição, não houve relação com a presença da doença, pois a diferença foi significante tanto para os pacientes como para os controles. Na videofluoroscopia da deglutição, assim como na avaliação clínica, as principais alterações encontradas foram para as consistências pastosa e sólida, sendo elas tanto em fase oral como faríngea. Apesar disso não foi encontrado nenhum episódio de aspiração laringotraqueal. Quanto aos tempos de deglutição, apenas o TFO foi significantemente maior nos pacientes, sendo menor nos outros parâmetros como TF e TTFE. Ao compararmos as primeiras com as últimas deglutições para as consistências pastosa e sólida, verificamos que os pacientes apresentaram um aumento dos tempos de DF, TF, TTFE e TMH para a consistência sólida, sendo significante apenas para TF. O estudo permitiu concluir que pacientes com miopatia mitocondrial do tipo CPEO apresentam dificuldades de deglutição, com alterações orofaríngeas e esofágicas, sendo maiores para as consistências pastosa e sólida.

\section{AVALIAÇÃO DO ENVOLVIMENTO DE ALGUNS MECANISMOS FUNCIONAIS, INFLAMATÓ- RIOS E MORFOLÓGICOS NA FISIOPATOLOGIA DA EXCREÇÃO URINÁRIA DA $\alpha$-MICRO- GLOBULINA EM PACIENTES COM GLOMERULOPATIAS}

\section{Elen Almeida Romão}

Orientador: Prof. Dr. Márcio Dantas

Tese de Doutorado apresentada em 29/08/2008
Em condições normais a proteína $\alpha 1$-microglobulina $(\alpha 1-\mu \mathrm{g})$ é filtrada pelo glomérulo e totalmente reabsorvida pelo túbulo proximal. Lesão túbulo-intersticial, que pode estar 
presente em pacientes com doenças glomerulares, compromete a reabsorção da $\alpha 1-\mu \mathrm{g}$, levando a aumento da sua excreção urinária. Este estudo tem como objetivos avaliar se alguns distúrbios funcionais, inflamatórios e morfológicos associados com a lesão túbulo-intersticial interferem com a excreção urinária da $\alpha 1-\mu \mathrm{g}$ em pacientes com glomerulopatias.

Métodos: Foram avaliados 38 pacientes (33,6 \pm 11,3 anos) portadores de glomerulopatias primárias e secundárias diagnosticadas por biópsia renal. A dosagem urinária da $\alpha 1-\mu \mathrm{g}$ foi feita por nefelometria e expressada pela sua excreção fracional (FE $\alpha 1-\mu \mathrm{g})$, que se correlacionou positivamente com o índice $\alpha 1-\mu \mathrm{g}$ urinária/creatinina urinária $(\mathrm{r}=0,90 ; \mathrm{p}<0,0001)$. Além da proteinúria de 24 horas foi avaliada também a excreção urinária de monocyte chemoattractant protein-1/creatinina urinária ( $\left.\mathrm{U}_{\mathrm{MCP}-1}\right)$. Nas amostras das biópsias renais foram medidas a área intersticial cortical relativa (AICR), a área de fibrose intersticial cortical relativa (FIC) e o número de macrófagos f (células CD68 positivas) $/ 1000 \mu \mathrm{m}^{2}$ de área de tufo glomerular e de área túbulo-intersticial cortical. Os resultados foram expressos como mediana e variação. O teste não paramétrico de Spearman foi usado para os testes de correlação.
Resultados: A FE $\alpha 1-\mu \mathrm{g}$ foi de 0,165\% (0,008\% a $14,790 \%$ ) nos pacientes com glomerulopatias e de 0,065 $(0,010$ a 0,150$)$ no grupo controle ( $\mathrm{p}<0,05$; Mann-Whitney $\mathrm{U}$-Test). A FE $\alpha 1-\mu \mathrm{g}$ se correlacionou negativamente com o clearance de creatinina $(\mathrm{r}=-0,74 ; \mathrm{p}<0,001)$ e positivamente com a $\mathrm{U}_{\mathrm{MCP}-1}(\mathrm{r}=0,59 ; \mathrm{p}<0,0001)$, com o n ${ }^{\mathrm{o}}$ de macrófagos/glomérulo $(\mathrm{r}=0,43 ; \mathrm{P}<0,05)$, com o $\mathrm{n}^{\circ}$ de macrófagos/ área túbulo- intersticial $(\mathrm{r}=0,56 ; \mathrm{P}<0,005)$, e com a $\operatorname{AICR}(r=0,65 ; p<0,0001)$. Entretanto, a FE $\alpha 1-\mu g$ não se correlacionou nem com a proteinúria $(\mathrm{r}=0,15 ; \mathrm{P}=0,51)$ e nem com a área de FIC ( $\mathrm{r}=0,004 ; \mathrm{P}=0,98)$.

Conclusões: Em conclusão, os resultados do presente estudo dão suporte à hipótese de que a presença renal da quimiocina monocyte chemoattractant protein-1, a expansão intersticial cortical e a infiltração renal de macrófagos têm participação na fisiopatologia do aumento da excreção urinária da $\alpha 1$-microglobulina em pacientes com glomerulopatias. Entretanto, apesar de esperado, a proteinúria e a fibrose intersticial cortical não se associaram com este efeito, o que implica em investigações com outras abordagens para se confirmar o envolvimento destes mecanismos aqui estudados.

\section{RELAÇÃO ENTRE QUALIDADE DE VIDA E CONSTIPAÇÃO INTESTINAL CRÔNICA EM PA- CIENTES ATENDIDOS EM UM AMBULATÓRIO DE GERIATRIA DE UM HOSPITAL TERCIÁRIO}

\section{Patrícia Teixeira Meireles Villela \\ Orientador: Prof. Dr. Ricardo Brandt de Oliveira \\ Dissertação de Mestrado apresentada em 29/08/2008}

O estudo, de caráter descritivo transversal, teve como objetivos verificar a prevalência de constipação intestinal crônica entre os pacientes do ambulatório de geriatria geral do Hospital das Clínicas de Ribeirão Preto e a influência da constipação intestinal sobre a qualidade de vida desses pacientes.

Foram entrevistados 620 pacientes, de ambos os gêneros, com idade igual ou superior a 60 anos. Os dados foram coletados entre setembro de 2006 a maio de 2007 . As entrevistas foram realizadas pela pesquisadora, com questionário próprio para: identificação da presença, ou não, de constipação intestinal conforme os critérios Roma II, e para a obtenção das seguintes variáveis: gênero, idade, uso de laxante e duração de constipação.

Um instrumento medir qualidade de vida relacionada a saúde (SF-36) foi aplicado nos últimos 120 pacientes entrevistados, apresentassem ou não constipação intestinal, o SF-36 se divide em oito domínios: Capacidade Funcional, Aspecto Físico, Dor, Estado Geral de Saúde, Vitalidade, Aspecto Social, Aspecto Emocional, Saúde Mental.
Foram excluídos pacientes com: déficit cognitivo grave, conforme avaliação médica, deficiência física, pacientes acamados, pacientes que, por algum motivo, após aceitarem participar da pesquisa, apresentaram sinais de desconforto físico, ansiedade intensa ou outra reação emocional no início ou durante a aplicação do questionário.

Resultados e Conclusão: Dos 620 pacientes entrevistados, $306(49,3 \%)$ apresentavam constipação intestinal crônica, cuja prevalência foi significativamente maior ( $\mathrm{p}=0,004)$ entre as mulheres (203 das 428, 47,4 \%) do que entre os homens (54 dos 192 homens, 28,1\%). O estudo mostrou também a associação estatisticamente significativa entre gênero feminino e uso de laxante $(\mathrm{p}<0,001)$. O gênero masculino tem risco $40,4 \%$ menor do que o gênero feminino de desenvolver constipação intestinal crônica $(\mathrm{p}=0,003)$ e o risco de ter constipação aumenta $2,3 \%$ a cada ano em ambos os gêneros ( $p=0,042)$.

A qualidade de vida dos pacientes constipados foi significativamente menor do que a qualidade de vida dos pacientes não constipados, conforme todos os domínios do instrumento (SF-36). A menor média dos escores dos domínios foi a vitalidade.

O estudo obteve resultados satisfatórios de consistência Interna segundo Alfa de Crombach acima de 0,8 em todos os domínios do instrumento. 


\section{EFEITOS CLÍNICOS, FUNCIONAIS E INFLAMATÓRIOS DE BUDESONIDA 800 MCG AO DIA E BUDESONIDA 400 MCG ASSOCIADA A FORMOTEROL 24 MCG AO DIA NO TRATAMEN- TO DA ASMA}

\section{Marcelo Bezerra de Menezes}

Orientador: Prof. Dr. Elcio dos Santos Oliveira Vianna

Tese de Doutorado apresentada em 01/09/2008

Corticosteróides inalatórios e $\beta$-agonistas de ação prolongada são medicações de controle usadas comumente no tratamento da asma persistente. Para pacientes em uso somente de corticosteróide inalatório pode-se aumentar a dose do mesmo ou associar um $\beta$-agonista de ação prolongada para incrementar o tratamento. Enquanto a segunda opção parece gerar melhor controle clínico, ainda não se tem certeza quanto a sua atuação na inflamação de vias aéreas. O objetivo deste estudo foi comparar parâmetros clínicos, funcionais e inflamatórios de asmáticos antes e depois de intervenções terapêuticas específicas: aumento da dose de corticosteróide ou adição de um $\beta$-agonista de ação prolongada ao tratamento previamente usado com budesonida (corticosteróide). Para tanto, empreendemos estudo randomizado, duplo-cego em que asmáticos passaram por um período pré-randomização usando budesonida $400 \mathrm{mcg}$ ao dia por 6 semanas, após as quais foram randomizados para receber $800 \mathrm{mcg}$ ao dia de budesonida (grupo BUD) ou $400 \mathrm{mcg}$ de budesonida mais $24 \mathrm{mcg}$ de formoterol (grupo FORMO) por mais 9 semanas (período pós-randomização). Ao final de cada período eram submetidos a avaliação clínica, avaliação de medidas de pico de fluxo expiratório (PFE), espirometria, broncoprovocação com solução salina hipertônica (SSH) e escarro induzido (a partir do qual eram realizadas lâminas para contagem diferencial de célu- las, cultura de células e dosagens no escarro e no meio de cultura de interleucina-4 (IL-4), tumor necrosis factor- $\alpha$ (TNF- $\alpha$ ) e eotaxina-2). Vinte pacientes com asma persistente completaram o estudo (10 em cada grupo). A taxa de exacerbações (pacientes que sofreram exacerbação / pacientes randomizados) foi maior no grupo BUD do que no grupo $\operatorname{FORMO}(8 / 19$ e $1 / 13$, respectivamente; $p<0,05)$. Os valores de PFE matutino e noturno em porcentagem do previsto aumentaram no período pós-randomização somente no grupo FORMO (média \pm desvio-padrão de PFE matutino pré $\mathrm{x}$ pós: $93,4 \pm 22 \%$ x $105,5 \pm 24,2 \%$; $\mathrm{p}<0,01$. PFE noturno pré x pós: $91,8 \pm 21,7 \%$ x 106,9 $\pm 23,6 \% ; \mathrm{p}<0,01$ ). As contagens de neutrófilos no escarro, em porcentagem de leucócitos, aumentaram em ambos os grupos no período pós-randomização (grupo BUD pré x pós: $29,0 \pm 14,1 \%$ x 39,2 $\pm 11,0 \% ; \mathrm{p}<0,05$. Grupo FORMO pré x pós: $23,0 \pm$ $12,6 \%$ x 39,3 $\pm 18,1 \% ; \mathrm{p}<0,05)$. A viabilidade de leucócitos (porcentagem de células viáveis) após cultura aumentou somente no grupo FORMO (viabilidade pré x pós: 87,4 \pm $7,2 \%$ x 93,3 $\pm 3,9 \%$ ). Nenhum outro parâmetro se alterou significativamente em qualquer dos grupos ao se comparar pré- e pós-randomização. Este estudo mostrou que a associação de corticosteróide com $\beta$-agonista de ação prolongada aumentou valores de PFE e diminuiu taxa de exacerbações, apesar de possível ação pró-inflamatória em culturas de leucócitos do escarro, conforme inferido a partir do aumento de viabilidade de um subgrupo dessas células mediante o regime. Ambos esquemas terapêuticos testados causaram aumento de neutrófilos no escarro.

\section{AVALIAÇÃO DA COMPOSIÇÃO CORPORAL, FORÇA MUSCULAR, DESEMPENHO FUNCIO- NAL DE MEMBROS INFERIORES E SUA CORRELAÇÃO COM A ATIVIDADE FÍSICA RELATA- DA DE IDOSOS INDEPENDENTES}

\section{Paulo Fernandes Formighieri}

Orientador: Prof. Dr. Eduardo Ferrioli

Dissertação de Mestrado apresentada em 01/09/2008

O aumento da expectativa de vida tem levado à necessidade de sérias reflexões sobre a qualidade do envelhecimento a ser oferecido à população, pois a mudança do perfil epidemiológico que acompanha o novo perfil demográfico traz consigo um grande contingente de indivíduos sob risco do desenvolvimento de restrições funcionais, dependência e perda de autonomia. O entendimento do pro- cesso de envelhecimento músculo-esquelético, intimamente relacionado ao desempenho físico e funcional ainda está longe de ser completo, o que é corroborado por achados inconstantes na literatura. O presente estudo objetivou caracterizar e correlacionar a composição corporal de população idosa independente com marcadores de força muscular e desempenho funcional, e estes entre si. Ainda buscou entender a influência dos hábitos de atividade física sobre estas variáveis. Foram estudados 101 voluntários entre 60 a 75 anos de idade, distribuídos entre os gêneros, sem comprometimentos físicos e psíquicos limitantes. Os 
voluntários além da coleta de exames séricos basais e entrevista clínica por médico, foram submetidos a avaliação de composição corporal por DXA, avaliação do desempenho funcional de membros inferiores por meio de Teste de Caminhada de 6 minutos, dinamometria de preensão manual e aplicação do Questionário Internacional de Atividade Física (IPAQ). Foram realizados, além da análise descritiva, análises de correlação bivariada (ANOVA quando indicado), seguidos de regressão linear para corrigir a influência da altura e IMC, utilizando-se nível de significância menor ou igual a 0,05 . Os resultados foram interpretados à luz de relatos da literatura científica da área, procurando-se relacionar os achados com hábitos culturais específicos da população. Não foram identificadas correlações lineares entre força muscular e desempenho funcional, ou da atividade física relatada com as demais variáveis. A massa muscular e massa gorda correlacionaram-se diretamente com força e T6min entre homens, já em mulheres a correlação foram verificadas apenas após correção de altura e IMC. Pode-se concluir que a entre os componentes da composição corporal a massa gorda vem se tornando um importante foco da atenção no entendimento das relações entre composição, força e desempenho físico. Conclui-se ainda que há necessidade preemente de novos estudos para caracterizar a população de idosos brasileiros no tocante a estes tópicos.

\section{DETECÇÃO PRECOCE DO COMPROMETIMENTO DE NERVO PERIFÉRICO EM COMUNICAN- TES INTRADOMICILIARES DE PACIENTECS COM HANSENÍASE}

\section{Renata Bazan Furini \\ Orientadora: Profa. Dra. Norma Tiraboschi Foss \\ Dissertação de Mestrado apresentada em 19/09/2008}

Hanseníase constitui um relevante problema de saúde pública no Brasil, com elevada detecção de casos novos nos últimos anos, apresentando 39.125 pacientes em tratamento no ano de 2007, sendo $8 \%$ deles com incapacidade física já instalada (3.239 pessoas em apenas um ano). Esses dados representam a magnitude e complexidade do problema. Alia-se a esses números a alta infectividade da doença, tomando pessoas que convivem com os doentes (o comunicante intradomiciliar) alvo para o desenvolvimento da infecção. Sabe-se que o Mycobacterium leprae, agente etiológico, tem tropismo preferencial por nervo periférico, no qual a lesão precede a manifestação cutânea e, também, que esse bacilo possui a fração antigênica específica PGL, capaz de induzir a produção do anticorpo anti PGL1 (APGL1), quantificado no soro por ELISA (enzyme linked immunosorbent assay). Assim, para a detecção precoce da doença, propõe-se a vigilância desses comunicantes com avaliação dos níveis de APGL 1 e do comprometimento neurológico na tentativa de evitar a instalação de incapacidade física. Para verificar a importância dos níveis de APGL1 no desenvolvimento da doença, comunicantes intradomiciliares APGL1 acima do “cut off' (APGL1 $\geq 1$ ) foram pareados por sexo, idade e profissão com APGL1 abaixo do "cut off' (APGL $1<1$ ). Constatou-se que os comunicantes com APGL $\geq 1$ são mais suscetíveis de desenvolver a hanseníase. Foram selecionadas, ao acaso, 120 famílias de pacientes com hanseníase do Hospital das Clínicas da Faculdade de Medicina de Ribeirão Preto-USP (HCFMRP-USP) e 24 pares de comunicantes intradomicilares que foram submeti- dos ao ultra-som (US) e à eletroneuromiografia (ENMG) para avaliação morfológica funcional de nervos periféricos. Trezentos e vinte e um comunicantes intradomiciliares foram avaliados por meio do exame clínico (dermato-neurológico) para se obter os níveis de APGL1. Os resultados mostram, inicialmente, que em $3,4 \%$ (11 comunicantes intradomiciliares) obteve-se o diagnóstico de hanseníase, confirmado com exame histopatológico, sendo cinco pacientes de hanseníase Indeterminada-HI e dois de hanseníase Virchowiana-HV, ilustrando a importância da busca ativa na detecção precoce $(\mathrm{HI})$ e, principalmente, na revelação da prevalência oculta (HV). Foi encontrado, ainda, que 15,9\% (51/321) dos comunicantes apresentavam APGL $\geq$, sendo mais freqüentes $(62,5 \%)$ entre os comunicantes de pacientes multibacilar (HV, HDV e HD). Observaram-se nos US alterações em nervos fíbula comum e ulnar, não relacionadas aos níveis de APGL'1 e a ENMG. Revelou-se, ainda, neuropatia sensitiva do nervo ulnar na maioria, sendo freqüente mais de um nervo acometido em um mesmo indivíduo, achado comum da moneurite múltipla da hanseníase. Um relevante número $(66,5 \%)$ de comunicantes com APGL $\geq 1$ apresentou alterações ENMG características da hanseníase. Dessa forma, pode-se concluir que no controle da hanseníase a avaliação de comunicantes é fundamental para a detecção precoce e a prevalência oculta, e que APGL1 pode ser uma ferramenta eficaz para auxiliar na detecção precoce. Além disso, a ENMG se mostrou um exame mais sensível que o US na detecção de alterações em nervos periféricos de comunicantes intradomiciliares, provavelmente porque a alteração funcional do componente sensitivo do nervo, forma inicial de comprometimento, precede o desenvolvimento de alterações da imagem morfológica, logo, pode ser sugerido que a ENMG é instrumento útil para a detecção precoce e bloqueio da transmissão da hanseníase. 


\section{AVALIAÇÃO DO EFEITO DA SUBSTITUIÇÃO DO CARVEDILOL PELO PROPRANOLOL EM PACIENTES PORTADORES DE INSUFICIÊNCIA CARDÍACA}

\section{Fabiana Marques}

Orientador: Prof. Dr. Marcus Vinícius Simões

Dissertação de Mestrado apresentada em 23/09/2008

Introdução: bisoprolol, metoprolol e carvedilol foram avaliados em grandes ensaios clínicos e apresentaram impacto positivo na insuficiência cardíaca. É plausível que o efeito benéfico seja extensível a outros beta-bloqueadores. Propranolol, bloqueador adrenérgico $\beta 1 \beta 2$, sem ligação aos receptores foi pouco avaliado na insuficiência cardíaca.

Objetivos: avaliar o impacto da substituição do carvedilol por propranolol sobre o remodelamento miocárdico, qualidade de vida, capacidade funcional, controle autonômico, densidade de arritmias e controle pressórico.

Casuística e métodos: 29 pacientes com insuficiência cardíaca compensada em uso de terapêutica otimizada incluindo uso de carvedilol em dose máxima tolerada por período mínimo de seis meses foram divididos em dois grupos: um grupo, onde o carvedilol foi substituído por propranolol (15 pacientes, 3 femininos, $54 \pm 8,0$ anos) e outro onde a terapêutica com carvedilol foi mantida (14 pacientes, 8 femininos, 51,8 \pm 9,2 anos). Os pacientes foram submetidos à avaliação clínica e laboratorial incluindo ventriculografia nuclear, ecocardiografia, Holter, avaliação da qualidade de vida, teste de caminhada e MAPA.

Resultados: as características laboratoriais e demográficas foram similares nos dois grupos; com exceção da pressão arterial diastólica média em 24 horas. Apenas um paciente apresentou intolerância ao propranolol sendo necessário retorno para carvedilol. Foi necessário aumento transitório da dose de diuréticos em 3 pacientes após substituição do beta-bloqueador. Ajuste fino e individualizado da dose do propranolol garantiu mesmo grau de beta-bloqueio que foi confirmado pelos dados da frequiência cardíaca e da reserva cronotrópica. A avaliação da fração de ejeção do ventrículo esquerdo pela ventriculografia nuclear mostrou aumento significativo $(\mathrm{p}=0,048)$ no grupo de introdução do propranolol. A distância percorrida no teste de caminhada, o diâmetro diastólico do ventrículo esquerdo, o escore de Minnesota, o SDNN, o número de extrasístoles ventriculares por hora e número de episódios de TVNS não sofreram modificações significativas após troca do beta-bloqueador.

Conclusão: a substituição do carvedilol por propranolol não se associou à deterioração das variáveis estudadas em pacientes com insuficiência cardíaca sistólica. A troca de carvedilol por propranolol pode estar associada a aumento da fração de ejeção por mecanismos ainda não esclarecidos.

\section{FIBROSE PULMONAR EXPERIMENTAL : POTENCIAL TERAPÊUTICO DAS CÉLULAS-TRONCO DA MEDULA ÓSSEA}

\section{Fabíola Paula Galhardo Rizzatti}

Orientador: Prof. Dr. José Antônio Baddini Martinez

Tese de Doutorado apresentada em 23/09/2008

A fibrose pulmonar idiopática é uma doença pulmonar fibrosante incurável, que causa significativa morbidade e diminuição da expectativa de vida, para a qual novas opções terapêuticas são claramente necessárias. Estudos recentes mostraram que células-tronco da medula óssea (CTMO) podem migrar para locais de lesão pulmonar e se diferenciar em células somáticas, auxiliando na regeneração do tecido lesado. No entanto, trata-se de um conceito relativamente recente, existindo poucos estudos sobre o potencial papel das CTMO nas lesões fibróticas pulmonares. Além disso, quando objetivo é a regeneração do tecido pulmonar lesado, ainda é preciso que se estabeleça a melhor via de administração das CTMO. Neste estudo, investigamos os efeitos da administração endovenosa (EV) ou intratraqueal (IT) de células-tronco provenientes da medu- la óssea não fracionada num modelo experimental de fibrose pulmonar em camundongos C57BI/6. Para indução de lesão pulmonar, a droga citotóxica bleomicina $(0,15 \mathrm{U} / 30 \mathrm{~g})$ foi administrada por via intratraqueal. Cinco dias após a exposição à bleomicina, $1 \times 10^{7}$ células da medula óssea de camundongos $\mathrm{C} 57 \mathrm{~B} 1 / 6$ isogênicos foram administradas pelas vias $\mathrm{EV}$ ou IT. Oito semanas após a exposição à bleomicina, realizou-se o sacrifício dos camundongos, obtendo-se tecido pulmonar para posterior análise. Para confirmar que as CTMO efetivamente se implantaram no tecido pulmonar lesado, realizamos experimentos num subgrupo de animais em que as CTMO transplantadas foram provenientes de camundongos geneticamente modificados para expressar a proteína fluorescente eGFP de modo constitutivo. As células eGFP positivas implantadas pulmão dos animais receptores foram identificadas por microscopia de fluorescência do tecido pulmonar. Com o objetivo de I elucidar os efeitos da administração EV das CTMO na lesão fibrótica pulmonar induzi da pela bleomicina, estudamos 118 camundon- 
gos distribuídos em 4 subgrupos: BleoCT_ev, animais que receberam bleomicina IT e CTMO EV; BleoSal_ev, animais que receberam i bleomicina IT e salina EV; SaICT_ev, animais que receberam salina IT e CTMO EV; e f SaISal_ev, animais que receberam salina IT e salina EV. Para a investigação dos efeitos da administração IT das CTMO, estudamos 81 animais distribuídos em 4 subgrupos: BleoCT_it, animais que receberam bleomicina e CTMO IT; BleoSal_it, animais que receberam bleomicina e salina IT; SalCT_it, animais que receberam salina e CTMO IT; e SalSal_it, animais que receberam salina e salina IT. Nossos resultados demonstraram que independentemente da via de administração (EV ou IT), as células derivadas da medula óssea não fracionada de camundongos transgênicos para a expressão da eGFP implantaram- se no tecido pulmonar lesado e passaram a expressar marcadores epitelais de superfície, como citoqueratinas e proteína A do surfactante. A administração IT de bleomicina promoveu significativa fibrose pulmonar nos animais que receberam a droga em comparação aos animais controles (salina IT). O grau de fibrose foi comparável em ambos os grupos de estudo (EV e IT), conforme evidenciado pela análise histológica e pela dosagem de hidroxiprolina tecidual pulmonar. No grupo de estudo EV, a adminstração das CTMO não se associou com redução na deposição de colágeno, conforme avaliado pela morfometria do tecido pulmonar corado pelo picrosírius e pela dosagem tecidual pulmonar de hidroxiprolina. Também não observamos redução na mortalidade no subgrupo que recebeu bleomicina e CTMO (BleoCT_ev), em relação ao subgrupo que recebeu a bleomicina isoladamente (BleoSal_ev) $(29,41 \%$ vs 31,7\%). No entanto, houve redução significativa do percentual médio da área ocupada pelo interstício septal no subgrupo BleoCT_ev em relação ao subgrupo BleoSal_ev $(59,1 \%$ vs 67,5\%,p < 0,001). Resultados semelhantes foram obtidos nos subgrupos em que as CTMO foram administradas por via IT; todavia, neste caso, observou-se uma redução significativa da mortalidade no subgrupo BleoCT_it em relação ao subgrupo controle BleoSal_it $(14,81 \%$ vs 53,84\%, p=0,0017). Além disso, a instilação IT de células-tronco derivadas da medula óssea não fracionada no subgrupo que recebeu a bleomicina (subgrupo BleoCT_it) também resultou em diminuição do percentual médio da área ocupada pelo interstício septal; no entanto, essa diferença não atingiu significância estatística na comparação com o subgrupo controle (BleoSal_it) $(72,63 \%$ vs $67,14 \%, \mathrm{P}>0,05)$. Em agregado, nossos resultados evidenciaram que a administração EV ou IT de CTMO, cinco dias após a indução de lesão pulmonar por bleomicina, resultou em migração e implantação dessas células no tecido pulmonar lesado, onde assumiram um fenótipo epitelial. Nossos resultados sugerem que os efeitos terapêuticos da administração de CTMO deveram-se à redução da área ocupada pelo septo intersticial pulmonar, possivelmente por redução de seu componente inflamatório, uma vez que não alterou significantemente a deposição de colágeno tecidual.

\section{MEDIDA DA PRESSÃO ARTERIAL, AVALIAÇÕES LABORATORIAIS E ANTROPOMÉTRICAS NO OBESO GRAU III NORMOTENSO, PRÉ E PÓS CIRURGIA BARIÁTRICA}

\section{Adélia Paula de Castro}

Orientador: Prof. Dr. José Ernesto dos Santos

Tese de Doutorado apresentada em 29/09/2008

As consequiências da cirurgia bariátrica sobre o organismo são muito investigadas atualmente. A pesquisa aborda a medida casual da pressão arterial (PA) no braço e a monitorização ambulatorial da pressão arterial (MAPA) e outros fatores de risco de doença aterosclerótica em obesos grau III submetidos à cirurgia bariátrica técnica de FobiCapela. Conduzido no Ambulatório de Cirurgia Bariátrica do Hospital das Clínicas da Faculdade de Medicina de Ribeirão Preto -Universidade de São Paulo (HCFMRP-USP). Avaliados 11 obesos grau III (10 mulheres e 1 homem, 73\% com menos de 37 anos) no pré-operatório (exame I) e aos 2 e 6 meses de pós-operatório (exames II e III respectivamente). Determinaram-se também os níveis de colesterol total (CT), liproteína de baixa densidade-colesterol (LDL-c), liproteína de alta densidade-colesterol HDL-c, triglicérides
(TG), glicemia (GL) e proteína C reativa (PCR) ultra-sensível. Aplicado o teste estatístico de Friedman. Não houve diferenças pela MAPA, nas médias de PA, tanto para pressão arterial sistólica (PAS) quanto para a pressão arterial diastólica (PAD). Na medida de 24 horas a PAS foi de $110,6 \mathrm{mmHg}$ (exame I) $\pm 7,2$ e no exame II de 106,1 $\mathrm{mmHg} \pm$ $13,5,(\mathrm{p}=0,31)$; a medida PAD foi de $64,5 \mathrm{mmHg} \pm 5,8$ (exame I), e no exame III 64,2mmHg $\pm 10,8,(p=0,93)$. Na vigília também não houve diferenças na PAS $112,3 \mathrm{mmHg} \pm 8,1$ (exame I), e no exame III 106,6 $\mathrm{mmHg} \pm 13,7$, (p=0,31) como na PAD 66,4mmHg $\pm 6,6$ (exame I), e no exame III 65,0mmHg $\pm 11,5$, (p 0,91). Durante o sono, também não foram observados diferenças o mesmo foi observado na PAS $106,3 \mathrm{mmHg} \pm 7,2$ (exame I) e no exame III 103,7 $\mathrm{mmHg} \pm$ $12,9,(\mathrm{p} 0,76)$ e para PAD 59,3mmHg $\pm 6,6$ (exame I) e no exame III $62,1 \mathrm{mmHg} \pm 10$ ( $\mathrm{p}=0,41)$. Na medida casual observamos diferenças significativas: PAS no braço esquerdo $111,4 \mathrm{mmHg} \pm 7,8$ (exame I) e no exame III 96,5mmHg $\pm 10,3$, $(\mathrm{p}<0,01)$, e no braço direito, $113,4 \mathrm{mmHg} \pm 6,3$ (exame I) e 
no exame $\pm 98,3 \mathrm{mmHg} \pm 8,3,(\mathrm{p}=0,01)$. A medida PAD no braço esquerdo foi $71,5 \mathrm{mmHg} \pm 8,1$ (exame I) e no exame III $65,4 \mathrm{mmHg} \pm 8,1$ ( p 0,03) e no direito 75,3mmHg $\pm 9,8$ (exame I) e no exame III $67,6 \mathrm{mmHg} \pm 10,6, \mathrm{p}=0,06$. Houve diferença significativa no índice de massa corporal (IMC) do exame I para o III de $12,0 \mathrm{Kg} / \mathrm{m}^{2}(\mathrm{p}<0,01)$, no peso 30,6 kg ( $\left.\mathrm{p}<0,01\right)$, e na circunferência abdominal (CA) $21,9 \mathrm{~cm}(\mathrm{p}<0,01)$. Similar ao CT (redução de 29,09mg/dl -p < 0,01) na trigliceridemia (redução 47,18mg/dl, p < 0,01) e no HDL-c (aumento de 0,09mg/dl- p=0,08), no LDL-c (redução de 19,81 mg/dl, $\mathrm{p}=0,03$ ) na glicemia (redução de $7,09 \mathrm{mg} / \mathrm{dl}, \mathrm{p}=0,49$ ) e na PCR (redução de 0,88mg/dl -p < 0,01). Este estudo sugere manutenção da normalidade da pressão arterial dos obesos grau III normotensos no pré operatório, e após cirurgia bariátrica (exame II e III) tanto pela MAPA quanto pela medida casual. A perda de peso associada à cirurgia bariátrica promove redução da CA, IMC e melhora do perfil lipídico, glicemia e PCR.

\section{FARMACOLOGIA}

\section{EFEITOS DA LERCANIDIPINA SOBRE ALTERAÇÕES CARDIOVASCULARES PRESENTES EM MODELOS DE HIPERTENSÃO ARTERIAL E DIABETES MELLITUS EM RATOS}

\section{Márcio Luís Lombardi Martinez \\ Orientador: Prof. Dr. José Eduardo Tanus dos Santos \\ Tese de Doutorado apresentada em 05/08/2008}

Hipertensão e Diabetes são dois dos principais fatores de risco para o desenvolvimento de aterosclerose e doença da artéria coronária. Tais enfermidades aumentam o risco cardiovascular a índices muito elevados, e são acompanhadas por uma alteração fisiopatológica comum, que é o remodelamento vascular acelerado, caracterizado pelo desarranjo na regulação da atividade das metaloproteinases (MMPs) associado ao aumento do "stress" oxidativo. Um dos modelos mais semelhantes ao quadro de hipertensão renovascular em humanos é o modelo de hipertensão renovascular unilateral (2R-1C), que é produzido pelo clampeamento de uma das artérias renais, e manutenção do rim contra lateral intacto. Por outro lado, a Aloxana tem sido extensivamente utilizada como modelo de indução química dos tipos de diabetes não-insulino dependentes. Este remodelamento vascular acelerado presente na hipertensão bem como na diabetes está associado a ativação de um grupo de endopeptidases zinco-dependentes denominadas metaloproteinases, que têm sido implicadas no remodelamento vascular subjacente à aterosclerose. MMPs têm sido reconhecidas como um grupo de enzimas envolvidas na degradação de componentes da matriz extracelular em processo fisiológicos, bem como patológicos, e uma aumentada expressão e atividade de MMP pode resultar num remodelamento cardiovascular exacerbado e aterosclerose da artéria coronária. Lercanidipina é um bloqueador de canal de cálcio (CCB) da classe das diidropiridinas usado para tratamento da hipertensão. Além de reduzir a pressão arterial, há evidências de que a lercanidipina tenha ações pleiotrópicas que possam significativamente contribuir para os benefícios que ela produz na terapia da hipertensão. É possível que a lercanidipina e outros CCB com efeitos antioxidantes reduzam a atividade/ expressão das MMPs na hipertensão e diabetes. Baseado nestas informações, o os objetivos do nosso trabalho foram primeiramente, verificar possíveis aumentos de "stress" oxidativo e de MMP-2 (atividade e expressão gênica) nos vasos de ratos nos modelos de hipertensão arterial renovascular e diabetes mellitus citados. Objetivamos ainda estudar os efeitos do tratamento com lercanidipina sobre as alterações mencionadas anteriormente. E como terceiro objetivo, buscamos estudar os efeitos do tratamento com lercanidipina sobre a disfunção vascular presentes nos dois modelos experimentais de hipertensão arterial e de diabetes mellitus. Os resultados deste estudo mostraram que o tratamento com lercanidipina reduziu a pressão arterial sistólica nos ratos hipertensos e diabéticos. Além disso os animais tratados com tratamento com lercanidipina apresentaram uma redução significativa nos níveis plasmáticos de malondialdeído e da atividade da MMP-2. Os animais diabéticos tratados com lercanidipina, apresentaram ainda um aumento da expressão de RNAm de TIMP-2. Em conclusão, nossos resultados sugerem que a lercanidipina produziu efeitos antihipertensivos e reverteu a disfunção endotelial associada com a hipertensão 2R-1C e diabetes mellitus induzida pela aloxana, provavelmente através de mecanismos envolvendo efeitos antioxidantes, o que levaria a uma menor ativação da MMP-2. Nossos achados sugerem que as drogas antihipertensivas com atividade antioxidante podem inibir a ativação da MMP-2 e colaborar na prevenção a aterosclerose. 


\section{PARTICIPAÇÃO DOS RECEPTORES DE GLUTAMATO TIPO NMDA PRÉ-SINÁPTICOS NA SEN- SIBILIZAÇÃO DOS NEURÔNIOS AFERENTES PRIMÁRIOS}

\section{Luiz Fernando Ferrari}

Orientador: Prof. Dr. Sérgio Henrique Ferreira

Tese de Doutorado apresentada em 11/08/2008

A sensibilização retrógrada dos neurônios aferentes primários, primeiramente descrita na última década do século passado, associava receptores glutamatérgicos N-metilD- aspartato (NMDARs) pré-sinápticos à diminuição do limiar de ativação dos nociceptores. Posterionnente, também foi sugerido que esse processo retrógrado estaria relacionado a um mecanismo intracelular de comunicação e integração entre os terminais opostos do neurônio aferente primário (NAP). Utilizando o teste comportamental de von Frey eletrônico e microscopia confocal, o presente trabalho investigou os mecanismos pelos quais os NMDARs présinápticos induzem a sensibilização do NAP e como ocorre a comunicação entre diferentes regiões da célula neuronal. Primeiramente foi observado que os NMDARs presentes no gânglio da raiz dorsal (GRD) de ratos Wistar são fundamentais para o desenvolvimento e manutenção da hipemocicepção de origem inflamatória, a qual foi bloqueada pela administração intraganglionar (i.gl.) do antagonista seletivo para esse receptor, D-AP-5. Experimentos com o bloqueio temporário da expressão de subunidades de NMDARs (NRI, NR2a-d e NR3a-b) mostraram que NMDARs ganglionares compostos pelas subunidades NR1, NR2b, NR2d ou NR3a participam da hipemocicepção periférica. Mais ainda, observações por microscopia confocal em culturas de neurônios do GRD sugeriram que estes receptores provavelmente possuem subunidades NR3, que diminuem a susceptibilidade ao bloqueio por magnésio $\left(\mathrm{Mg}^{+2}\right)$ e a necessidade de despolarização prévia para funcionamento. Interessantemente, apenas NMDARs localizados nas células da glia ganglionares (células satélites) foram ativados nas culturas após adição de NMDA. Esses receptores também foram relacionados à ativação de oscilações de cálcio $\left(\mathrm{Ca}^{+2}\right)$ intraneuronais (conhecidas como CICR), um dos possíveis mecanismos responsáveis pela comunicação das diferentes regiões neuronais. A hipemocicepção induzida por injeção intratecal (i.t.) de NMDA foi bloqueada por antagonistas de CICR, confirmando nossa hipótese. Além disso, tanto o $\mathrm{Ca}^{+2}$ extracelular quanto intracelular, liberado pela ativação de receptores envolvidos com a CICR, após a ativação de NMDARs ganglionares, parecem ser importantes para a sensibilização do NAP como um todo. Em adição à CICR, consideramos também a participação de proteínas quinases (PKCe e PKA) neste processo de comunicação intraneuronal, já que foram observadas alterações na expressão destas proteínas no GRD após estimulação inflamatória na pata de animais. A inibição, pelo D-AP-5 i.gl., da hipemocicepção induzida por agonistas de PKC8 ou de PKA, administrados na pata, somada à inibição da hipemocicepção induzida pelo NMDA i.t. por inibidores dessas proteínas quinases administrados no GRD, sugere que tais mensageiros intracelulares podem ser ativados no GRD via NMDARs ganglionares e que estas proteínas podem induzir liberação de GLU e ativar estes receptores. Mais ainda, indica fortemente que estas proteínas quinases, paralelamente à CICR, estão envolvidas no mecanismo de comunicação intraneuronal estudado. Considerando os resultados em conjunto, concluímos que os NMDARs presentes nas células satélites do GRD participam ativamente da hipemocicepção inflamatória do NAP, estimulando mecanismos que levam à integraçãodas diferentes regiões das células neuronais. Esses mecanismos seriam dependentes da entrada de $\mathrm{Ca}^{+2}$ via estes receptores e da liberação de $\mathrm{Ca}^{+2}$ do retículo endoplasmático, ativando a CICR e, possivelmente, segundos-mensageiros intracelulares.

\section{EFEITO PROTETOR MIOCÁRDICO DA INIBIÇÃO DE METALOPROTEINASES DE MATRIZ EXTRACELULAR DURANTE EMBOLIA PULMONAR AGUDA EM CÃES}

\section{Evandro Manoel Neto-Neves}

Orientador: Prof. Dr. José Eduardo Tanus dos Santos Dissertação de Mestrado apresentada em 04/09/2008

Embolia pulmonar aguda (EPA) é uma importante causa de morbidade e mortalidade. Recentes estudos têm mostrado a importância da vasoconstrição pulmonar que ocorre após a EPA. Um grupo de enzimas zinco dependentes designadas metaloproteinases de matriz extracelular estão envolvidas na degradação de componentes da matrix extracelular e possivelmente participam da lesão miocárdica.
Atualmente tem sido mostrado aumento na liberação de Tnlc em pacientes com disfunção ventricular em decorrência de EPA. Sendo assim, o objetivo deste trabalho foi avaliar se a inibição das MMPs poderia resultar em efeitos benéficos na disfunção ventricular induzida pela EPA. Os cães do grupo Sham $(n=5)$ receberam apenas salina, EPA foi induzida por infusão de coágulos autólogos injetados dentro do ventrículo direito no grupo Emb. $(\mathrm{n}=1 \mathrm{O})$; os cães do grupo Doxy $(n=5)$ receberam apenas infusão de doxiciclina $(10 \mathrm{mg} / \mathrm{kg}$ ) por via intravenosa em 5 minutos; e os cães do grupo Doxy+Emb $(n=10)$ receberam a mesma dose de doxiciclina antes da indução da EPA. Foram reali- 
zadas medidas da atividade das MMPs em amostras de plasma e de ventrículo direito. A migração de neutrófilos para o ventrículo direito foi avaliado pelo ensaio de atividade da mieloperoxidase (MPO) e a liberação de Tnlc por imunoensaio enzimático. Nenhuma diferença significativa foi encontrada nos grupos Sham e Doxy. A indução da EPA aumentou a pressão média da artéria pulmonar (de $12 \pm 1$ para $31 \pm 2 \mathrm{mmHg}$ ), o índice de resistência vascular pulmonar (de $142 \pm 23$ para $828 \pm 120$ dyn.s.cm), a atividade das MMPs (avaliada por gel de zimografia, espectrofluorimetria e zimografla in Situ), a migração de neutrófilos e a liberação de troponina I no grupo Emb $(\mathrm{P}<0,05)$. Entretanto, o prétratamento com doxiciclina preservou o índice cardíaco, reduziu a pressão média da artéria pulmonar para $26 \pm 1 \mathrm{mmHg}$, o índice de resistência vascular pulmonar para $514 \pm 41$ dyn.s.cm, a atividade das MMPs, a migração de neutrófilos, bem como a liberação de troponina I (de 61\% para 41\%) 120 minutos após a indução da EPA no grupo Doxy+Emb (P $<0,05)$. Esses resultados sugerem que a inibição das MMPs protegem o miocárdio contra aumentos na liberação de troponina I induzido pela EPA, possivelmente resultando em efeitos hemodinâmicos benéficos.

\section{PARTICIPAÇÃO DO NÚCLEO PRETECTALANTERIOR NO SISTEMA NOCICEPTIVO INIBITÓRIO DESCENDENTE EM RATOS SUBMETIDOS A ELETROACUPUNTURA COM DOIS 2HZ E 100HZ}

\section{Marcelo Lourenço Silva}

Orientador: Prof. Dr. Wiliam Alves do Prado

Dissertação de Mestrado apresentada em25/09/2008

O núcleo pretectal anterior (NPtA) é uma estrutura do mesencéfalo que participa dos mecanismos nociceptivos e antinoceptivos. O papel do NPtA no controle antinociceptivo é demonstrado pela estimulação elétrica que produz forte antinocicepção no modelo de dor fásica acompanhada pela ausência de comportamentos aversivos. Foi demonstrado que a administração de naloxana no NPtA bloqueia a inibição da latência induzida pela eletroacupuntura de baixa (LEA), mas não de alta (HEA) frequiência. Entretanto, o conhecimento preciso sobre os mecanismos neurais subjacentes à modulação da nocicepção pela EA ainda requer estudos futuros. Este estudo investigou o envolvimento do NPtA na antinocicepção induzida pela eletroacupuntura em modelo de dor aguda em ratos. Ratos machos Wistars $(160 \mathrm{~g})$ foram submetidos à lesão do funículo dorsolateral (FDL) e submetidos a 20 minutos de LEA ou HEA nos pontos Zusanli (E36) e Sanyinjiao (BP6) e posteriormente ao teste de retirada de cauda (R.C.) por 30 min. Em outro grupo foram implantadas cânulas bilateral- mente no NPtA ou na porção dorsal do NPtA (dNPtA) e submetidos à LEA e HEA e ao teste de R.C por $30 \mathrm{~min}$. A LEA produz aumento imediato da latência de R.C durante 30 minutos, significativamente maiores do que as do grupo controle. A HEA também produziu aumento imediato da latência de R.C. resultando curva semelhante ao da LEA, porém, decaiu acentuadamente 10 minutos após a estimulação. Com a lesão do FDL a LEA e a HEA produziram latências significativamente menores do que as do grupo controle. O bloqueio neural do NPtA com lidocaína impediu por completo o efeito antinociceptivo da LEA, no entanto na HEA o bloqueio atenuou, mas não impediu o aumento imediato das latências de R.C. e ainda reduziu também a duração. O bloqueio do dNPtA aboliu o efeito antinociceptivo da LEA, mas não impediu o efeito da HEA. Estes resultados nos levaram a concluir que: (1) a LEA e a HEA produz antinocicepção, com características diferentes em relação à intensidade e a duração do efeito; (2) a lesão do FDL abole os efeitos da LEA e da HEA; (3) o bloqueio neural do NPtA abole o efeito da LEA, e reduz a intensidade e a duração do efeito obtido pela HEA; (4) o bloqueio do dNPtA abole o efeito da LEA e não interfere na antinocicepção obtida pela HEA.

\section{FISIOLOGIA}

\section{BULBO OLFATÓRIO: PARTICIPAÇÃo NA MODULAÇÃO DA REAÇÃO DE ALARME E SUAS CO- NEXÕES INTRÍNSECAS E EXTRÍNSECAS NO PIAUÇU Leporinus macrocephalus}

\author{
Augusto Barbosa Junior \\ Orientadora: Profa. Dra. Anette Hoffmann \\ Dissertação de Mestrado 01/08/2008
}

O presente trabalho foi desenvolvido com o objetivo de estudar a participação do bulbo olfatório na modulação da reação de alarme e suas conexões intrínsecas e 
extrínsecas no piauçu Leporinus macrocephalus, porque estudos hodológicos aliados a dados funcionais podem fornecer subsídios adicionais à biologia da olfação nesse modelo animal. L. macrocephalus apresenta células epidérmicas produtoras da substância de alarme, típicas de Ostariophysi de água doce, e repertórios comportamentais defensivos à estimulação com o extrato de pele de co-específico, caracterizado pelo freezing comportamental. Comprovou-se nesse estudo que o sistema olfatório é essencial para mediar as respostas comportamentais ao extrato de pele de co-específico. Porém, é a primeira vez que um estudo demonstra que não é necessária a integridade total do bulbo olfatório para que ocorra respostas de alarme. Baseando-se na divisão morfofuncional do sistema olfatório de peixes e em nossos estudos neuroanatômicos, aventamos que os neurônios sensoriais que medeiam a resposta de alarme em L. macrocephalus terminam e fazem sinapses com neurônios de segunda ordem que compõem o trato olfatório lateral, sendo este responsável por mediar as respostas comportamentais ao extrato de pele de co-específico nessa espécie. Nossos achados neuroanatômicos demonstram que as informações do bulbo olfatório trafegam através de dois tratos olfatórios, o medial e o lateral, ipsi e contralateralmente para núcleos telencefálicos bem como para o bulbo olfatório contralateral, sendo que as conexões ipsilaterais são mais densas que as contralaterais. As fibras eferentes do bulbo olfatório em $L$. macrocephalus distribuem-se em quatro campos olfatórios terminais telencefálicos: medial, que compreende o telencéfalo ventroventral, ventrodorsal (incluindo as subdivisões dorsal, intermediária e ventral), ventrosupracomissural, dorsocentral e neuropilas de células adjacentes a esses núcleos; intermediário, que compreende o telencéfalo ventrocentral e ventroposcomissural; lateral, que compreende a região dorsolateral (sobretudo as porções ventral e dorsal da subdivisão ventral) e; posterior, composta pelo telencéfalo dorsoposterior e dorsodorsal. O bulbo olfatório por sua vez recebe aferências do telencéfalo ipsilateral, além de aferências oriundas do bulbo contralateral, sendo conduzidas tanto pelas fibras que compõem o trato olfatório medial como as que compõem o trato olfatório lateral. Entretanto, estudos neuroetológicos envolvendo lesões restritas a determinados núcleos telencefálicos são necessários para comprovar a participação dos campos terminais olfatórios telencefálicos sobre o processamento do extrato de pele de coespecífico.

\section{CARACTERIZAÇÃO DO "NÚCLEO G" EM UM PEIXE ELÉTRICO DE CAMPO FRACO E SUA PAR- TICIPAÇÃO NA VIA DE TRANSFERÊNCIA DA INFORMAÇÃO VISUAL PARA O HIPOTÁLAMO}

\section{Ana Catarina Casari Giassi}

Orientadora: Profa. Dra. Anette Hoffmann

Tese de Doutorado apresentada em 11/08/2008

O presente estudo tem como objetivo caracterizar o "núcleo $\mathrm{G}$ " em um peixe elétrico de campo fraco, o Gymnotus cf. carapo, a fim de conhecer seu papel no processamento sensorial, bem como identificar algumas das estruturas integrantes do processamento visual e estabelecer as relações evolutivas entre as vias de transferência dessas informações em gimnotiformes e outros teleósteos.

Além disso, as projeções da retina foram examinadas a fim de auxiliar na identificação e descrição das áreas pré-tectais da espécie em questão, facilitando comparações com o pré-tecto de outras espécies. De maneira geral, as projeções retinofugais observadas em Gymnotus se assemelham às observadas em outros teleósteos, e a presença de projeções retinopetais sugere que existe um controle da sensibilidade visual nesses animais.
Dados histoquímicos e citoarquitetônicos sugerem que o núcleo G seja parte do complexo glomerular, e que seja contínuo com o grupo de células ventromedial da subdivisão medial do complexo pré-glomerular. Além disso, esses dados sugerem que caudalmente, o "núcleo G" corresponde à estrutura descrita como corpos mamilares por outros autores. Entretanto, a origem do "núcleo G' no tubérculo posterior só poderá ser confirmada a partir de estudos ontogenéticos, já que os complexos glomerular e pré-glomerular parecem agrupar estruturas de diferentes origens.

Adicionalmente, técnicas de tracejamento neuronal foram utilizadas para a descrição e análise das suas conexões. As conexões observadas sugerem que o "núcleo G" faz parte do circuito envolvido na integração sensóriohumoral-comportamental que ocorre no lobo inferior do hipotálamo em resposta a informações visuais e eletrosensoriais provenientes do pré-tecto, e que essa via de processamento assemelha-se ao padrão de organização prétectal simples, descrito em ciprinídeos.

\section{ESTUDO EXPERIMENTAL DA DESCOMPRESSÃO DO CANAL MEDULAR EM RATOS ASSOCIA- DA À INJEÇÃO INTRATECAL DE NOC12}

Valéria Ferreira Garcez

Orientadora: Profa. Dra. Elaine A. Del-Bem Guimarães Belluz

Tese de Doutorado apresentada em 14/08/2008
Foi investigado o efeito da lesão medular por compressão seguida por descompressão cirúrgica e administração intratecal do doador de óxido nítrico, N-Ethyl-2-(1-ethyl- 
2-hydroxy-2-nitrosohydrazino) ethanamine, NOC12, em ratos. A recuperação sensório-motora foi analizada por meio da escala de avaliação locomotora de Basso Beattie e Bresnahan (BBB) e teste de retirada de cauda. Também foram estudadas a expressão da sintase do óxido nítrico neuronal (nNOS) e a extensão da lesão na medula espinal. Ratos Wistar foram divididos nos grupos $(\mathrm{n}=5-15)$ laminectomia (T10, Lam); compressão (Comp), onde o estreitamento do canal vertebral em $35 \%$ foi induzido por implante de espaçador; e descompressão (Decomp), onde a compressão foi seguida de cirurgia para retirada do espaçado r seis horas após inserção. Um dia depois, cada grupo foi subdividido em 3 subgrupos que receberam injeção intratecal (51J1/1 min.) de veiculo, NOC12-30 ou 300nM. A recuperação funcional foi avaliada um dia antes e no primeiro, quinto e sétimo dia pós-operatório (dpo). A compressão medular por estreitamento do canal vertebral resultou em déficit motor significativo $(\mathrm{P}<0.05)$. A descompressão favoreceu a melhora significativa da função, aumentando a pontuação na escala BBB (Lam, Comp e Decomp, respectivamente: 1 dpo- $21 \pm 0 ; 8 \pm 1,14 \pm 0$; 5 dpo- $21 \pm 0,11 \pm 0,17 \pm 1$; 7dpo$21 \pm 0,12 \pm 1,18 \pm 1 ; \mathrm{P}<0.05)$. A Decomp associada ao NOC12$30 \mathrm{nM}$ aumentou a pontuação BBB e reduziu significativamente a extensão da lesão tecidual no quinto e sétimo dpo $(\mathrm{P}<0.05)$. Não houve. modificação na densidade de neurônios NOSn+ nos cornos dorsal e ventral da medula sétimo dpo. O NOC12-30nM induziu uma redução no índice de antinocicepção no grupo Lam 7dpo $(\mathrm{P}<0.05)$. Em conclusão, este estudo demonstrou que o estreitamento do canal vertebral em $35 \%$ em ratos induz déficit motor e a descompressão seis horas após é capaz de auxiliar na recuperação motora. Além disso, a descompressão associada à liberação local de óxido nítrico exógeno durante a lesão aguda promove melhora adicional na recuperação da função motora e redução da extensão da lesão.

\section{GENÉTICA}

\section{PERFIL DA EXPRESSÃO DOS GENES DE MIGRAÇÃO E ADESÃO CELULAR EM TUMORES NEUROEPITELIAIS DE ADULTOS E CRIANÇAS}

\author{
Fábio José Nascimento Motta \\ Orientador: Prof. Dr. Luiz Gonzaga Tone \\ Tese de Doutorado apresentada em 28/07/2008
}

As metaloproteinases de matriz, seus inibidores teciduais e as caderinas possuem importância crítica na evolução e progressão dos tumores cerebrais. Estudos têm demonstrado que alterações na expressão dos genes de migração e adesão celular são envolvidas na evolução clínica dos tumores neuroepiteliais.

Métodos: Avaliamos 81 tumores, sendo 62 astrocitomas: 21 de grau I, 10 de grau II, 10 de grau III e 21 de grau IV - glioblastoma) e 19 meduloblastomas, de pacientes admitidos no HCFMRP-USP e mais cinco amostras de tecido cerebral não neoplásico. A expressão dos genes $M M P-2$, MMP-3, MMP-9, MMP-14, TIMP-1, -2, -3, -4 e CDH1 foi mensurada por PCR em Tempo Real. Para analises estatísticas utilizamos os testes Kruskal-Wallis e Kaplan-Meir.

Resultados: A expressão dos genes $M M P-2$ e $M M P$ 3 não diferiram entre os tumores estudados. Expressão ele- vada de $M M P-9$ e $M M P-14$ foi detectada nos tumores astrocíticos de alto grau de malignidade (III e IV), em relação aos tumores de baixo grau e meduloblastomas $(P=0,001$, $P=0,006$, respectivamente). Diferenças na expressão TIMP1 foram observadas apenas entre astrocitomas de alto grau e meduloblastomas $(P<0,0001)$. Astrocitomas de baixo grau apresentaram maior expressão dos genes TIMP-2, TIMP-3, TIMP-4 e CDHI $(P=0,001, P<0,0001 ; P=0,0006$ e $P=0,0002)$ frente aos demais tumores, sugerindo que essas moléculas possuam um efeito de contenção da invasão tumoral. $C D H 1$ foi preferencialmente expresso no tecido não neoplásico frente aos astrocitomas de grau I $(P=0,047)$. Análises de sobrevida demonstraram que hiperexpressão de $M M P-9$ nos glioblastomas é relacionada à sobrevida menor $(P=0,007)$. Análises posteriores demonstraram que esse é um fator prognóstico independente $(P=0,013)$.

Conclusões: A elevação da expressão das $M M P s$, redução de TIMPs e $C D H 1$ parecem ser determinantes para a agressividade dos tumores neuroepiteliais, o que faz dessas vias potenciais alvos terapêuticos para novas estratégias no combate a essas neoplasias. 


\section{CITOGENÉTICA MOLECULAR APLICADA AO DIAGNÓSTICO PRÉ-IMPLANTACIONAL DE ANEUPLOIDIAS CROMOSSÔMICAS}

\section{Juliana Fabrícia Cuzzi}

Orientadora: Profa. Dra. Lucia Regina Martelli

Tese de Doutorado apresentada em 13/08/2008

Os seres humanos apresentam uma baixa capacidade fértil, quando comparados a outras espécies. Casais com fertilidade comprovada e que tentam ter outro filho, têm somente $25 \%$ de chance de sucesso por ciclo menstrual. $\mathrm{O}$ alto índice de morte embrionária contribui de forma significativa para essa baixa fertilidade. Vários fatores estão relacionados com a perda gestacional prematura, no entanto as anomalias cromossômicas são as mais importantes. Aproximadamente $70 \%$ dos embriões morfologicamente normais apresentam alterações cromossômicas, sendo que mais de $50 \%$ dos embriões em estágio pré-implantacional possuem células aneuplóides. O Diagnóstico Genético Préimplantacional é uma forma precoce de diagnóstico prénatal na qual é possível detectar anomalias genéticas em oócitos e em embriões humanos. A maioria dos diagnósticos foi obtida por meio da técnica de FISH (hibridação in situ fluorescente) com o intuito de detectar anomalias de cromossomos específicos, existindo porém, limitações em relação ao número de cromossomos que podem ser avaliados simultaneamente. A hibridação genômica comparativa (CGH) não requer a fixação do núcleo da célula embrionária e é capaz de detectar perdas e ganhos de seguimentos cromossomos maiores do que $10 \mathrm{Mb}$ em um único experimento.
O objetivo deste trabalho foi estabelecer o Diagnóstico Genético Pré-implantacional de aneuploidias utilizando dois métodos de investigação citogenética molecular: (1) CGH em oócitos (MII) e nos primeiros corpúsculos polares correspondentes (1CP) e (2) FISH em blastômeros obtidos de embriões humanos em estágio de clivagem. Na primeira parte deste estudo, realizamos com êxito, a análise por CGH de 16 células (MII+1CP) procedentes de oito oócitos maduros e não criopreservados. Observou-se uma taxa de aneuploidias de $25 \%$ e os cromossomos envolvidos foram o 16, 19 e 22. Estes dados sugerem uma associação entre o tamanho do cromossomo e a frequiência de aneuploidias, o que está de acordo com relatos anteriores da literatura. No segundo capítulo desta tese, descrevemos um novo protocolo de FISH para PGD. Com o objetivo de ampliar o número de cromossomos analisados em cada blastômero, aplicamos um procedimento de hibridações repetidas que permitiu identificar 15 cromossomos por núcleo $(n=14)$. A porcentagem de perda nuclear foi de $35,7 \%$ após a primeira etapa de FISH e 50\% após a segunda hibridação. Encontramos um índice de aneuploidias de $100 \%$ que pôde ser relacionado às características morfológicas e de desenvolvimento dos embriões. De acordo com os resultados obtidos concluímos que as técnicas de CGH e o protocolo de FISH utilizando sondas de oligonucleotídeos foram eficientes, possibilitando maior acurácia do diagnóstico citogenético préimplantacional.

\section{COORDENAÇÃO DAS RESPOSTAS CELULARES AO ESTRESSE GENOTÓXICO CAUSADO PE- LOS RAIOS-GAMA EM LINHAGENS DE GLIOBLASTOMA PROFICIENTES E MUTANTES PARA O GENE TP53}

\section{Paulo Roberto D'Auria Vieira de Godoy \\ Orientadora: Profa. Dra. Elza Tiemi Sakamoto Hojo \\ Dissertação de Mestrado apresentada em 15/08/2008}

As radiações ionizantes (RI) bloqueiam a proliferação e levam à morte celular pela indução de lesões no DNA, principalmente quebras de fita simples e duplas (DSBs). Essas lesões são detectadas e processadas por uma complexa rede de sinalização celular. No entanto, em glioblastomas, a heterogeneidade genética leva a uma sinalização celular alterada, diversificando as respostas à radioterapia entre tumores de diferentes pacientes. Neste estudo, foram avaliadas respostas celulares à radiação ionizante $\left(\mathrm{Co}^{60}\right)$ em quatro linhagens de glioblastoma (GBM), diferenciadas principalmente pelo status do gene TP53 (mutante para as linhagens T98G e U251 e selvagem para U343 e U87). Foram avaliados parâmetros como sobrevivência clonogênica
(15 dias após o tratamento) e citotoxicidade ( 24 h e 5 dias, kit XTT), apoptose (24, 48 e $72 \mathrm{~h})$, ensaio de cometa (0, 0,5, 1,2 e 6 h), e análise de perfis de expressão por cDNA microarrays (0,5 e 6 h) nas linhagens T98G, U343, U87 e U251. A expressão transcricional por qPCR em tempo real $(6 \mathrm{~h})$ e Western blot $(6 \mathrm{~h})$ foram avaliadas somente para T98G e U343. As doses variaram de 2 a 16 Gy de acordo com o experimento. Em 24 h após a RI, os resultados do teste de citotoxicidade (kit XTT) mostraram uma ausência de resposta, enquanto que, em 120 h (5 dias), houve uma redução significativa nas taxas de sobrevivência. As curvas de sobrevivência clonogênica indicam padrões similares para três linhagens (U343MG, T98G e U251), enquanto que a U87 apresentou taxas de sobrevivência maior do que as outras linhagens até $8 \mathrm{~Gy}$, sob as doses de 2, 4, 8 e 16 Gy.Foram observados diferentes padrões de indução de apoptose nas células selvagens (U343 e U87) e mutantes (T98G e 
U251) para TP53, com baixas taxas de apoptose nas proficientes e altos níveis de indução de apoptose nas mutantes, principalmente nas doses de 8 e 16 Gy (48 e 72 horas). O Ensaio do Cometa mostrou que todas as linhagens sofreram redução dos danos no DNA (baseado no Tail Moment), dependendo do tempo de colheita, até o reparo completo em 6 h. Os dados da qPCR mostraram que a transcrição dos genes TP53, ATM, PRKDC alternaram do estado reprimido (4 Gy) para o estado induzido (8 Gy), exceto o gene BRCA1, na linhagem $T 98 G$, induzido em 4 e 8 Gy. O ensaio Western blot mostrou uma indução dependente de dose para o gene TP53, na linhagem U343, enquanto que a T98G não mostrou indução, mas apresentou nível basal da proteína. A análise dos perfis de expressão gênica efetuada pelo método de cDNA microarrays gerou uma grande quantidade de dados interessantes. Primeiramente, pela aplicação do programa $\mathrm{MEV}$, o agrupamento hierárquico dos resultados de expressão mostrou perfis de expressão comuns ou diferentes, dependendo do grupo de genes, para as linhagens estudadas, caracterizando as mesmas. Além disso, observou-se uma evidente distinção entre as células irradiadas e não irradiadas. A análise dos resultados gerados realizada pelo método SAM (Significance Analysis of Microarrays) mostrou que as linhagens proficientes para o gene TP53 apresentaram 62 genes significativamente modulados ( 5 induzidos e 57 reprimidos) no tempo de 30 min após a irradiação, en- quanto que as mutantes apresentaram 21 genes (11 induzidos e 10 reprimidos) no mesmo tempo. Em 6 h, foram modulados 88 (20 induzidos e 68 reprimidos) e 59 genes ( 16 induzidos e 43 reprimidos), para as linhagens proficientes e mutantes, respectivamente. Várias funções foram moduladas, como diferenciação celular, adesão celular, ciclo celular, apoptose, reparo do DNA, transdução de sinal etc., sendo que muitas dessas funções foram comuns, ou exclusivas às linhagens mutantes ou proficientes, nos tempos de 30 min e $6 \mathrm{~h}$. A linhagem U87 apresentou um maior grau de radiorresistência entre as linhagens. Algumas funções biológicas moduladas nessa linhagem podem estar correlacionadas à radiorresistência, tais como: modulação de atividade MAPK (30 min e $6 \mathrm{~h}$ ), crescimento celular (30 min), resposta ao estresse (30 min e $6 \mathrm{~h}$ ), diferenciação celular (30 minutos), ciclo celular $(6 \mathrm{~h})$, adesão celular $(6 \mathrm{~h})$. Segundo a literatura, existe uma grande complexidade inerente à coordenação dos vários processos biológicos implicados nas respostas à irradiação das células. Mas sem dúvida, as informações obtidas no presente trabalho fornecem uma contribuição importante na elucidação de tais mecanismos, ainda pouco esclarecidos, além de apontar algumas vias de sinalização bloqueadas ou ativadas, em comum ou de forma diferencial para as linhagens GBM. Essas informações são relevantes na busca por alvos de intervenção terapêutica, seja por inibição farmacológica ou molecular.

\section{CARACTERIZAÇÃO DA REGIÃO CODIFICADORA E ANÁLISE DE EXPRESSÃO DE HEXAME- RINAS DURANTE O DESENVOLVIMENTO DE Apis mellifera}

\section{Juliana Ramos Martins \\ Orientadora: Profa.Dra. Márcia Maria Gentile Bitondi \\ Dissertação de Mestrado apresentada em 29/08/2008}

Os cDNAs dos genes codificadores das hexamerinas HEX 70a, HEX 70c e HEX 110 de Apis mellifera foram sintetizados a partir de RNA total, clonados e suas regiões codificadoras foram totalmente seqüenciadas. As análises in silico dos produtos de tradução mostraram que as respectivas subunidades protéicas contêm os domínios conservados N, M e C, típicos de hemocianinas, e que em HEX 110, mas não nas outras subunidades, o domínio $\mathrm{C}$ foi interrompido pela inserção de uma sequência repetitiva de aminoácidos. Análises de similaridade indicaram que os genes codificadores de hexamerinas derivaram de eventos de duplicação e diversificação a partir de um gene ancestral, resultando em múltiplos parálogos. Nossas análises também evidenciaram que HEX 110 é uma proteína rica em glutamina/ácido glutâmico e que HEX 70a e HEX 70c são compostas por mais de $15 \%$ de aminoácidos aromáticos e, portanto, integram a classe das arilforinas. A expressão temporal destes genes, e também do gene codificador de outra hexamerina de $A$. mellifera, hex $70 b$, previamente caracteri- zado, foi analisada qualitativa e quantitativamente durante o desenvolvimento de operárias, rainhas e zangões. Concomitantemente, a abundância dos respectivos polipeptídeos no corpo gorduroso ou hemolinfa foi examinada por SDS-PAGE ou Western Blot. Os quatro genes de hexamerinas se expressam no corpo gorduroso de operárias, rainhas e zangões principalmente durante o estágio larval. A modulação da expressão destes genes mostra semelhanças durante a transição larval-pupal de operárias, rainhas e zangões, com altos níveis de transcritos no último estágio larval e baixos níveis no início da fase pupal. No entanto, a quantidade relativa de transcritos de hex 70a, hex $70 b$ e hex 110 na fase de alimentação do último estágio larval (L5F) é significantemente menor nas rainhas que nas operárias, o que sugere participação das respectivas proteínas no processo de diferenciação de castas. Durante o estágio larval, as quatro diferentes subunidades de hexamerinas são armazenadas na hemolinfa onde, aparentemente, cumprem a função de proteínas de estocagem e, portanto, constituem fonte de aminoácidos para utilização em processos inerentes ao desenvolvimento pupal. No entanto, a expressão de hex $70 a$ se estende até ao estágio adulto de operárias, rainhas e zangões, e neste estágio, as fêmeas e os zangões 
exibem perfis distintos de expressão. No corpo gorduroso de operárias, mas não no de rainhas e zangões, a expressão de hex 110 também ocorre durante o estágio adulto. A expressão de hex $70 a$ e hex 110 no corpo gorduroso mostrouse limitada pela disponibilidade de nutrientes: operárias alimentadas com uma dieta protéica apresentaram níveis significantemente maiores de ambos transcritos que aquelas que receberam dieta desprovida de proteínas, assim evidenciando que os processos de transcrição e tradução são nutricionalmente regulados. Além disto, os níveis de transcritos de hex 70 a e hex 110 aumentam no corpo gorduroso de abelhas operárias portadoras de ovários ativos, sugerindo que estes genes têm função associada à reprodução. Em A. mellifera, o corpo gorduroso não é o único sítio de expressão dos genes de hexamerinas. Transcritos de hex $70 \mathrm{a}$, hex $70 b$ e hex 110 foram detectados também nas gônadas em desenvolvimento de operárias, rainhas e zangões, sugerindo uma função na diferenciação dos ovários e maturação dos testículos. Nossos resultados indicam que as hexamerinas codificadas por estes genes têm funções alternativas no ciclo de vida de abelhas $A$. mellifera, além de servir como fonte de aminoácidos para a metamorfose.

\section{ESTUDO GENÉTICO-CLÍNICO DE DEFICIENTES MENTAIS INSTITUCIONALIZADOS}

\section{Lisandra Mesquita Batista}

Orientador: Prof. Dr. João Monteiro de Pina Neto

Dissertação de Mestrado apresentada em 12/09/2008

A Deficiência Mental (DM) é uma preocupação para a saúde pública e a sociedade, sendo a pesquisa de sua etiologia um desafio para a medicina. Estima-se que $10 \%$ da população em países em desenvolvimento, são portadores de algum tipo de deficiência, sendo que metade destes são portadores de deficiência mental. Com o objetivo de se estabelecer o diagnóstico clínico e etiológico da DM em uma população de deficientes mentais institucionalizados, foram avaliados 200 pacientes das APAEs de Altinópolis e Serrana. Para isso, foi realizado um exame genético-clínico com construção dos heredogramas e exames complementares, como o de imagem do Sistema Nervoso Central (SNC), exames metabólicos, cariótipo e análise molecular para as síndromes do FRAXA e FRAXE. Esses exames complementares mostraram-se relevantes e com valor diagnóstico. Foram selecionados para exame de cariótipo 91 pacientes, entre eles as síndromes reconhecidas, as prováveis síndromes e os casos indefinidos, sendo observado $30 \%$ de alterações; para triagem molecular FRAXA e FRAXE foram selecionados os casos do sexo masculino sem causa definida, o que correspondeu a 35 exames, observando-se $1(2,8 \%)$ caso positivo; para triagem de erros inatos do metabolismo, 17 casos suspeitos foram selecionados e foi notado alteração em 35\%; para imagem do SNC, os casos com sintomas neurológicos, alterações cranianas e casos sem definição de DM foram selecionados e observou-se $69 \%$ de anormalidades. Os pacientes foram classificados quanto a seu diagnóstico, clinicamente e etiologicamente. Classificou-se, clinicamente, $23 \%$ dos pacientes com DM com anomalias múltiplas, 4\% DM com malformação do SNC isolada, 3\% DM e erros inatos do metabolismo, $42 \%$ com DM de causa ambiental, $1 \%$ DM e disfunção do SNC, 7\% DM aparentemente puro e 20\% DM não classificado. Quanto a etiologia, $28 \%$ dos pacientes apresentaram DM de causa genética (14\% anomalias cromossômicas e 14\% anomalias gênicas), $42 \%$ de causa ambiental, $4 \%$ heterogêneo, $2 \%$ esporádico, $1 \%$ multifatorial e $23 \%$ indefinido. O perfil desta amostra evidenciou uma prevalência do sexo masculino com uma razão de 1.3 M:1 F. Observou-se consanguinidade em 1,5\% dos casos. Houve predomínio de DM moderada $(48,5 \%)$ e grave $(22,5 \%)$. Estabelecer o diagnóstico etiológico de DM é complexo e continua sendo um desafio para os diferentes especialistas, mas mostra-se essencial principalmente para definir estratégias de prevenção e manejo das deficiências mentais

\section{ANÁLISE GENÉTICO-QUANTITATIVA DE CARCTERÍSTICAS DE PRECOCIDADE SEXUAL NA RAÇA NELORE}

\section{Pedro Alejandro Vozzi}

Orientador: Prof. Dr. Raysildo Barbosa Lôbo

Tese de Doutorado apresentada em 17/09/2008

Utilizou-se inferência Bayesiana para estimar componentes de variância e parâmetros genéticos para a característica Probabilidade de Parto Precoce (3P), Idade ao Primeiro Parto (IPP), Perímetro Escrotal aos 365,450 e 550 dias
(PE365, PE450 e PE550), Crescimento Testicular entre os 365 e 450 dias de idade (CT 365-450) e entre os 450 e 550 dias de idade (CT 450-550) em animais da raça Nelore do Programa de Melhoramento Genético da raça Nelore (PMGRN). Modelos estatísticos que contemplem a estação de nascimento das novilhas, classe de idade da novilha ao parto e peso da mesma à desmama poderiam ser adequados para a utilização da característica nas avaliações genéticas. 
Independentemente do modelo, a característica $3 \mathrm{P}$ apresentou estimativas de herdabilidade próximas a $50 \%$ indicando que a utilização como critérios de seleção deveria responder eficiente à seleção. Nas análises multivariadas, as distribuições posteriores médias das estimativas de herdabilidade obtidas entre as características 3P, PE365, PE450, PE550, CT 365-450 foram de média a alta magnitude. A IPP e o (T 450-550 apresentaram menores valores de variabilidade genética. As maiores correlações genéticas entre $3 \mathrm{P}$ e IPP com os perímetros escrotais ocorreram aos 450 e 365 dias de idade respectivamente, indicando que possi- velmente seja esta a melhor idade para selecionar machos jovens com o objetivo de melhorar a precocidade sexual dos rebanhos. A correlação genética obtida entre 3P e IPP com Crescimento Testicular entre as diferentes idades sugerem que o crescimento testicular entre os 365 e 450 dias de idade estaria relacionado aos eventos fisiológicos associados à puberdade precoce. A IPP e a $3 \mathrm{P}$ apresentaram correlações genética favoráveis, próximas a $-90 \%$, indicando que a IPP pode ser utilizada como critério de seleção para precocidade sexual embora um considerável efeito ambiental afete a expressão da característica.

\section{BIOLOGIA MOLECULAR DE GENES ENVOLVIDOS NO METABOLISMO DO HORMÔNIO JUVE- NIL DE Apis mellifera}

\begin{abstract}
Aline Mackert dos Santos
Orientadora: Profa. Dra. Zilá Luz Paulino Simões

Tese de Doutorado apresentada em 23/09/2008
\end{abstract}

O Hormônio Juvenil (HJ) é um sesquiterpenóide que participa de diversas funções do ciclo de vida de insetos. Em Apis mellifera o HJ está envolvido também com o processo de diferenciação de castas e polietismo etário. Neste trabalho, genes participantes da degradação e das vias de síntese do HJ nos corpora allata (CA) foram identificados a partir das seqüências disponibilizadas pelo sequenciamento do genoma de A. mellifera. A identificação destes genes baseou-se em análises funcionais, como interferência por RNA fita dupla, similaridade entre seqüências, expressão tecido-específica e busca por motivos conservados. Análises de quantificação dos transcritos destes genes revelaram padrões condizentes com os títulos de HJ e mostraram que o balanço entre as vias de síntese e degradação deste hormônio age em conjunto para regular os títulos de HJ. Uma importante associação entre a degradação do HJ pelas enzimas esterase do HJ e epóxido hidrolase do HJ com o processo de diferenciação dos ovários, que ocorre durante o estágio larval, foi estabelecida. Estas enzimas parecem atuar ativamente na manutenção dos níveis de HJ durante o processo de diferenciação de castas. A alimentação mostrou ser um processo de suma importância sobre o metabolismo do HJ durante a vida adulta de operárias, em adição ao controle exercido pela alimentação já descrito durante o período larval, que leva à diferenciação de castas distintas. A execução deste trabalho contribuiu de maneira significativa para o conhecimento deste sistema instigante que controla toda a homeostasia em uma colônia do inseto social, Apis Mellifera.

\section{GINECOLOGIA E OBSTETRÍCIA}

\section{MARCADORES PRECOCES DE DOENÇA CARDIOVASCULAR EM MULHERES COM SÍNDROME DOS OVÁRIOS POLICÍSTICOS}

\section{Gustavo Mafaldo Soares}

Orientador: Prof. Dr. Rui Alberto Ferriani

Dissertação de Mestrado apresentada em 08/08/2008

Introdução: A síndrome dos ovários policísticos (SOP) é a endocrinopatia mais comum em mulheres no menacme, com prevalência variando de 5 a 10\%. A SOP está associada à elevação do risco cardiovascular e eventos metabólicos adversos, incluindo obesidade, resistência à insulina, dislipidemia e inflamação crônica de baixo grau. Apesar dos fatores de risco cardiovascular serem mais prevalentes em mulheres com SOP, não existe evidência científica de maior incidência de doença cardiovascular (DCV) nestas mulheres. Vários estudos reportaram alterações em marcadores de risco para DCV na SOP, porém ainda não foram determinados quais os marcadores ideais para a detecção precoce da DCV.

Objetivo: Avaliar a presença de marcadores preco- 
ces de DCV em mulheres jovens e não-obesas com SOP.

Casuística e Métodos: Foram incluídas 39 pacientes com SOP e 50 mulheres saudáveis, com ciclos menstruais regulares e pareadas por idade e índice de massa corporal (IMC). Através da ultra-sonografia foram avaliados os seguintes marcadores de DCV: índice de rigidez da artéria carótida comum, distensibilidade da artéria carótida comum, espessura da camada íntima-média da artéria carótida comum (IMT) e dilatação mediada pelo fluxo da artéria braquial (DMF). Foram avaliadas ainda variáveis antropométricas, hormonais e marcadores de inflamação em todas as participantes.

Resultados: A idade e o IMC nas mulheres com SOP não apresentaram diferença quando comparados às mulheres do grupo controle $(24,5 \pm 3,8$ anos vs $24,5 \pm 5,1$ anos, $\mathrm{p}=0,6 ; 22,7 \pm 3,2 \mathrm{Kg} / \mathrm{m}^{2}$ vs $23,1 \pm 3,1 \mathrm{Kg} / \mathrm{m}^{2}$, respectivamente). $\mathrm{O}$ índice de rigidez da carótida comum foi mais elevado no grupo SOP comparado ao grupo controle $(3,72 \pm$
0,96 vs 3,36 $\pm 0,96, p=0.04$, respectivamente) e a distensibilidade da artéria carótida comum foi menor nas pacientes com SOP em comparação àquelas do grupo controle $(0,31 \pm$ 0,08 vs $0,35 \pm 0,09, p=0,02$, respectivamente). As pacientes com SOP apresentaram maior circunferência da cintura, testosterona total e free androgen index (FAI) em relação ao grupo controle $(78,1+10,0 \mathrm{~cm}$ vs $71,5+7,2 \mathrm{~cm} \mathrm{p}=0,001$ $88,1+32,4 \mathrm{ng} / \mathrm{dL}$ vs $57,1+21,2 \mathrm{ng} / \mathrm{dL}, \mathrm{p}<0,0001$ e $12,7+$ 15,7 vs $4,7+2,3, p=0,003$, respectivamente), enquanto a sex hormone binding globulin (SHBG) mostrou-se reduzida na SOP quando comparada ao grupo controle $(37,9+19,1 \mathrm{nmol} /$ L vs 47,8 + 18,3 , p=0,01). As demais variáveis não diferiram entre os dois grupos.

Conclusão: Nosso estudo demonstra que mulheres jovens com SOP apresentam alterações na elasticidade vascular mesmo na ausência de clássicos fatores de risco para DCV, como: resistência à insulina, hipertensão ou obesidade.

\section{EFEITOS DA METFORMINA NOS NÍVEIS SÉRICOS DE INSULINA, DE HORMÔNIO ANTI- MULLERIANO E NO HIPERANDROGENISMO EM PACIENTES COM SÍNDROME DOS OVÁRI- OS POLICÍSTICOS}

\section{Areana Diogo Nascimento}

Orientadora: Profa. Dra. Rosana Maria dos Reis

Dissertação de Mestrado apresentada em 08/09/2008

A síndrome dos ovários policísticos (SOP) constitui a causa mais freqüente de infertilidade, anovulação e hiperandrogenismo atualmente. Sua fisiopatogenia é em parte obscura. O hormônio anti-mülleriano (HAM), uma glicoproteína produzida pelas células da granulosa dos folículos pré-antrais e folículos antrais pequenos, parece exercer papel fundamental para seu surgimento, exacerbando o hiperandrogenismo intra-folicular e interferindo no mecanismo de seleção do folículo dominante. Além das alterações ovulatórias, há repercussões metabólicas decorrentes da síndrome, como a resistência à insulina (RI), que afeta entre 45 a $70 \%$ das mulheres com SOP em idade reprodutiva. Estratégias para aumentar a sensibilidade à insulina poderiam reduzir o impacto reprodutivo e metabólico da RI. Entre elas, destaca-se a metformina, uma droga anti-diabética oral, cuja utilização levaria a uma melhora dos padrões metabólicos e restabelecimento da ovulação. No presente estudo, foram avaliados a relação entre os níveis séricos de HAM e resistência insulínica antes e após o tratamento com metformina, comparados os níveis séricos de HAM na fase folicular precoce entre pacientes com e sem SOP e correlacionados os níveis de HAM com os níveis séricos de insulina, gonadotrofinas e androgênios. Foram realizadas dosagens séricas de HAM, androgênios e gonadotrofinas em 36 pacientes (16 com SOP e resistência insulínica e 20 eumenorreicas, sendo grupos pareados quanto à idade e índice de massa corpórea). No grupo SOP, foram avaliados níveis de HAM, insulina, glicemia e QUICKI (quantitative insulin check index) antes e depois do tratamento com metformina $1500 \mathrm{mg} /$ dia por oito semanas. Foram encontrados níveis de HAM mais elevados no grupo SOP do que no grupo controle $(49,9 \pm 6,1 \mathrm{pmol} / \mathrm{L}$ versus $4,5 \pm 2,1 \mathrm{pmol} / \mathrm{L}, \mathrm{p}$ $<0,0001)$, assim como os níveis de hormônio luteinizante (LH) $(10,3 \pm 1,5 \mathrm{mUI} / \mathrm{L}$ versus 3,5 $\pm 0,5 \mathrm{mUI} / \mathrm{L}, \mathrm{p}=0,0004)$, testosterona $(64,9 \pm 5 \mathrm{ng} / \mathrm{mL}$ versus $41,1 \pm 4,7 \mathrm{ng} / \mathrm{mL}, \mathrm{p}=0,0017)$ e 17-hidroxiprogesterona (17OHP) ( $90 \pm 16,8 \mathrm{ng} / \mathrm{ml}$ versus $49,1 \pm 6,6 \mathrm{ng} / \mathrm{ml} ; \mathrm{p}=0,03)$. Nas pacientes com SOP, houve correlação positiva forte entre os níveis de HAM pré-tratamento e testosterona (coeficiente $\mathrm{r}$ de Pearson - R - de 0,83; $\mathrm{p}<0,0001)$. Também foi encontrada correlação positiva e significativa entre HAM e LH $(\mathrm{R}=0,51 ; \mathrm{p}=0,04)$. As demais variáveis não apresentaram correlação significativa com o HAM pré-tratamento. Após o tratamento, houve redução significativa dos níveis de insulina $(16,4 \pm 2,6 \mathrm{mUI} / \mathrm{ml}$ versus $12 \pm 1,9 \mathrm{mUI} / \mathrm{ml} ; \mathrm{p}=0,0132$ ). Os níveis de HAM tiveram redu-

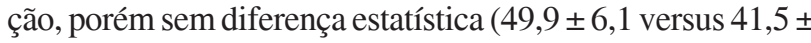
5,6 pmol/L; p=0,06). Houve redução significativa nos níveis de testosterona $(64,9 \pm 5 \mathrm{ng} / \mathrm{mL}$ versus $49,3 \pm 14 \mathrm{ng} / \mathrm{mL})$. A correlação do HAM com os níveis de testosterona não persistiu após o tratamento com a metformina $(\mathrm{R}=0,08 \mathrm{e} \mathrm{p}=0,76)$. Assim, a manutenção dos níveis séricos de HAM após o uso da metformina, mesmo com a comprovada melhora metabólica e redução dos níveis de gonadototrofinas sugere que o papel do HAM na SOP baseia-se num mecanismo intrínseco ovariano, independente do eixo hipotálmohipófise-ovário e não influenciado pela resistência insulínica. 


\section{ANÁLISE COMPARATIVA DO FUSO CELULAR E DAS CONFIGURAÇÕES CROMOSSÔMICAS DE OÓCITOS MATURADOS IN VITRO DE PACIENTES COM ENDOMETRIOSE E CONTROLE: ESTUDO PILOTO}

\author{
Ionara Diniz Evangelista Santos Barcelos \\ Orientadora: Profa. Dra. Paula Andrea de A.Salles Navarro \\ Dissertação de Mestrado apresentada em 26/09/2008
}

Objetivo: Avaliar o fuso meiótico e a distribuição cromossômica de oócitos maturados in vitro, obtidos de ciclos estimulados de mulheres inférteis com endometriose e fatores masculino e/ou tubário de infertilidade (grupo controle) e comparar as taxas de maturação in vitro (MIV) entre os dois grupos avaliados.

Método: Quatorze pacientes com Endometriose e 8 com fator tubário ou masculino, submetidas à estimulação ovariana para injeção intra-citoplasmática de espermatozóide (ICSI), foram selecionadas prospectiva e consecutivamente e divididas em grupos de estudo e controle, respectivamente. Oócitos imaturos (46 e 22, respectivamente, dos grupos endometriose e controle), foram submetidos à maturação in vitro (MIV). Oócitos que apresentaram a extrusão do primeiro corpúsculo polar foram fixados e corados para avaliação dos microtúbulos e cromatina por técnica de imunofluorescência. A análise estatística foi realizada utilizando o teste exato de Fisher, com significância estatística quando $\mathrm{p} \leq 0,05$.
Resultados: Não se observou diferença significativa nas taxas de MIV entre os dois grupos avaliados (45,6\% e $54,5 \%$, respectivamente, nos grupos endometriose e controle). A organização cromossômica e do fuso meiótico foi observada em 18 e 11 oócitos dos grupos endometriose e controle, respectivamente. No grupo endometriose, 8 oócitos $(44,4 \%)$ apresentavam-se como metáfase II (MII) normais, 3 (16,7\%) MII anormais; 5 (27,8\%) estavam em estágio de telófase I e $2(11,1 \%)$ sofreram ativação partenogenética. No grupo controle, 5 oócitos $(45,4 \%)$ apresentavam-se como MII normais, $3(27,3 \%)$ MII anormais, $1(9,1 \%)$ estava em estágio de telófase I e 2 (18,2\%) sofreram ativação partenogenética. Não se observou diferença significativa na percentagem de anomalias meióticas entre os oócitos em MII dos dois grupos avaliados.

Conclusões: Os dados do presente estudo não demonstraram diferença significativa nas taxas de MIV e nas proporções de anomalias meióticas entre os oócitos maturados in vitro, provenientes de ciclos estimulados de pacientes com endometriose, quando comparados aos controles. Todavia sugerem um retardo na conclusão da meiose I nos oócitos provenientes de portadoras de endometriose, pela maior proporção de oócitos em telófase I observada neste grupo.

\section{IMUNOLOGIA BÁSICA EAPLICADA}

\section{EXPRESSÃO DE HLA-G EM ESCLEROSE SISTÊMICA : ASSOCIAÇÃO COM POLIMORFISMOS GÊNICOS}

\section{Isabela Jubé Wastowski}

Orientador: Prof. Dr. Eduardo Antonio Donadi

Tese de Doutorado apresentada em 02/07/2008

A esclerose sistêmica (ES) é uma doença do tecido conectivo caracterizada por manifestações clínicas heterogêneas e de evolução variável. São características marcantes da ES a auto-imunidade e a inflamação, que afeta, sobretudo os vasos sanguíneos e suas diferentes camadas (vasculopatia), com fibrose intersticial e perivascular progressiva. Baseando-se na extensão do envolvimento cutâneo, pacientes com ES são classificados em duas variantes clí- nicas distintas (difusa e limitada). Fatores ambientais e genéticos têm sido associados à patogênese da ES, como os polimorfimos do complexo principal de histocompatibilidade (MHC). Embora os genes do MHC clássico tenham sido associados previamente à etiologia da ES, os polimorfismos e a expressão dos genes do MHC não-clássico não foram ainda avaliados na ES. O HLA-G é uma molécula nãoclássica de MHC classe I caracterizada por expressão restrita a certos tecidos e por exibir funções imuno-regulatórias, capazes de inibir a proliferação alogênica de linfócitos $\mathrm{T}$ antígeno-específicos, citotoxicidade de células natural killer e citotoxicidade de linfócitos T. Embora haja poucos estu- 
dos sobre a expressão de HLA-G em doenças auto-imunes, foi previamente demonstrado que a expressão de HLA-Gé induzida em doenças cutâneas crônico-inflamatórias, tais como a psoríase e a dermatite atópica, mas nunca em controles de pele normal. Em nosso estudo, nós avaliamos a expressão de HLA-G (transcritos e proteína). Além disso, nós também avaliamos o polimorfismo de $14 \mathrm{pb}$ do gene HLA-G e o polimorfismo do tipo SNP (single nucleotide polymorphism) +874 T/A do gene de INF- $\gamma$. Um grupo de 177 pacientes com ES e um grupo composto por 191 indivíduos saudáveis foram avaliados quanto as frequiências alélicas e genotípicas dos polimorfismos de INF- $\gamma$ e HLA-G. Trinta e quatro e 21 pacientes foram avaliados quanto a expressão de HLA-G por meio das metodologias de PCRreal-time e imunohistoquimica, respectivamente. Todas as análises estatísticas foram feitas utilizando-se o programa GraphPad Instat. Nossos resultados mostraram que não havia diferenças estatisticamente significantes nas frequiências alélicas e genotípicas no loco HLA-G quando comparado o grupo de pacientes com o grupo controle. A frequiência do alelo +874 A do loco INF- $\gamma$ foi significantemente maior no grupo de pacientes que apresentavam escore modificado de Rodnan maior que 12 ( $\mathrm{p}=0.034, \mathrm{OR}=1.5795 \%$ IC: 1.044 - 2.360) a genótipo T/T foi mais frequiente em pacientes com ES limitada $(\mathrm{P}=0,002 ; \mathrm{OR}=0,27 ; 95 \% \mathrm{IC}$ : 0,1140 $0,6686)$ quando ambos os grupos de pacientes foram comparados. Esse genótipo também foi significativamente mais frequiente em pacientes caucasianos, independentemente da variante da doença $(\mathrm{P}=0,009 ; \mathrm{OR}=0,8 ; 95 \% \mathrm{IC}$ : 0,6976$0,9207)$. Pacientes que apresentavam dispnéia $(\mathrm{P}=0,02$, $\mathrm{OR}=1,76 ; 95 \%$ IC: $1,074-2,904)$ e $\mathrm{CFV} \pm 70 \%(\mathrm{P}=0,01$, $\mathrm{OR}=1,79 ; 95 \% \mathrm{IC}: 1,235-2,562)$ tiveram maior frequiência do genótipo A/A. A expressão de HLA-G, quando avaliada nas amostras de pele de pacientes com ES foi observada primeiramente em células de epiderme, e em menor intensidade em células perivasculares. Não foi observada a expres- são de HLA-G em amostras de pele de indivíduos saudáveis. Ao se comparar a expressão de HLA-G entre o grupo de pacientes e o grupo controle obtemos $\mathrm{p}<0.0001$. Houve tendência de maior expressão de HLA-G entre indivíduos caucasianos com ES limitada $(\mathrm{p}=0.06)$. Além disso, pacientes que expressavam HLA-G tinham menor média de idade ao manifestarem a doença $(\mathrm{p}=0.046)$ e apresentavam menor escore modificado de Rodnan, do que aqueles pacientes que não expressavam HLA-G, independentemente da variável clínica. A expressão de HLA-G também foi correlacionada a menor frequiência de úlceras cutâneas vasculares $(\mathrm{p}=0.03)$, telangiectasias $(\mathrm{p}=0.008)$, poliartralgia inflamatória (tendência; $\mathrm{p}=0.08$ ) e envolvimento cardíaco (tendência; $\mathrm{p}=0.08)$. Durante 15 anos de seguimento clinico, 11 pacientes biopsiados (52\%) foram a óbito, sendo 8 mortes associadas à ES. A expressão de HLA-G foi significantemente maior em pacientes que tiveram maior sobrevida ( $\mathrm{p}$ $=0.03$ ) após 15 anos. As analises de PCR-Real-time mostraram que dentre os 34 pacientes estudados, 16 expressavam HLA-G. Esse grupo de pacientes não apresentavam úlceras digitais $(\mathrm{p}=0.002)$ e tinham menos telangiectasias $(\mathrm{p}=0.03)$, quando comparados ao grupo de pacientes que não expressava HLA-G. O genótipo de HLA-G previamente associado à menor produção da molécula (14bp inserção/inserção) não foi observado no grupo de pacientes que expressava HLA-G. Em conclusão, têm sido proposto que a expressão de HLA-G nos sítios inflamatórios contribui para o controle da lesão tecidual preservando a integridade do tecido. Nossos resultados sugerem que a expressão de HLA-G em pacientes com ES pode ser associada com a melhor evolução clínica da doença, bem como o polimorfismo +874 do loco de INF- $\gamma$ deve favorecer a maior transcrição e conseqüentemente maior produção da citocina, a qual tem efeito imunomodulatório na produção de colágeno. Não há estudos prévios avaliando a expressão de HLA-G e os polimorfismos no loco HLA-G e INF- $\gamma$ na ES.

\section{USO DE LINFÓCITOS B EM TERAPIA GÊNICA}

\section{William Roberto Schluchting}

Orientadora: Profa.Dra. Arlete A. Martins Coelho-Castelo Dissertação de Mestrado apresentada em 26/08/2008

Recentemente nosso grupo descreveu que os linfócitos B podiam capturar DNA plasmidial e expressar proteína in vivo após a vacinação gênica. Essas células apresentam uma maquinaria de produção protéica altamente eficiente, favorecendo o uso das mesmas na transferência de genes e expressão in vivo de proteínas. Desse modo, o objetivo do nosso trabalho foi utilizar os linfócitos B para mediar transferência de moléculas para animais. O plasmideo que codifica a proteína fluorescente verde (GFP) foi usado para padronizar a transfecção e avaliar a expressão dessa proteína in vitro e ex vivo. A transfecção foi realizada por eletroporação e contato. Ambas as estratégias se mostraram eficientes. Nossos resultados mostram que os linfócitos B foram capazes de expressar a GFP por quinze dias, após a transferência adotiva para animais deficientes em linfócitos B. Além disso, os linfócitos B transfectados com plasmidio que codifica a IL-12 foram capazes de expressar a proteína in vitro e secretá-la. Para avaliar se o processo de transfecção poderia interferir com o fenótipo do linfócito B 
avaliou-se a expressão de algumas moléculas de ativação nos linfócitos B transfectados. Não houve alteração da expressão de CD40, CD80, CD86 e MHC de classe II após transferência adotiva dos linfócitos no período avaliado de 15 dias. Além disso, a produção de IgG não foi alterada. No entanto, houve uma redução da produção de IgM, sugerindo que essa alteração possa ser decorrente da ação da IL-12 na troca de isotipos de imunoglobulinas. A eficiência dos linfócitos B transfectadas em terapia gênica foi avaliada usando modelo de melanoma B16F10 em animais deficientes de IL-12 (IL-12 KO). Os animais IL-KO que receberam transferência adotiva de 1 x $10^{6}$ linfócitos B transfectadas com plasmídeo da IL-12, mostraram redução do peso tumo- ral e uma maior sobrevida, quando comparados aos controles. A análise histológica mostrou que esses animais apresentavam também uma redução da área tumoral sugerindo um maior numero de células apoptóticas. Além disso, o perfil de células infiltrantes no tumor mostrou um aumento no número de linfócitos T CD4 e CD8 e NK, apenas nos animais que receberam a transferência adotiva. Em conjunto esses dados mostram que a transferência de linfócitos $\mathrm{B}$ expressando IL-12 foi funcional e capaz de conter o desenvolvimento tumoral. Esses resultados abrem perspectivas para o uso de linfócitos $\mathrm{B}$ em terapia gênica, visando à transferência de proteínas e/ou sua atividade de apresentação de antígenos para o controle de doenças.

\section{O PAPEL DE GALECTINA-3 NA MIGRAÇÃO DE MONÓCITOS HUMANOS}

\section{Cláudia Danella Polli}

Orientadora: Profa. Dra. Gabriela Silva Bisson

Dissertação de Mestrado apresentada em 19/09/2008

Galectina-3, dentre outras atividades, comporta-se como uma molécula atraente para monócitos e macrófagos. Através de citometria de fluxo e microscopia confocal, observamos que hrGal-3 se liga à superfície de monócitos humanos, via CRD, uma vez que esta interação é inibível por lactose. Através da separação eletroforética de extratos protéicos das porções citoplasmática e de membrana de monócitos, seguida da eletrotransferência para membrana de nitrocelulose e sequiênciamento proteico das bandas obtidas, foram identificadas como moléculas ligantes de galectina-3: integrinas kIIb e $\beta 3$, áactinina-1 e vinculina.
Confirmamos alguns dados anteriores da literatura de que hrGal-3, é capaz de induzir migração de monócitos de maneira dose-dependente, proporcionando uma curva em forma de sino característica de outros atraentes. Com o intuito de melhor caracterizarmos os mecanismos envolvidos na migração de monócitos induzida por galectina-3, avaliamos também se hrGal-3 induz migração de monócitos por mecanismo haptotático. Nossos resultados demonstram que hrGal-3 induz migração de monócitos humanos por haptotaxia, mecanismo viabilizado pela interação da lectina com as glicoproteínas da matriz extracelular, laminina e fibronectina. Os domínios N- e C-terminal de galectina-3 estão envolvidos na interação da lectina com laminina, enquanto na interação com fibronectina está envolvido principalmente o domínio N-terminal.

\section{ESTUDO DO PAPEL DE GALECTINA-1 NA INFECÇÃO EXPERIMENTAL POR Toxoplasma gondii}

\section{Natalia Sakura Koyama}

Orientador: Prof. Dr. Marcelo Dias Baruffi

Tese de Doutorado apresentada em 19/09/2008

Toxoplasma gondii é um parasita intracelular adquirido por meio da ingestão de cistos teciduais ou presentes em alimentos contaminados com fezes de gatos. A infecção oral de camundongos C57BL/6 com cistos de $T$. gondii causa ileíte associada a uma resposta Th1 exacerbada. Galectina-1, uma proteína ligante de $\beta$-galactosídeos, apresenta papel imunomodulador em diversos modelos de doenças inflamatórias e auto-imunes. Entretanto, o papel de galectina-1 durante a infecção parasitária ainda não foi determinado. Portanto, o objetivo deste trabalho foi estu- dar o papel de galectina-1 na resistência do hospedeiro contra a infecção por $T$. gondii e na patogênese da ileíte induzida por este parasita. A primeira estratégia utilizada foi o tratamento de camundongos infectados por $T$. gondii com galectina-1. Para tal, camundongos C57BL/6 foram infectados com 100 cistos da cepa ME-49 pela via oral e tratados com PBS ou galectina-1 (50 $\mu \mathrm{g} / \mathrm{animal})$ nos dias 0, 2, 4, 6 e 8 após a infecção. A taxa de mortalidade e a perda de peso foram significantemente menores em camundongos tratados com galectina-1 em relação aos não tratados. Ainda, a carga parasitária no cérebro de camundongos tratados com galectina-1 também foi menor. No dia 7 após a infecção, a análise histopatológica do intestino delgado mostra que o tratamento de camundongos infectados por T. gondii com galectina-1 induziu uma redução significante 
na inflamação intestinal. Além disso, camundongos tratados com galectina-1 infectados apresentaram uma redução nos níveis no IFN- $\gamma$ e TNF- $\alpha$ no soro e aumento na expressão de IL-10 e TGF- $\beta$ no baço no $7^{\circ}$ dia após infecção em relação ao camundongo controle não tratado. Além disso, a infecção por T. gondii provocou uma diminuição da expressão da galectina-1 no intestino delgado dos animais. Esses resultados sugerem que o efeito protetor induzido por galectina-1 pode estar relacionado com a redução das citocinas inflamatórias IFN- $\gamma$ e TNF- $\alpha$ e aumento das citocinas reguladoras IL-10 e TGF- $\beta$. Outra estratégia para avaliar o papel de galectina-1 durante a infecção por $T$. gondii foi o uso de camundongos geneticamente deficientes de galectina-1 (Gal-1-/-). A ausência de galectina-1 endógena também protegeu os animais, pois camundongos Gal-1-/apresentaram maior taxa de sobrevivência em relação aos selvagens C57BL/6 (Gal-1+/+). Apesar de ambos os camun- dongos apresentarem patologia intestinal similar, os animais Gal-1/- infectados apresentaram maiores níveis de IL10 e menores de IFN- $\gamma$ no intestino delgado em relação aos selvagens. Comparado aos camundongos Gal-1+/+, os animais Gal-1/- infectados apresentam menor número de células dendríticas, T CD4 ativadas, NK e NKT no linfonodo mesentérico. Ainda, camundongos deficientes de galectina-1 também apresentaram níveis séricos de IFN- $\gamma$ e IL-12 menores em relação aos selvagens. Em conjunto, esses dados sugerem a função benéfica tanto da ausência de galectina-1 endógena como a administração de galectina-1 exógena na resistência a infecção por $T$. gondii pode estar associada à montagem de uma resposta inflamatória menos intensa em nível local e sistêmico. Portanto, este estudo abre novas perspectivas para a compreensão da função de galectina-1, endógena e exógena, na indução da homeostase imunológica frente a processos infecciosos.

\section{AVALIAÇÃO DA DETECÇÃO DA PROTEÍNA NS1 NO DIAGNÓSTICO DA INFECÇÃO PELO VÍ- RUS DENGUE-3 EM COMPARAÇÃO A OUTROS MÉTODOS LABORATORIAIS UTILIZADOS NO DIAGNÓSTICO DA DENGUE}

\section{Luiza Antunes de Castro}

Orientador: Prof. Dr. Benedito Antônio Lopes da Fonseca

Dissertação de Mestrado apresentada em 22/09/2008

As infecções causadas pelos vírus dengue representam a principal arbovirose em nível mundial e são da maior importância para o Brasil. A dengue apresenta uma ampla variedade de sintomas clínicos desde infecção assintomática até doença grave, a dengue hemorrágica ou síndrome do choque da dengue. O diagnóstico da dengue aplicado na rotina requer que seja feita uma coleta de sangue na fase de convalescença, porém a experiência mostra que muitos pacientes não retornam para fazer esta coleta. Por esta razão um bom método de diagnóstico na fase aguda da doença é fundamental para a adoção de condutas terapêuticas capazes de minimizar complicações e reduzir a mortalidade, além de ser muito importante para o manejo clínico e epidemiológico da dengue em áreas onde múltiplos Flavivirus são endêmicos, como é o caso do Brasil. Com o intuito de aperfeiçoar o diagnóstico da dengue, durante a fase aguda da doença, foi avaliada neste estudo a sensibilidade e especificidade da deteç̧ão da proteína NS 1 comparando com a detecção do vírus por RT -PC R, sorologia e isolamento viral em Ribeirão Preto. Foram avaliados 250 pacientes com suspeita clínica de dengue. Do total de pacientes estudados, em $81(32,4 \%)$ foi possível a detecção molecular do agente. No isolamento viral 34 amostras foram positivas por IFI e 51 foram positivas utilizando a PCR, como método de deteç̧ão do vírus dengue em sobrenadante do cultivo celular. A detecção de IgM ocor- reu em $26 \%$ das amostras analisadas. 36 amostras positivas para a RT -PCR foram IgM negativos por terem sido colhidas em média apenas 2,1 dias após o início dos sintomas, e 22 amostras foram positivas para IgM e negativas para o RT -PCR e isolamento viral. A detecção de IgG anti- dengue ocorreu em $103(41,2 \%)$ amostras. Destas 32 (31 \% -32/103) foram tanto IgM quanto IgG positivas, e das amostras que foram positivas somente para IgG, $12(16,90 \%$ - 12/71) foram positivas também para o PCR. A sensibilidade do teste de NS1 quando comparada à detecção de IgM anti-dengue ou resultado positivo de RT -PCR foi de $76,2 \%$ e a especificidade de $96,5 \%$ O valor preditivo positivo neste caso foi de $94,1 \%$, com um valor preditivo negativo de $84,8 \%$. Já quando foram consideradas apenas os resultados positivos para IgM e positivos para o RT -PCR a sensibilidade do teste subiu para $95,1 \%$ e a especificidade foi $77,9 \%$. O valor preditivo positivo foi de $45,9 \%$, com um valor preditivo negativo de $98,9 \%$. O teste de NS 1 apresentou melhores resultados que as técnicas de diagnóstico que podem ser usadas na fase aguda da doença (RT -PCR e isolamento viral), além de ter tido uma menor queda na positividade quando comparada ao aumento nos dias de sintomas em que a amostra foi coletada. Foi possível observar que o kit apresentou um bom desempenho, sendo capaz de detectar a infecção por mais tempo que o RT -PCR e logo no início dos sintomas. A técnica de detecção de NS1 viral representa uma importante ferramenta diagnóstica em infecções por dengue, principalmente em áreas muito endêmicas e onde a demanda é grande, possuindo uma alta especificidade e boa sensibilidade. 


\section{DANO DO DNA E SÍTIOS POLIMÓRFICOS DOS GENES RESPONSÁVEIS PELO REPARO DE DNA (XRCCI E XRCC4), EM PACIENTES COM ESCLEROSE SISTÊMICA}

Gustavo Martelli Palomino

Orientador: Prof. Dr. Eduardo Antonio Donadi

Dissertação de Mestrado apresentada em 29/09/2008

Pacientes com esclerose sistêmica (ES) apresentam aumento da toxicidade quando expostos a agentes genotóxicos e instabilidade genômica mesmo antes do desenvolvimento da doença (desde o aparecimento do fenômeno de Raynaud). Posto que não existem dados acerca do reparo do dano de DNA em pacientes com ES, neste estudo, avaliou-se o dano basal no DNA (ensaio do cometa) e os polimorfismos de genes envolvidos no reparo de DNA XRCCl (Arg/Gln) e XRCC4 (IIe/Thr). Foram avaliados 177 pacientes e 191 indivíduos saudáveis quanto às frequiências alélicas e genotípicas do polimorfismo de XRCC1 e XRCC4. Desses, 56 pacientes e 36 indivíduos saudáveis foram avaliados quanto ao dano basal no DNA (avaliado pelo tail moment TM). As análises estatísticas foram feitas utilizando-se o programa GraphPad Instat e o SigmaStat. Comparados aos controles (TM = 3,50), os pacientes com ES apresentaram dano basal no DNA significantemente mais elevado (TM= $28,30 ; \mathrm{p}<0,0011)$. Após estratificação dos pacientes de acordo com as variantes clínicas (formas limitada ou difusa), achados clínicos (acometimento de órgãos e tecidos) e ma- nifestações laboratoriais (auto-anticorpos), não observamos diferenças significantes. Comparando-se com os controles, a freqüência do alelo mutante XRCC1 Gln foi significativamente maior no grupo de pacientes com a forma limitada da doença e naqueles apresentando escore de Rodman > 12 ou manifestações cutâneas ( $\mathrm{p}<0,001$ para cada comparação). Ainda, a freqüência genotípica XRCC1 Gln/Gln também foi maior em pacientes com a forma limitada da doença $(\mathrm{p}=0,0147)$. As freqüências gênicas e genotípicas para o XRCC4 não apresentaram diferenças significantes entre pacientes e controles. O dano no DNA não foi influenciado pelo genótipo XRCC1 no grupo de pacientes; no entanto, para o loco XRCC4, os pacientes heterozigotos (IIe/Thr) apresentaram nível significativamente maior de dano basal no DNA (TM= 80,04) em relação ao genótipo homozigoto selvagem (IIe/Ile) $(\mathrm{p}<0,001)$. Já para o grupo controle, indivíduos heterozigotos para o polimorfismo tanto no gene XRCC1 (Arg/Gln) quanto no gene XRCC4 (IIe/Thr) apresentaram maior nível de dano no DNA $(\mathrm{TM}=11$ e 15, 52, respectivamente) do que os indivíduos com os outros genótipos $(\mathrm{p}<0,001)$. Nossos resultados confirmam a presença da instabilidade genômica em linfócitos de pacientes com ES, sendo o XRCC1 Gln e XRCC4 Thr associados a ineficiência do reparo ao dano de DNA.

\section{NEUROLOGIA}

\section{EFEITOS DO PRÉ-CONDICIONAMENTO HIPÓXICO NA EPILEPSIA NO MODELO DO STATUS EPILEPTICUS INDUZIDO POR LÍTIO-PILOCARPINA}

\section{Raquel Araujo Do Val Da Silva \\ Orientador: Prof. Dr. João Pereira Leite \\ Dissertação de Mestrado apresentada em 27/07/2008}

Introdução: A Epilepsia do Lobo Temporal (ELT) é a forma mais comum de epilepsia focal no adulto. A ELT envolve estruturas mesiotemporais e comumente associa-se a esclerose hipocampal, onde há perda neuronal variável e brotamento anormal das fibras musgosas (BFM) na camada molecular interna do giro denteado. Estímulos potencialmente deletérios às células podem, quando aplicados próximos ao limiar de lesão irreversível, ativar mecanismos protetores endógenos, diminuindo potencialmente o impacto de um estímulo subseqüente, mais intenso, sendo este fenômeno conhecido como tolerância ou pré-condicionamento. Existem indícios de que esta tolerância possa ocorrer frente a estímulos de natureza diversa, como a isquemia cerebral ou crises epilépticas. O pré-condicionamento induzido por hipóxia subletal pode conferir neuroproteção contra insultos secundários, como nas crises epilépticas (tolerância cruzada).

Objetivos: Neste trabalho, avaliamos o efeito do pré-condicionamento através da hipóxia moderada sobre o status epilepticus (SE) induzido por lítio-pilocarpina e nas crises espontâneas e recorrentes (CERs) subseqüentes, assim como na morte neuronal e na reorganização das fibras musgosas no hipocampo.

Métodos: Ratos Wistar machos foram submetidos a um pré-condicionamento de dois episódios de hipóxia (7\% $\mathrm{O} 2$, com 30 minutos de duração cada um e intervalo de 24 horas entre eles), 20 horas antes da injeção sistêmica de lítio-pilocarpina e da apresentação de SE durante 4 horas. 
Grupos controle foram submetidos a apenas SE, hipóxia ou salina. Grupos de animais foram sacrificados 1 dia, 7 dias e 2 meses após o fim do SE, e seus cérebros processados para histoquímicas de neo-Timm, Nissl e Fluoro-Jade B. No grupo de 2 meses foi registrada a ocorrência de CERs.

Resultados: $\mathrm{O}$ grupo submetido ao pré-condicionamento, quando comparado com o grupo submetido ao SE, apresentou: 1) Maior latência para o inicio do SE (MannWhitney test, $\mathrm{p}=0,002) ; 2$ ) número similar de animais com remissão espontânea do SE $(4,8 \%$ e 2,8\%, respectivamente; $\mathrm{X} 2$ test, $\mathrm{p}=0,9) ; 3$ ) tendência a menor severidade das crises do SE (Mann-Whitney test, p=0,09) 4) latência para início, severidade, duração e número de CERs similares (Mann Withney test, $\mathrm{p}>0,1)$; 5) maior número de animais com tendência a não apresentar CER (40\% e 12,5\%, respectivamente; teste exato de Fisher, $\mathrm{p}=0,61)$; 6) densidade neuronal maior no hilo, CA3c e CA3b quando sacrificado 1 dia após o SE (ANOVA, p $\pm 0,01$ ), similar quando sacrificado 7 dias após o SE (ANOVA, p > 0,05) e maior no hilo e CA3a (ANOVA, p<0,05) quando sacrificado 2 meses após o SE; e 7) degeneração celular hipocampal e intensidade do brotamento das fibras musgosas na camada molecular interna similares (ANOVA, p > 0,05). Conclusão: Nossos resultados sugerem que o pré-condicionamento hipóxico protege contra a perda neuronal associada ao SE nas regiões do hilo e CA3, mas não altera a reorganização das fibras musgosas na camada molecular interna do giro denteado. No grupo submetido ao pré-condicionamento houve maior latência para o início do SE, tendência a menor severidade do SE, menor porcentagem de animais entraram na fase crônica. Porém, o pré-condicionamento não alterou a latência, severidade, duração, número total e freqüência das CERs que ocorrem até 2 meses após o SE induzido por lítiopilocarpina.

\section{ANÁLISE CRÍTICA SOBRE O PAPEL DA AVALIAÇÃO NEUROPSICOLÓGICA DENTRO DO CONTEXTO DA AVALIAÇÃO PRÉ-CIRÚRGICA DE CRIANÇAS E ADOLESCENTES COM EPILEP- SIA E CRISES FÁRMACO-RESISTENTES}

\section{Cecilia Souza de Oliveira}

Orientador: Prof. Dr. Américo Ceiki Sakamoto

Dissertação de Mestrado apresentada em 30/07/2008

Os prejuízos nas funções cognitivas são freqüentes nas crianças e adolescentes com epilepsia. Do ponto de vista clínico e demográfico, uma série de variáveis pode contribuir para a ocorrência dessas disfunções cognitivas. No contexto de um centro de cirurgia de epilepsia a avaliação neuropsicológica pode contribuir para a avaliação pré operatória fornecendo informações a respeito das habilidades e dos déficits cognitivos do paciente além de contribuir para o estabelecimento de um prognóstico pós-cirúrgico. Após a cirurgia ela contribui para na análise das mudanças no desempenho cognitivo do paciente em relação a sua performance antes do procedimento cirúrgico.

Objetivo: Este estudo teve como objetivo avaliar os aspectos cognitivos através da avaliação neuropsicológica de um grupo de crianças e adolescentes com epilepsia farmacoresistentes.

Métodos: Foram analisados retrospectivamente os prontuários de 73 crianças e adolescentes com epilepsia que realizaram Avaliação Neuropsicológica entre o ano de 2002 e 2007. Foram considerados aspectos clínicos, demográficos, eletrográficos, de Ressonância Magnética, de SPECT e Neuropsicológicos. Os dados dos pacientes foram analisados de acordo com as normas previamente aprovadas pelo Comitê de Ética em Pesquisa do Hospital das Clínicas da Faculdade de Medicina de Ribeirão Preto.

Resultados: Os exames contidos na investigação pré-operatória que foram mais importantes para a definição do procedimento cirúrgico foi o EEG crítico e a RM. AAvaliação Neuropsicológica pré-operatória não influenciou significativamente na decisão cirúrgica inicial. Identificou-se que as crianças com epilepsia com deficiência cognitiva não devem ser excluídas do procedimento cirúrgico. Com relação aos fatores preditivos de melhora de crises no pósoperatório observou-se que o EEG crítico, a RM lobar, o NPS localizatório e o tipo de cirurgia foram as variáveis consideradas significativas. Os achados da investigação sobre o impacto das crises na cognição foram que os pacientes que tiveram melhora das crises após o procedimento.

\section{ANÁLISE MORFOLÓGICA E MORFOMÉTRICA DO NERVO FRÊNICO DE RATOS ESPONTANE- AMENTE HIPERTENSOS (SHR), COM DIABETE CRÔNICO, INDUZIDOS EXPERIMENTALMEN- TE COM STREPTOZOTOCINA (STZ)}

\section{Renata da Silva Ferreira}

Orientadora: Profa. Dra. Valéria Paula Sassoli Fazan

Dissertação de Mestrado apresentada em 13/08/2008
A hipertensão é duas vezes mais comum em diabéticos do que na população em geral, sendo que os diabéticos com hipertensão apresentam um risco muito maior de doença 
cardiovascular, quando comparados com diabéticos normotensos ou mesmo hipertensos não diabéticos. Embora a associação entre hipertensão e diabete seja comum na prática clínica, não se sabe, ao certo, qual a contribuição de cada uma dessas doenças no desenvolvimento de neuropatias em pacientes hipertensos diabéticos. Entretanto, não encontramos relatos na literatura sobre descrições morfológicas de nervos periféricos em modelos experimentais de hipertensão arterial e diabete, associados. Dessa forma, nossos objetivos foram investigar a presença de neuropatia periférica, através da análise morfológica e morfométrica do nervo frênico de ratos normotensos (WKY), espontaneamente hipertensos (SHR) e espontaneamente hipertensos com diabete crônico (SHR+STZ) induzido experimentalmente por estreptozotocina (STZ). Para tanto, os animais do grupo III, receberam uma injeção única de STZ endovenosa 12 semanas antes dos experimentos. Os animais do grupo I e do grupo II receberam uma injeção endovenosa de veículo, também 12 semanas antes do experimento. No dia do experimento, após a medida indireta da pressão arterial e freqüência cardíaca, os animais foram perfundidos com solução fixadora e os nervos frênicos direito e esquerdo foram retirados e preparados com técnicas histológicas convencionais para estudos em microscopia de luz. A morfometria dos fascículos e das fibras mielínicas foi realizada com o auxílio de um programa computacional. A análise estatística foi realizada de forma a comparar dados obtidos entre segmentos do mesmo lado e níveis iguais entre lados diferentes nos animais de mesmo grupo, bem como entre grupos. Diferenças foram consideradas significativas quando $p<0,05$. Nossos resultados mostraram que, os nervos frênicos de ratos WKY, SHR e SHR+STZ são simétricos tanto longitudinalmente quanto lateralmente. A comparação entre os grupos mostra que os animais dos grupos II e III apresentam redução do número e densidade de fibras mielínicas e núcleos de células de Schwann, bem como redução da porcentagem da área fascicular ocupada pelas fibras mielínicas e pelos vasos capilares endoneurais, quando comparados aos animais do grupo I. Houve uma tendência de aumento dos parâmetros morfométricos médios das fibras mielínicas e respectivos axônios nos nervos dos animais dos grupos I e II, sem diferenças entre eles. Os histogramas de distribuição das fibras mielínicas dos animais do grupo I mostraram formato bimodal, com picos em 2,5 $\mu \mathrm{m}$ e 7,5 $\mu \mathrm{m}$ de diâmetro. Nos animais dos grupos II e III, esses histogramas apresentaram-se desviados para a direita, com redução importante da freqüência das fibras mielínicas de pequeno calibre, sem diferença entre eles. Nossos resultados sugerem a presença de uma neuropatia de fibras finas nos animais hipertensos, que não foi agravada pelo diabete nesse modelo experimental.

\section{EFEITO DA QUELAÇÃO DE ZINCO NO DESENVOLVIMENTO DE CRISES EPILÉPTICAS LÍMBICAS NO MODELO DE ABRASAMENTO ELÉTRICO RÁPIDO DAAMÍGDALA}

\section{Maira Licia Foresti \\ Orientador: Prof. Dr. Norberto Garcia Cairasco \\ Tese de Doutorado apresentada em 29/08/2008}

Um dos modelos experimentais mais utilizados para o estudo da epilepsia é o abrasamento elétrico em ratos, o qual é caracterizado pelo desenvolvimento progressivo de crises comportamentais e eletrencefalográficas em resposta a estimulações elétricas repetitivas, inicialmente subconvulsivas do sistema límbico. No abrasamento convencional, os estímulos são realizados 1 ou 2 vezes por dia, levando aproximadamente 2 semanas para o desenvolvimento do abrasamento, entretanto, intervalos pequenos têm provado ser uma alternativa rápida e eficaz para o estudo das alterações envolvendo a circuitaria neural e suas conseqüências. As principais estruturas envolvidas no início e na propagação das crises epilépticas decorrentes do abrasamento da amígdala são estruturas ricas em zinco. O zinco é um íon muito encontrado nos terminais sinápticos glutamatérgicos, principalmente de estruturas córtico-límbicas. Entretanto a participação deste íon nas sinapses e no desenvolvimento de crises epilépticas é no mínimo conflitante. O principal objetivo deste trabalho foi verificar os efeitos da quelação de zinco no modelo de abrasamento elétrico rápido da amígdala (ARK), para tanto, foi inicialmente necessário caracterizar melhor este modelo. Dessa forma, ratos Wistar machos foram implantados com eletrodos na amígdala e no hipocampo e foram submetidos ao ARK. Grupos experimentais receberam injeção i.p. do quelante de zinco DEDTC (700 mg/kg) ou PBS e foram estimulados. Grupos controles receberam as injeções, porém não foram estimulados. Os estímulos foram realizados na amígdala basolateral (pulso de $1 \mathrm{~ms}, 60 \mathrm{~Hz}, 500 \mu \mathrm{A}$, duração de $10 \mathrm{~s}$, intervalos de $30 \mathrm{~min}$ ) em uma série de 10 estímulos por dia durante dois dias. No terceiro dia foi realizado um estímulo adicional. As injeções foram realizadas antes de cada série de estímulos. Durante todo o protocolo os animais foram monitorados com vídeo-EEG. Três horas após o último estímulo (24 horas após a última série de 10 estímulos), os ratos foram anestesiados profundamente e perfundidos para posteriores análises histoquímicas com o objetivo de verificar brotamento de fibras musgosas (neo-Timm), neurodegeneração (Fluoro-Jade B) e atividade neuronal (cFos). Um grupo adicional de animais submetido ao ARK foi reestimulado e perfundido um mês após o término do protocolo. Resultados de animais submetidos ao ARK também foram compa- 
rados com outro modelo de epilepsia, o Status Epilepticus (SE) induzido por estimulação elétrica da amígdala. O modelo de ARK demonstrou ser eficaz para o rápido desenvolvimento de crises epilépticas e mesmo após um mês sem estimulações houve permanência de seu efeito. O brotamento de fibras musgosas e a degeneração neuronal não são necessários para a ocorrência de crises repetitivas cada vez mais graves e não podem ser induzidos pelo ARK num período curto de tempo. O modelo de ARK é mais ameno que o SE por estimulação elétrica da amígdala, pois apesar de ambos apresentarem semelhanças nas crises comporta- mentais e nas oscilações sustentadas do EEG, no ARK as crises duram menos tempo e há menor atividade neuronal. O tratamento com quelante de zinco durante o ARK não interfere na progressão das crises comportamentais e nas características de atividade EEGráfica na amígdala e hipocampo, porém diminui o tempo das crises e a freqüência de spikes pós-ictais no hipocampo. Além disso, estruturas que normalmente são ativadas durante o abrasamento apresentam menor atividade na ausência de zinco. Esses dados sugerem que o zinco endógeno pode ter um papel facilitatório no desenvolvimento das crisesepilépticas.

\section{APNÉIA OBSTRUTIVA DO SONO NA FASE AGUDA DE HEMORRAGIA INTRACEREBRAL HIPERTENSIVA}

\section{Octavio Marques Pontes Neto}

Orientadora: Profa. Dra. Regina Maria França Fernandes

Tese de Doutorado apresentada em 01/09/2008

A hemorragia intracerebral (HIC) é o subtipo de acidente vascular cerebral (AVC) de pior prognóstico e sem tratamento específico de impacto até o momento. A Síndrome da Apnéia-Hipopnéia Obstrutiva do Sono é um fator de risco para hipertensão arterial e tem sido associada com morbidade cerebrovascular. Estudos indicam que episódios de apnéia obstrutiva do sono (AOS) são frequientes na fase aguda de AVC isquêmico e podem se relacionar a deterioração neurológica precoce e maior mortalidade. Entretanto, não se conhece a frequiência e gravidade dos episódios de apnéia obstrutiva do sono (AOS) na fase aguda de HIC nem tampouco sua associação com a apresentação e evolução destes pacientes. No presente estudo objetivamos determinar a frequiência relativa e a gravidade dos episódios de AO em pacientes na fase aguda de HIC, caracterizar sua relação com expansão do hematoma, edema perihematoma, deterioração neurológica precoce e verificar seu impacto na evolução clínica, em evolução em 1 e 3 meses. Avaliamos 132 pacientes consecutivos com hemorragia intracerebral espontâneos admitidos na Unidade de Emergência do Hospital das Clínicas de Ribeirão Preto USP em entre janeiro de 2006 e fevereiro de 2008. Ao final da análise dos critérios de exclusão (coma, intubação orotraqueal ou HIC de etiologia secundária), 32 pacientes com HIC hipertensivo com menos de 48 horas de evolução foram incluídos no estudo e submetidos a polissonografia na primeira noite após admissão. Déficits neurológicos foram acompanhados pela escala de AVC do NIH. A incapacidade funcional foi avaliada pela escala de Rankin e pelo índice de Barthel, 3 e 6 meses após o sangramento. O volume da hemorragia e do edema perihematoma foram quantificado na tomografia computadorizada (TC) de crâ- nio de admissão controle em 24 horas e em 4 a 5 dias após os sintomas. O índice de apnéia-hipopnéia (IAH), definido como alterado quando IAH $>10$ e gravemente alterado IAH $>30$, na PSG. Dos 32 pacientes incluídos, 23 eram homens $(71,9 \%)$. A idade média foi de $57 \pm 11,8$ anos. A hemorragia cerebral ocorreu em gânglios da base em 17 pacientes $(53,12 \%)$, tálamo em 13 (40,6\%), lobar em 2 (6,2\%). À admissão, NIHSS mediano foi 15 (IR: 10-20), GCS mediano de 14 (IR: 12-15) e volume médio do AVCH de 26,4 $\pm 22,4 \mathrm{ml}$. Ocorreu crescimento do hematoma em 7 (21,87\%). Latência entre o início dos sintomas e a TC inicial foi de 14,6 $\pm 11,8$ horas, TC controle precoce de 41,3 $\pm 20,6$ horas e TC controle tardia após 111,5 $\pm 39,7$ horas. Latência entre início dos sintomas e PSG foi de 20,2 $\pm 12,5$ horas. AVCH teve início durante o sono em $8(25 \%)$ pacientes. Foi constatado IAH > 10 em $20(62,5 \%)$ pacientes, o que se mostrou independentemente relacionado com história prévia de roncos habituais $(\mathrm{p}=0.2)$ mas não com outros fatores de risco cardiovascular, topografia e tamanho da hemorragia, piora neurológica ou evolução funcional. IAH se correlacionou com a presença de o edema relativo na TC de crânio da admissão $\left(\mathrm{r}^{\mathrm{S}}=0,40 ; \mathrm{P}=0,031\right)$, na $\mathrm{TC}$ controle precoce $\left(\mathrm{r}^{\mathrm{S}}=0,46 ; \mathrm{P}=0,011\right)$ e na TC $\operatorname{tardia}\left(\mathrm{r}^{\mathrm{S}}=0,59 ; \mathrm{P}=0,006\right)$. A desorganização do traçado etroencefalográfico de sono na polissonogafia realizada durante a fase aguda de HIC foi quantificada visualmente e se correlacionou com pior prognóstico dos pacientes $\mathrm{O}$ decúbito supino exclusivo ocorreu em $75 \%$ dos pacientes na fase aguda de HIC. O tempo em decúbito supino se associou com o NIHSS na admissão ( $\left.\mathrm{r}^{\mathrm{S}}=0,48 ; \mathrm{P}=0,005\right)$, escala de coma de Glasgow na admissão ( $\left.\mathrm{r}^{\mathrm{S}}=-0.46 ; \mathrm{P}=0,008\right)$; e com o escore $\mathrm{ICH}\left(\mathrm{r}^{\mathrm{S}}=0,44\right.$; $\mathrm{P}=0,12$ ) na admissão. Episódios de $\mathrm{AOS}$ são freqüentes em pacientes não submetidos a intubação orotraqueal durante a fase aguda de hemorragia intracerebral espontânea. Um índice de apnéia-hipopnéia gravemente alterado está correlacionado com o desenvolvimento de edema cerebral nas primeiras 48 horas. 


\section{VARIAÇÕES NO ENVELHECIMENTO COGNITIVO E CEREBRAL DE IDOSOS SAUDÁVEIS}

\author{
Maria Paula Foss \\ Orientador: Prof. Dr. José Geraldo Speciali \\ Tese de Doutorado apresentada em 19/09/2008
}

A expectativa de vida aumentou nos países em desenvolvimento, como o Brasil, até perto dos 70 anos. Torna-se patente, portanto, definir formas mais positivas de envelhecer, pois descobertas científicas recentes não o associam somente a danos cerebrais e declínio cognitivo. Diante disso, surge nova definição que o caracteriza como fenômeno complexo de reorganização, otimização e plasticidade funcional podendo propiciar e manter a produtividade e uma vida feliz na velhice. O objetivo foi de avaliar a possível associação entre as variações no funcionamento cognitivo e nos marcadores biológicos da Ressonância Magnética (RMI), buscando o melhor entendimento das disfunções incluídas no conceito de envelhecimento normal. Casuística: foram avaliados 60 idosos com idade entre 58 e 83 anos (média 68,4; dp: 6,17), 43 mulheres e 17 homens e escolaridade de 1 a 15 anos (média: 7,1; dp: 4,39). Todos foram diagnosticados como saudáveis, por meio de exames clínico-laboratoriais, por um geriatra. Procedimento: avaliação inicial e assinatura do termo de consentimento livre e esclarecido. O médico geriatra selecionava aqueles que iriam realizar a avaliação neuropsicológica (ANP) e a RMI. A ANP iniciou-se com breve questionário sobre os dados de identificação, queixa neuropsicológica e a aplicação do instrumental de classificação socioeconômica ((NSE) Graciano, 1999). A seguir, eram aplicados, a escala de Mattis para avaliação de demência (MDRS) (Mattis, 1973 e 1988; Porto et al., 2003), teste de Stroop (Stroop, 1935 e Spreen e Strauss, 1998), fluência verbal (Spreen \& Benton, 1969, 1977), teste de Winconsin de classificação de cartas- WCST (Heaton et al., 1993), figura complexa de Rey (Rey 1941; Osterrieth, 1944; Rey, Franco, Oliveira, 1999), vocabulário - Wais - III (Wechsler, 1997; Nascimento, 2004), memória lógica - WMSR (Wechsler, 1987; Camargo et al., 1987), reprodução visual - WMS-R (Wechsler, 1987; Camargo et al., 1987), teste da aprendizagem auditivo-verbal de Rey (Rey, 1958, Spreen e Strauss, 1998 e Diniz et al., 2000). A RMI foi realizada num supercondutor de 1,5 Tesla, estimando-se as volumetrias (PSC\%, PSB\% e BPF\%), transferência de magnetização (MT $\mathrm{SC}$ e SB) e relaxometria em $\mathrm{T} 2$ (relaxo $\mathrm{SC}$ e SB). Os dados da avaliação neuropsicológica foram submetidos à análise multivariada de cluster pelo software SAS - Proc Cluster, utilizando-se o método hierárquico de ligação completa. Posteriormente, também, classificou-se os indivíduos com comprometimento cognitivo leve (CCL), segundo os critérios de Petersen (1999 e 2001). Realizou-se, também, análises exploratórias entre os dados demográficos distribuídos nos clusters pela ANOVA one-way ou o teste de X2 do
SPSS 13,0 for Windows. Os indicadores da RMI foram avaliados pela análise de cluster, usando o classificador kmeans do software Minitab e a comparação entre a RMI e o neuropsicológico foi realizada pelo teste de Mann-Whitney U do software SPSS 13.0 for Windows. As análises entre o neuropsicológico e a RMI foram feitas pela correlação de Spearman do pacote estatístico SPSS 13.0 for Windows e o Ancova (Montygomey, 2001) cujas covariáveis foram a idade e escolaridade de acordo com software SAS versão 9.1. Por último a análise multivariada de cluster foi realizada sem a inclusão da idade e os clusters sem a idade foram comparados com a RMI por meio da análise de variância não-paramétrica Kruskal- Wallis do software SPSS 13.0 for Windows. O nível de significância estatística adotado foi um $p<0,05$. Os resultados da avaliação neuropsicológica determinaram 4 clusters de indivíduos que foram classificados segundo Baltes e Baltes (1990): com "sucesso no envelhecimento cognitivo"(C1), com "envelhecimento com risco de desenvolver patologias futuras"(C2) e os outros dois com "envelhecimento dentro da média" (C3 e C4). Houve maior número com diagnóstico de CCL no C2 (85\%), seguido pelo C3 (11\%) e C4 (5,5\%). O C3 e o C4 apresentaram uma maior proporção de mulheres do que homens, enquanto que o NSE foi maior no $\mathrm{C} 1 \mathrm{e} \mathrm{C} 4$, ambos com escolaridades mais altas e com melhores desempenhos no vocabulário (WAIS III). Os participantes segundo os dados da RMI, por sua vez, foram subdivididos em dois grupos: um com melhores indicadores (CRMI 1) e outro com piores (CRMI 2). Esses grupos foram comparados, segundo os desempenhos neuropsicológicos, encontrando-se diferenças significativas quanto à idade e ao índice de interferência do teste de Stroop, sendo que o CRMI, com idosos mais novos, obteve melhores pontuações nesse índice. Houve, também, um maior número de correlações entre o teste de Stroop e outros que avaliavam a atenção e o funcionamento executivo, com os indicadores da RMI, principalmente, entre as taxas de transferência de magnetização e os tempos de relaxação. A relaxometria de SC foi a única que diferenciou os desempenhos no exame neuropsicológico, sendo que o $\mathrm{C} 2>\mathrm{C} 4>\mathrm{C} 1>\mathrm{C} 3$. Deve-se ressaltar, ainda, que houve influência da idade nas variáveis $\mathrm{PSC} \%, \mathrm{PSB} \%$, relaxo SC, MT SC, relaxo SB e MT SB, enquanto que a escolaridade influenciou somente a PSC\% e a relaxometria de SC. Diante da importante influência exercida pela idade sobre esses marcadores biológicos, optou-se por avaliar a possível formação de cluster sem essa variável, encontrando-se 4 clusters que diferiram, agora, segundo a escolaridade, sendo o $\mathrm{C} 1$ ( 12 anos) > C2 (3,6 anos) C3 (5 anos) e C4 (3,5 anos). Observou-se que a escolaridade foi determinante na formação desses clusters de acordo com a avaliação neuropsicológica. Demonstrou-se, então, diferença significativa entre os clusters na taxa de transferência de magnetização 
de substância branca (MTSB) de modo que o cluster 1, com maior escolaridade, obteve as melhores taxas do que os demais. Houve diferenças significativas no processo de envelhecimento cognitivo e cerebral nesse grupo de idosos saudáveis estimado pelos instrumentos de avaliação neuropsicológica e marcadores da RMI. As variáveis da ANP e as da RMI correlacionaram-se, principalmente, entre a atenção e funções executivas com as taxas de transferência de magnetização e o tempo de relaxação. Em relação ao neuropsicológico verificou-se que o teste de Stroop dife- renciou os idosos mais velhos e com piores marcadores na RMI. Por outro lado, existiu diferença na relaxometria de substância cinzenta (Relaxo SC) em relação aos desempenhos apresentados nos testes neuropsicológicos, sendo que os grupos com risco de desenvolver anormalidades futuras obtiveram maiores tempos de relaxação de SC do que os demais. A MT SB, por sua vez, também diferenciou os grupos com melhor desempenho neuropsicológico e maior escolaridade, apresentando maior preservação dessas fibras neurais.

\section{OFTALMOLOGIA, OTORRINOLARINGOLOGIA E CIRURGIA DE CABEÇA E PESCOÇO}

\section{O DESENVOLVIMENTO LINGÜÍSTICO DE UM SUJEITO COM SURDEZ CONGÊNITA PRO- FUNDA: A TRAJETÓRIA PARA A CONQUISTA DE SUA IDENTIDADE COMO PESSOA SURDA}

\section{Regina Lúcia Teixeira Sampaio \\ Orientadora: Profa. Dra. Myriam de Lima Isaac \\ Dissertação de Mestrado apresentada em 07/07/2008}

O presente estudo teve como proposta analisar o desenvolvimento da linguagem de um sujeito com surdez congênita profunda, tentando esclarecer quais foram os elementos significativos que propiciaram sua progressão ao longo do tempo, e, ao mesmo tempo, buscar compreender como foi o processo em que o mesmo conquistou sua identidade como pessoa surda. Para tanto, este estudo analisou de forma longitudinal, sob a ótica do atendimento fonoaudiológico, a trajetória deste sujeito durante o período que engloba a faixa etária de 12 meses a 19 anos, e em um corte transversal, por meio de uma entrevista não-direcionada em sua idade atual, aos 26 anos. Para o estudo longitudinal foram coletados dados, por meio do levantamento do prontuário de atendimento fonoaudiológico, sendo avaliadas, nos diferentes materiais, as informações que esclareceram seu processo de desenvolvimento da linguagem. A análise longitudinal foi dividida de acordo com três fases, em que ocorreram mudanças na abordagem metodológica: fase 1, abordagem Oralista, de 12 meses a 2 anos e 9 meses; fase 2, Comunicação Total, de 2 anos e 10 meses a 10 anos e 9 meses; fase 3 , a partir dos 10 anos e 10 meses de idade, Comunicação Total rumo ao Bilingüismo. No corte transversal deste estudo foi realizada uma entrevista nãodirecionada, em que o sujeito fez uma narrativa escrita espontânea de sua história de vida. A partir dessas análises foi possível compreender que os gestos e os sinais foram importantes para facilitar a comunicação e para o desenvolvimento da linguagem e da alta na modalidade oral-gestual; que estas aquisições, por sua vez, foram a base para a aprendizagem inicial da linguagem escrita; no entanto, posteriormente, foi a escrita que, sendo estimulada com os sinais da língua de sinais e outros recursos visuais, possibilitou a apropriação (estruturação) da língua, o avanço da linguagem e a melhora da oralidade. Contudo, todo o seu desenvolvimento não foi suficiente para garantir sua integração social com ouvintes, e foi somente depois de sua aproximação com outros surdos e de aprender a língua de sinais, que o sujeito pode conquistar sua identidade como pessoa não ouvinte, e passou a adotar uma atitude positiva frente à sua condição de ser surdo. A partir de então, pôde fazer escolhas mais definidas para a sua vida, de cunho afetivo, profissional e social, e de expandir suas relações para a convivência com ouvintes e surdos em diferentes situações, de acordo com a sua própria opção. Este estudo mostrou que, no atendimento fonoaudiológico do sujeito surdo, não deve ser considerado de forma restrita o enfoque clínico terapêutico, mas sim, que os profissionais envolvidos nesse processo, devem ter olhares diferentes considerando o campo sócio-antropológico e as diferenças lingüísticas e culturais. Dessa forma, a pessoa sura não pode ser vista como um ser com uma alteração biológica, que deva ser reparada, mas sim como um indivíduo que tem diferenças lingüísticas, educacionais, culturais, sociais e afetivas, e que, se respeitada sua alteridade e oferecidas oportunidades adequadas às suas necessidades, tem condições de desenvolver suas potencialidades. 


\section{ACHADOS AUDIOLÓGICOS EM PORTADORES DE DIABETES MELLITUS INSULINO-DEPEN- DENTES.}

Gisele Passos Doricci

Orientadora: Profa. Dra. Myriam de Lima Isaac

Dissertação de Mestrado apresentada em 15/07/2008

O diabetes mellitus (DM) é uma das doenças crônico degenerativas mais prevalentes nos dias de hoje. Tivemos com objetivo caracterizar os aspectos clínicos e audiológicos apresentados pelos sujeitos do estudo e avaliar a função auditiva de pacientes com tal alteração metabólica. Foram avaliados 24 indivíduos com diabetes mellitus tipo I e 24 indivíduos do grupo controle, com idade entre 18 e 35 anos $(X=28,08)$ em ambos os grupos. .Realizamos os testes: Audiometria tonal liminar, Imitanciometria e Potencial Evocado Auditivo de Tronco Encefálico (PEATE).

Observamos por meio de análise do prontuário mé- dico, que muitos indivíduos apresentavam complicações como neuropatia, retinopatia, nefropatia, alterações cardiovasculares devido ao DM. As queixas otoneurológicas mais prevalentes foram tontura $(17 \%)$ e zumbido $(21 \%)$. No PEATE, não foram observadas alterações auditivas em pacientes, com diabetes mellitus insulino-dependentes. Apesar de não terem apresentado perda auditiva, observamos que a média dos limiares auditivos tonais no grupo de indivíduos com DM foi maior que, a média dos limiares do grupo controle em todas as frequiências, em ambas as orelhas. Verificamos ainda, um aumento no limiar do reflexo acústico do músculo do estapédio contralateral. Outros estudos devem ser realizados a fim de elucidar se o paciente jovem apresenta alterações auditivas periférica e/ou central, objetivando um diagnóstico e intervenção precoces.

\section{RELAÇÃO ENTRE O ACOMETIMENTO DA MUSCULATURA OCULOROTATÓRIA E DOS MÚS- CULOS LEVANTADOR DA PÁLPEBRA SUPERIOR, OCCIPITOFRONTAL E ORBICULAR OCU- LAR EM DIFERENTES TIPOS DE MIOPATIA}

\section{Flávia Augusta Attié de Castro}

Orientador: Prof. Dr. Antonio Augusto Velasco e Cruz

Tese de Doutorado apresentada em 22/07/2008

O oftalmologista e, principalmente, o especialista em oculoplástica e estrabismo, se depara muitas vezes com a difícil questão da ptose miogênica e deficiência oculomotora em pacientes com miopatia. O comportamento da musculatura oculorrotatória, do occipitofrontal, do levantador da pálpebra superior e do orbicular periocular é virtualmente desconhecido em miopatias. O objetivo da presente pesquisa foi descrever o comportamento desses grupos musculares em miopatias específicas. Foi realizado estudo observacional de 27 sujeitos sem miopatia (grupo controle), 19 pacientes com mitocondriopatia e oftalmoplegia externa crônica progressiva, 21 pacientes com distrofia facioescapuloumeral, 36 com distrofia miotônica e 29 com disfunção mitocondrial sem oftalmoplegia. Fotografias e processamento computadorizado de imagem foram utilizados para a medida da amplitude das versões oculares, excursão palpebral e elevação do supercílio. Blefaroptose foi um achado frequiente nos pacientes com distrofia miotônica e mitocondriopatia associada à oftalmoplegia evidente. Houve diferença no acometimento da musculatura estudada entre os grupos. A musculatura oculorrotatória, o frontal, o levantador e o orbicular se mostraram amplamente alterados nos pacientes com distrofia miotônica e mitocondriopatia com oftalmoplegia externa crônica progressiva. Os grupos de distrofia facioescapuloumeral e disfunção mitocondrial sem oftalmoplegia não apresentaram alterações significativas na motilidade ocular, função frontal e função do levantador da pálpebra superior. Houve correlação linear entre a função do levantador e o posicionamento palpebral. Estudos prospectivos poderão adicionar informações importantes ao entendimento do acometimento da musculatura periocular nas miopatias. Os resultados obtidos permitem inferir que a suspensão frontal conservadora poderia beneficiar os pacientes com ptose miopática, melhorando sua qualidade de vida, mesmo no grupo com oftalmoplegia externa crônica progressiva.

\section{DESENVOLVIMENTO DE UM EQUIPAMENTO PARA AVALIAÇÃO DOS POTENCIAIS MIOGÊNICOS EVOCADOS VESTIBULARES DE AMPLO CONTROLE DOS PARÂMETROS}

Aline Cabral de Oliveira

Orientador: Prof. Dr. José Fernando Colafêmina

Dissertação de Mestrado apresentada em 08/08/2008
Os potenciais miogênicos evocados vestibulares são reflexos vestíbulo-espinhais; de média latência; decorrentes da estimulação acústica da mácula sacular; com estímu- 
los de alta intensidade. A atividade elétrica dos músculos do pescoço; em especial do músculo esternocleidomastoideo; é captada com o auxílio de eletrodos de superfície. Esse potencial verifica se o órgão vestibular é sensível ao som e se existem alterações na mácula sacular; no nervo vestibular inferior; nas vias eferentes descendentes ou mesmo nas terminações nervosas nos músculos. Atualmente; ainda não existe um instrumento específico para a avaliação dos potencias miogênicos evocados vestibulares; sendo a mesma realizada por meio de um equipamento desenvolvido para a captação de potenciais evocados auditivos; já disponível no mercado. Assim; as funções de amplificação; filtragem; estimulação; janela de captação; rejeição de artefatos e características de promediação; bem como o próprio software de gerenciamento; ficam muito a desejar para a nova função que lhe é atribuída. O presente trabalho; então; teve como objetivo desenvolver e testar um equipamento eficiente para a avaliação dos potenciais miogênicos evocados vestibulares; de amplo controle dos parâmetros do exame pelo pesquisador. Dessa maneira; foi elaborado um equipamento específico; capaz de gerar estímulos e registrar os reflexos vestíbulo-espinhais. Após a realização de testes preliminares e da caracterização do dispositivo; foi realizado teste-piloto com onze ouvintes normais; sendo seis mulheres e cinco homens. A partir de estímulos sonoros tone bursts de $10 \mathrm{~ms}$ (subida: $4 \mathrm{~ms}$; platô: $2 \mathrm{~ms}$; descida: $4 \mathrm{~ms}$ ); frequiência de $500 \mathrm{~Hz}$; apresentados na taxa de $5 \mathrm{~Hz}$; com intensidade de $90 \mathrm{dBNAn}$; foram registrados os poten- ciais miogênicos evocados com janelas de $80 \mathrm{~ms}$. O exame era finalizado após promediação de 200 estímulos. Esse teste foi conduzido com o equipamento desenvolvido e com outro considerado padrão-ouro. As respostas foram analisadas por meio da morfologia; demarcando-se as ondas n 13 e p23 pelas latências dos primeiros picos negativo e positivo. Em seguida; foi obtido o índice de assimetria e os resultados comparados entre os dois aparelhos. Aplicando-se o teste de Wilcoxon; pode-se constatar ausência de diferenças estatisticamente significativas; quando comparadas as respostas dos dois instrumentos; quanto aos parâmetros de latência e amplitude dos componentes n13 e p23; exceto para a latência de $\mathrm{p} 23$; com valor de $\mathrm{p}=0 ; 005$. Pode-se observar maiores valores de assimetria para o aparelho EP25 que para o novo instrumento; no que se refere a componente n13. Quanto a componente p23; esses índices foram maiores na evocação pelo novo equipamento; entretanto o teste Qui-quadrado revelou que não existem diferenças estatisticamente significativas (valores de $p=0 ; 14$ e $0 ; 60$ ) para as amplitudes de $\mathrm{n} 13$ e p23; respectivamente. $\mathrm{O}$ valor do índice de assimetria inter-pico n13-p23; para o novo aparelho $(2 ; 10 \%)$; foi significativamente menor que o encontrado para o EP25 (30;55\%); com p menor que 0;01. Dessa forma; conclui-se que não existem diferenças para as latências e amplitudes do VEMP entre o EP25 e o novo dispositivo desenvolvido; apresentando; esse último; maior proximidade com os valores descritos na literatura e menor índice de assimetria da amplitude interpico n13-p23.

\section{ALTERAÇÕES DA MARGEM PALPEBRAL E DA SUPERFÍCIE OCULAR NO TRACOMA CICATRICIAL EM POPULAÇÃO ADULTA DE UMA ANTIGA ÁREA ENDÊMICA DO CARIRI CEARENSE}

\section{Abrahão da Rocha Lucena \\ Orientador: Prof. Dr. Antonio A. Velasco e Cruz \\ Tese de Doutorado apresentada em 12/09/2008}

Objetivos: Determinar a prevalência das formas clínicas de tracoma através de um corte transversal, avaliando fatores epidemiológicos associados. Relacionar a presença de TS com a acuidade visual e função visual. Comparar o diagnóstico de lupa versus biomicroscópico. Comparar a posição da transição cutâneo-mucosa (TCM) da margem palpebral superior e limbo entre o grupo de indivíduos normais e com o TS. Verificar associação entre olho seco e TS através da verde lissamina, fluoresceína e questionário de perguntas.

Métodos: Foram examinados 412 indivíduos (178 homens e 234 mulheres), correspondendo a $67,2 \%$ da população do povoado. Os moradores eram sobre condições de moradia, escolaridade, higiene e renda. Em seguida, os moradores acima de 40 anos foram interrogados sobre a função visual. Após o exame no domicílio, os indivíduos com as formas cicatriciais de tracoma e um grupo de normais foram encaminhados para o posto de saúde, comparecendo 148 indivíduos (65 normais e 83 tracomatosos, 296 olhos. Foi realizada a medida da acuidade visual (AV) com correção através da tabela Log MAR e exame com lâmpada de fenda para: nova classificação do tracoma, avaliação da superfície ocular com verde lissamina e fluoresceína e exame do limbo e margem palpebral.

Resultados: Dos 412 indivíduos examinados, 304 $(73,7 \%)$ eram normais e $108(26,2 \%)$ tracomatosos. O TS foi a forma prevalente com 78 casos, seguida do TF com cinco, TT com três e $\mathrm{CO}$ com apenas dois casos. Com relação aos fatores sócio-econômicos referentes ao indivíduo observou-se diferenças significativas quanto a escolaridade $(\mathrm{p}=0,01)$, presente mais nos normais e quanto a renda $(\mathrm{p}=0,001)$ que foi maior nos tracomatosos. Quanto aos fatores referentes à moradia, observou-se diferenças quanto a presença de banheiro $(\mathrm{p}=0,013)$ e fossa $(\mathrm{p}=0,005)$, mais 
presentes nos grupo dos normais. Não foi percebida diferenças quanto a percepção visual entre os dois grupos, mas notou-se diferença quanto a AV ( $\mathrm{p}<0,001)$. O diagnóstico biomicroscópico concordou com o diagnóstico de lupa $(\mathrm{p}=1,00)$. Na pesquisa de olho seco foi percebida diferenças ( $\mathrm{p}<0,0001)$ nos homens no teste de verde lissamina que corou mais o grupo do TS. No questionário de sintomas, percebeu-se maiores queixas leves de olho seco no grupo das mulheres normais. No limbo, os olhos com TS apresentaram mais alterações $(\mathrm{p}=0,00)$, assim como na margem palpebral $(\mathrm{p}=0,00)$ quanto à localização anteriorizada da TCM.

Conclusões: A prevalência de tracoma foi alta principalmente pela forma TS $(90,7 \%)$. A pequena quantidade de TF inviabilizou o ciclo transmissão da Clamídia, tornan- do irrelevantes fatores de riscos classicamente conhecidos como relacionados ao tracoma. A função visual do grupo de indivíduos com TS não apresentou diferença em relação aos normais na faixa etária acima de 40 anos. A acuidade visual dos indivíduos com TS diferiu dos normais por apresentar maior quantidade de catarata. O diagnóstico de tracoma com lupa no campo foi concordante com o biomicroscópico efetuado no consultório. Houve associação entre olho seco e TS, verificado no teste com verde lissamina nos homens. Os sintomas leves de olho seco aconteceram de maneira diferente para mulheres, sendo mais freqüentes no grupo das normais. As alterações limbares (fossetas e pannus) e a posição anteriorizada da TCM da margem palpebral superior estão significativamente associadas ao TS.

\section{CONDIÇÕES MORFOFUNCIONAIS DE CRIANÇAS COM MORDIDA ABERTA ANTERIOR DENTOALVEOLAR E ESQUELÉTICA}

\section{Tatiana dos Santos Ciccone de Faria}

Orientadora: Profa.Dra. Cláudia Maria de Felício

Dissertação de Mestrado apresentada em 17/09/2008

A presente pesquisa teve como objetivo comparar crianças com mordida aberta anterior dentoalveolar, mordida aberta esquelética e oclusão normal quanto à atividade eletromiográfica e à largura e espessura dos músculos masseteres e temporais. Participaram 45 crianças, de ambos os gêneros, de 6 a 9 anos de idade, distribuídas em três grupos: oclusão normal (GC); portadoras de mordida aberta anterior dentoalveolar (MAAD) e de mordida aberta anterior esquelética (MAAE), definidos a partir do exame clínico odontológico e cefalométrico. Todos os sujeitos foram radiografados em norma lateral, com os dentes em oclusão habitual. As radiografias cefalométricas foram traçadas e medidas com a finalidade de classificar as má oclusões, a partir de 3 medidas angulares e 6 medidas lineares. A atividade eletromiográfica (EMG) dos músculos masseteres e temporais anteriores foi analisada nas condições de apertamento em máxima intercuspidação habitual dos dentes e máximo apertamento com rolete de algodão entre os dentes; mastigação livre de chiclete, amendoim, biscoito, barra de cereais e chocolate. A largura e a espessura, em cm, dos músculos masseteres e temporais foi mensurada por ultrassonografia
(US) no repouso e na máxima intercuspidação habitual. Para análise dos dados foram utilizados o Teste de Correlação de Pearson, análise de variância (ANOVA) e pós-teste de Tukey. De acordo com os resultados, não houve correlação entre as medidas cefalométricas e atividade EMG dos músculos temporal e masseter. Houve correlações positivas e significantes entre medidas de espessura e largura dos músculos e as medidas cefalométricas lineares de altura facial posterior, altura facial póstero-inferior, índice altura facial posterior e altura facial anterior, índice altura facial póstero-inferior e altura facial ântero-inferior e entre medidas US e EMG. Foram negativas e significantes as correlações entre medidas de espessura e largura dos músculos e direção de crescimento mandibular e a inclinação do plano mandibular. Houve diferença significante na atividade EMG entre os grupos GC e MAAE. Relativo à espessura e largura dos músculos investigados, houve diferenças significantes entre o GC e ambos os grupos com mordida aberta. Apesar das diferenças nas medidas cefalométricas relacionadas ao crescimento vertical, os grupos com mordida aberta dentoalveolar e esquelética não diferiram entre si quanto à atividade, espessura e largura dos músculos temporais e masseteres. O grupo controle apresentou maior atividade muscular que o MAAE e músculos mais espessos e mais largos que ambos os grupos com mordida aberta.

\section{MIOPIA COMO CAUSA DE DEFICIÊNCIA VISUAL EM SUJEITOS DE 10 A 15 ANOS NA CIDA- DE DE GURUPI-TO}

Fuad Moraes Ibrahim

Orientador: Prof. Dr. Jayter Silva de Paula

Dissertação de Mestrado apresentada em 19/09/2008
Objetivos: Avaliar a freqüência de miopia como causa de deficiência visual em sujeitos com idade entre 10 a 15 anos residentes na cidade de Gurupi assim como a sua rela- 
ção com a distribuição com idade e sexo.

Métodos: Estudo transversal populacional. Foram sorteados e avaliados 50 conglomerados dos 59 anteriormente utilizados pelo Instituto Brasileiro de Geografia e Estatística (IBGE) para a realização do Censo 2000 compreendendo toda a cidade de Gurupi. Uma equipe treinada visitou as casas seguindo uma ordem de quarteirões definidos previamente pelo IBGE. Foram usados como critérios de inclusão idade de 10 a 15 anos e residir no local por, pelo menos, seis meses. As residências em que não houve resposta foram revisitadas em uma segunda oportunidade. Após explicação do trabalho e o consentimento por escrito de um responsável, com a ajuda deste, foi preenchida uma ficha com os dados do sujeito. Foi avaliada a acuidade visual de cada olho sem correção, separadamente com cinco optotipos impressos de Snellen em linha correspondentes a visão 20/32 da tabela logMAR, a uma distância de 4 metros. Os sujeitos que apresentaram dificuldade de visualizar mais de um optotipo com um ou ambos os olhos foram encaminhados para avaliação em consultório por um oftalmologista. Foi realizado teste de motilidade ocular e revistada a acuidade visual com tabela de logMar retro iluminada a 4 metros. Após cicloplegia, foi feita a auto-refração, seguido da refração subjetiva utilizando tabela logMar, exame externo, biomicroscopia e fundoscopia. Foi prescrita a correção para os sujeitos que apresentaram melhora da acuidade visual após a refração. A deficiência foi classificada em refrativa, catarata, tracoma, ambliopia, alterações retinianas, estrabismo e outros.

Resultados: Foram examinados 1590 sujeitos com idade variando entre 10 a 15 anos, sendo 814 (51\%) do sexo masculino e 776 (49\%) do sexo feminino. Dos 167 que apresentaram limitações para identificar os optotipos de Snellen, $127(76 \%)$ compareceram para a avaliação em consultório, sendo que 61 (59\%) não necessitaram de correção. Das correções, 15 (22\%) foram corrigidos com lentes com EE positivo. As prescrições com EE negativo somaram 51 (77\%) com variação entre - 0,5 até $-7,00 \mathrm{DE}$, correspondendo a uma freqüência de miopia de 3,2\%. Destes, 23 (45\%) eram do sexo masculino e $28(55 \%)$ do sexo feminino. Dos sujeitos que necessitaram de óculos, nove (10\%) ainda não faziam uso prévio de correção. Os erros refrativos foram a principal causa de deficiência de visão, responsáveis por $53(80 \%)$ dos casos, sendo $45(90 \%)$ míopes e oito (10\%) hipermetropes. Em seguida, ambliopia com 8 (12\%) sujeitos, 4 (6\%) com alterações retinianas e $1(1 \%)$ com catarata congênita. As variáveis sexo, idade, região onde residia, uso prévio de óculos foram associadas com a miopia por regressão multivariada sem nenhuma relação significativa.

Conclusão: Os erros refrativos são a principal causa de baixa de visão na faixa de idade examinada, com destaque para a miopia, que apresentou uma frequiência de $3,2 \%$. Nenhum dos fatores estudados apresentou relação estatística com a presença de miopia.

\section{VARIAÇÕES NO POSICIONAMENTO DOS EIXOS VISUAIS EM PACIENTES SUBMETIDOS A CI- RURGIAS DE ESTRABISMO}

Graciela Scalco Brum

Orientador: Prof. Dr. Harley E. A. Bicas

Dissertação de Mestrado apresentada em 22/09/2008

Objetivos: determinar as variações no ângulo de posicionamento ocular pós-operatório em pacientes submetidos a cirurgias para correção de estrabismo e identificar possíveis fatores de risco associados a tal ocorrência.

Pacientes e métodos: foi realizado estudo retrospectivo de 819 pacientes portadores de estrabismo submetidos a cirurgia para correção do desvio ocular entre janeiro de 1995 e dezembro de 2005 no Hospital das Clínicas da Faculdade de Medicina de Ribeirão Preto da Universidade de São Paulo. Os pacientes foram divididos em quatro grupos (esotropia alternante, esotropia monocular, exotropia alternante e exotropia monocular) quanto ao tipo de desvio pré-operatorio e as variações no posicionamento ocular foram quantificadas em cada grupo. Foram testadas asso- ciações entre as variáveis estudadas.

Resultados: a prevalência de variações no posicionamento ocular (pós-operatório) maiores que 10" entre o total de pacientes estudado foi de 33,5\% (274 pacientes). Entre estes, foi verificada maior freqüência de desvios no sentido exotrópico (178 pacientes $(65,0 \%))$ do que no sentido esotrópico (96 pacientes $(35,0 \%)$ ), diferença esta que foi estatisticamente significativa (teste do qui-quadrado; $p<0,001)$. Nenhuma associação foi encontrada entre idade e sexo dos pacientes, estado sensorial e magnitude do desvio pré-operatório no desenvolvimento de variações no posicionamento ocular no pós-operatorio.

Conclusões: instabilidade no posicionamento ocular pode ocorrer ao longo do tempo em pacientes submetidos a cirurgias de estrabismo. Tal ocorrência reforça a necessidade do desenvolvimento de alternativas terapêuticas a fim de proporcionar maior estabilidade ao sistema oculomotor no pós-operatório de cirurgias de estrabismo. 


\section{ORTOPEDIA, TRAUMATOLOGIA E REABILITAÇÃO}

\section{ANÁLISE MORFOMÉTRICA DE MÚSCULOS SÓLEOS DE RATOS SUBMETIDOS A ALONGA- MENTO PASSIVO COM USO PRÉVIO DE ULTRA-SOM TERAPÊUTICO}

Gladson Ricardo Flor Bertolini

Orientador: Prof. Dr. Nilton Mazzer

Tese de Doutorado apresentada em 04/08/2008

O alongamento muscular é muito difundido entre atletas e pessoas envolvidas em atividades físicas, além de ser um procedimento rotineiro em clínicas de fisioterapia, principalmente visando o aumento na flexibilidade. O ultra-som terapêutico possui ações térmicas e não térmicas, gerando aumento de extensibilidade tecidual e metabolismo celular, e pode auxiliar nos efeitos anabólicos do alongamento estático. O objetivo deste estudo foi analisar as alterações morfométricas do tecido muscular, em sóleos de ratos, submetido a alongamento passivo estático de curta duração e poucas repetições, associado ao uso do ultra-som terapêutico. Foram utilizados 48 ratos Wistar, divididos em grupos tratados com doses térmicas $\left(0,5\right.$ e $\left.1,0 \mathrm{~W} / \mathrm{cm}^{2}\right)$ e não térmicas $\left(0,2, \mathrm{~W} / \mathrm{cm}^{2}\right)$, e subseqüente alongamento estático em 3 séries de $30 \mathrm{~s}$, além de grupos apenas tratados com ultrasom ou alongados, por 3 semanas, durante 15 dias de tratamento. Foram comparadas as variações encontradas entre o músculo sóleo esquerdo (MSE) e o MSD de cada grupo. As variáveis foram: peso e comprimento muscular, estimativa de sarcômeros em série na fibra e ao longo do músculo, comprimento de sarcômeros, diâmetro e área de fibras musculares. Os resultados apontaram alterações no comprimento muscular de repouso, para os grupos em que foi associado ultra-som terapêutico, em dose térmica, associadas ao alongamento estático, com aumento do mesmo. Além disso, para o grupo em que foi associado alongamento com ultrasom em $1 \mathrm{~W} / \mathrm{cm}^{2}$, os músculos apresentaram menor massa e área das fibras musculares, comparado com o lado contralateral. Para as outras variáveis analisadas não houve diferenças significativas. Conclui-se que o alongamento passivo estático e o uso isolado do ultra-som terapêutico, não produziram alterações morfométricas no sóleo de ratos, mas quando o alongamento foi associado ao ultra-som nas intensidades de 0,5 e $1,0 \mathrm{~W} / \mathrm{cm}^{2}$, houve aumento no comprimento muscular de repouso. A associação em $1,0 \mathrm{WI} \mathrm{cm}^{2}$ conduziu ainda a uma hipotrofia muscular. Para as outras variáveis analisadas e para a intensidade não térmica, do ultra-som terapêutico, não houve efeitos significativos.

\section{ESTUDO DO PROCESSO INFLAMATÓRIO INDUZIDO PELO NÚCLEO PULPOSO DO DISCO INTERVERTEBRAL COMO FATOR ETIOLÓGICO DA LOMBOCIATALGIA NA HÉRNIA DE DIS- CO LOMBAR}

\section{André Luis de Souza Grava \\ Orientador: Prof. Dr. Helton Luiz Aparecido Defino \\ Tese de Doutorado apresentada em 26/08/2008}

A hérnia de disco lombar é origem importante de dor crônica. Apesar de importantes pesquisas nas últimas décadas, o tratamento desta patologia ainda não apresenta resultados clínicos satisfatórios. Existem evidências de que a compressão mecânica do tecido nervoso provocada pela extrusão do disco intervertebral não é o único mecanismo envolvido na sintomatologia da hérnia de disco lombar e não explica totalmente as características do quadro clinico e a sua evolução para um estado crônico. Nos últimos anos cresce a hipótese da participação de um processo inflamatório no tecido nervoso local provocado pela presença do núcleo pulposo do disco intervertebral. Mediante esse cenário, desenvolvemos um modelo experimental em ratos que reproduz o quadro clínico da hérnia de disco lombar em humanos para estudar o papel dessa inflamação na gênese da dor. Foi coletado o núcleo pulposo autólogo (NP) de discos intervertebrais da base da cauda e implantados na coluna lombar, em diferentes níveis e em diferentes locais. Quando o NP foi sobreposto no gânglio da raiz dorsal (GRD) de L5, os ratos desenvolveram hiperalgesia em todos os testes mecânicos (Randall e Sellitto e von Frey eletrônico) e no teste térmico (Hargreaves). Foi também avaliada a influência da retirada cirúrgica do estímulo (NP) e constatou-se que, quando retirado precocemente o quadro hiperalgésico apresentava completa reversão, quando retirado na terceira semana mostrava resultados intermediários e numa fase tardia (após cinco semanas) permanecia irreversível. Nossos resultados também demonstraram a presença de concentrações significativas das citocinas pró-inflamatórias (TNF$\alpha$, IL-1 $\beta$, CINC-1) no NP, as quais parecem estar mediando o 
processo inflamatório induzido no GRD. A análise histopatológica dos GRDs em tempos diferentes, mostrou um processo degenerativo progressivo dos neurônios com importante proliferação de células da glia, e um aumento expressivo da sintase de óxido nítrico induzida (i-NOS), irreversível após a quinta semana. A participação das citocinas TNF- $\alpha$, IL-1 $\beta$ e CINC-1 foram verificadas pelo tratamento do NP coletado com anticorpos específicos anti-citocinas. $\mathrm{O}$ bloqueio da citocina TNF $\alpha$ demonstrou redução significativa da dor tanto na fase aguda, como na fase crônica. A inativação da IL-1 $\beta$ demonstrou redução significativa da dor aguda, mas não do quadro crônico. O bloqueio da CINC-1 não apresentou ação analgésica na fase aguda, mas mostrou-se eficiente na fase crônica. Finalmente realizamos o tratamento pós-operatório dos animais com diferentes classes de drogas analgésicas e antiinflamatórias. A morfina e a dexametasona apresentaram o maior efeito analgésico, a indometacina, foi capaz de inibir o quadro álgico agudo em cerca de $50 \%$, enquanto que o atenolol mostrou discreta redução da hiperalgesia aguda, mas foi eficaz no quadro crônico (após
14 dias). A associação da indometacina com atenolol induziu feito similar ao observado com administração da indometacina isoladamente na fase aguda e manteve-se eficiente na fase crônica. Esses dados sugerem que na fase aguda a participação das prostaglandinas é mais relevante, enquanto na fase crônica as aminas simpáticas têm participação mais proeminente. Concluindo, o modelo experimental inflamatório de hérnia de disco lombar em ratos mostrou-se confiável, reprodutível e de baixo custo. Ele permitiu o acompanhamento da hiperalgesia na fase pós-operatória aguda e crônica, possibilitando o estudo dos mecanismos inflamatórios envolvidos e o teste de novas terapias no tratamento desta patologia. Nossos resultados sugerem que a inflamação do gânglio da raiz dorsal induzida pelo núcleo pulposo do disco intervertebral apresenta papel importante na gênese da lombociatalgia e na sua evolução para dor crônica, esse processo é mediado pelas citocinas TNF- $\alpha$, IL-1 $\beta$, CINC-1; demonstram ainda que a evolução da hiperalgesia é proporcional ao tempo de contato do NP com o GRD e é sensível a diferentes tratamentos farmacológicos.

\section{ESTUDO DA REGENERAÇÃO ÓSSEA GUIADA COM ESPAÇADOR DE POLIMETILMETACRILA- TO E ANTIBIÓTICO EM FALHAS ÓSSEAS PREVIAMENTE INFECTADAS NO COELHO}

\section{Matheus Lemos Azi}

Orientador: Prof. Dr. Cleber Antonio Jansen Paccola

Tese de Doutorado apresentada em 17/09/2008

O tratamento da falha óssea diafisária associada à infecção é um dos mais importantes desafios terapêutico da atualidade. No intuído de avaliar os efeitos do uso de um espaçador de PMMA com gentamicina sobre a regeneração de falhas ósseas pelo periósteo, foi conduzido este estudo experimental, prospectivo e randomizado. O modelo utilizado para a realização do experimento foi a falha óssea de 15 mm na ulna de coelhos, sendo o estudo conduzido em duas etapas: na primeira foram utilizadas falhas sem infecção, e na segunda foi produzida a infecção utilizando um inoculo de $5 \times 10^{8} \mathrm{~S}$. aureus, visando avaliar a regeneração do defeito após a infecção. Foram formados 5 grupos levando-se em consideração a presença de infecção, o uso do espaçador de PMMA com antibiótico e a preservação do periósteo no defeito ósseo. Grupo 1, falha óssea tratada com espaçador de PMMA com antibiótico; grupo 2, falha óssea sem preenchimento; grupo 3, falha óssea infectada tratada com espaçador de PMMA com antibiótico; grupo 4, falha osteoperiosteal infectada tratada com espaçador de PMMA com antibiótico; grupo 5, falha óssea infectada sem preenchimento. As falhas ósseas sem infecção apresentaram regeneração significativamente maior do que as falhas ósseas infectadas. O uso do espaçador de polimetilmetacrilato com gentamicina produziu resultados melhores na regeneração óssea porem estes não foram significativos. Concluiu-se que uso do espaçador de PMMA como preenchedor temporário de falhas ósseas é um método efetivo de tratamento, e que alem de promover um controle efetivo do processo infeccioso, tem um impacto positivo sobre a regeneração espontânea de falhas ósseas pelo periósteo.

\section{EFEITO DA ESTIMULAÇÃO ELÉTRICA TRANSCUTÂNEA SOBRE A MANUTENÇÃO FUNCIONAL E ESTRUTURAL DO MÚSCULO ESQUELÉTICO DESNERVADO DE RATOS}

\section{Juliana de Tillio Polonio \\ Orientador: Prof. Dr. Nilton Mazzer \\ Dissertação de Mestrado apresentada em 18/09/2008}

A eletroestimulação para tratamento de músculos desnervados deve ser aplicada através do tratamento sele- tivo. Este estudo avaliou o efeito da eletroestimulação seletiva do músculo desnervado sobre sua estrutura e função. Foram utilizados cinqüenta ratos Wistar distribuídos em controle, desnervado estimulado e desnervado. Após avaliação eletrodiagnóstica de estímulo pré-desnervação, os animais sofreram desnervação proximal completa do 
músculo tibial anterior unilateral. Houve reavaliação semanal para adaptação dos parâmetros de tratamento seletivo, aplicado três vezes por semana. Os animais foram mortos após 7, 14, 28 e 56 dias do pós-cirúrgico. Foram realizados procedimentos histológicos, histoquímicos, estudos morfológicos e morfométricos. Os animais desnervado estimulados não apresentaram contratura da articulação do tornozelo e não houve autofagia nas patas. Alterações significa- tivas nas áreas das fibras musculares tipo IIB (desnervados estimulados aos 7 dias) e tipo IIA e híbridas (desnervados estimulados 28 e 56 dias) indicaram menor atrofia. Transição dos tipos de fibras musculares foi significativa, indicando uma manutenção do padrão funcional do músculo tibial anterior nos períodos de 7 e 14 dias. Conclui-se que houve manutenção temporária da estrutura e função do músculo tibial anterior desnervado através da eletroestimulação seletiva.

\section{PATOLOGIA}

\section{A EXPRESSÃO DIFERENCIAL DA TELOMERASE E DO FATOR DE CRESCIMENTO VASCULAR ENDOTELIAL PODE CONTRIBUIR PARA O COMPORTAMENTO MAIS AGRESSIVO DOS CAR- CINOMAS MAMÁRIOS p63}

\author{
Heveline Becker de Moura \\ Orientador: Prof. Dr. Alfredo Ribeiro-Silva \\ Dissertação de Mestrado apresentada em 04/07/2008
}

O p63, homólogo do p53, é marcador de células mioepiteliais nas glândulas mamárias normais e pode ser encontrada em cerca de $11 \%$ dos carcinomas mamários invasivos. O objetivo deste trabalho é estudar a relação entre a expressão da p63, fatores clínico-patológicos e marcadores utilizados em patologia mamária, incluindo reguladores do ciclo celular, oncogenes, proteínas relacionadas a apoptose, metaloproteinases e inibidores das metaloproteinases. Foi realizado estudo imuno-histoquímico com 27 anticorpos primários em 100 casos de carcinomas ductais invasores. Células p63 positivas foram encontradas em 16\% dos carcinomas. Os carcinomas p63-positivos são pouco diferenciados, negativos para receptores hormonais e apresentam índice de proliferação elevado. Estes carcinomas também apresentam correlação com estadiamento patológico avançado, tamanho tumoral e expressão de hTERT, TIMP1 e VEGF. A expressão de TIMP1 sugere que o estímulo antiproteolítico pode estar presente nos carcinomas p63 positivos. A atividade do hTERT está associada com metástase para linfonodos e proliferação celular. O VEGF regula a angiogênese que é um evento fundamental para o processo de crescimento tumoral e disseminação metastática. Portanto a expressão do hTERT e do VEGF nos carcinomas p63 positivos pode contribuir para o comportamento clínico mais agressivo destes carcinomas.

\section{INTERFERÊNCIA DA DEXAMETASONA NO CICLO PULMONAR DA INFECÇÃO POR Strongyloi- des Venezuelensis EM RATOS WISTAR}

\section{Cristiane Tefé-Silva}

Orientadora: Profa. Dra. Simone Gusmão Ramos

Dissertação de Mestrado apresentada em 07/08/2008

As estrongiloidíases são parasitoses intestinais causadas por várias espécies do gênero Strongyloides e apresentam distribuição cosmopolita. O objetivo deste estudo foi investigar a interferência do tratamento diário com dexametasona no ciclo pulmonar durante a infecção por Strongyloides venezuelensis em ratos. Investigamos o efeito do tratamento com glicocorticóides na migração de eosinófi- los, mastócitos e macrófagos no parênquima pulmonar. Demonstramos ainda, como os efeitos do tratamento diário com a dexametasona atuam na formação do granulomas. Quatro principais aspectos foram encontrados: 1) Redução de peso dos animais controles e tratados e infectados e tratados; 2) Aumento da inflamação hemorrágica, provocado pela passagem das larvas para o espaço alveolar; 3) Significante redução da migração de eosinófilos e mastócitos no eixo axial pulmonar e, 4) Interferência na migração de eosinófilos para os focos de passagem das larvas e, conseqüente, impedimento da organização do granuloma, suge- 
rindo que a formação da rede de fibras reticulares deve ter um papel crucial no aprisionamento do parasita, favorecendo um melhor desempenho das células inflamatórias na eliminação do mesmo. Este trabalho mostrou que o uso de drogas com ação imuno-modulatória, tais como a dexametasona, pode interferir na morbidade no ciclo pulmonar durante a infecção por $S$. venezuelensis, contribuindo para revelar os mecanismos envolvidos na sua patogênese.

\section{DETECÇÃO DO HPV E AVALIAÇÃO IMUNOISTOQUÍMICA DE PROTEÍNAS REGULADORAS DO CICLO CELULAR EM CARCINOMAS INVASIVOS DE LARINGE COM E SEM METÁSTASES}

\author{
Marcela Kazue Hassumi \\ Orientador: Prof. Dr. Edson Garcia Soares \\ Dissertação.Mestrado apresentada em 02/09/2008
}

O mecanismo de oncogênese na laringe pode ser controlado por vários fatores, entre eles fatores envolvidos na regulação do ciclo celular e outros de risco, tais como exposição prolongada ao fumo e álcool. O desenvolvimento do câncer de laringe também pode estar associado à infecção pelo HPV. Este estudo, análise imunoistoquímica quantitativa de p53, p27 e Mdm2, foi realizado em 54 pacientes com carcinoma invasivo de laringe subdivididos em: carcinoma com metástase (CLM), sem metástase (CLS) e linfonodos cervicais (LC). A detecção e tipificação do HPV foram realizadas pela reação em cadeia da polimerase (PCR) e os tipos de HPV avaliados foram HPV 6, 11, 16, 18, 31 e 33. Na análise quantitativa, alta expressão de p53, p27 e Mdm2 foi observada nos grupos CLM e CLS assim como nas biópsias dos linfonodos cervicais, indicando que a avaliação dessas proteínas poderia não discriminar carcinomas de laringe metastáticos e não-metastáticos. Detecção do HPV foi verificada em apenas 7,4\% dos casos. Dentre os pacientes HPV positivos, verificou-se expressão negativa de p53. Por outro lado, alta expressão de p27 e Mdm2 foi observada. Em conclusão, a avaliação quantitativa de p53, p27 e Mdm2 não permite traçar um perfil complementar em lesões metastáticas de laringe.

\section{PARTICIPAÇÃO DAS METALOPROTINASES 2 E 9 NO DESENVOLVIMENTO DE ANEURISMAS DA AORTA ABDOMINAL EM RATOS WISTAR}

\section{Karina Magalhães Alves da Mata}

Orientadora: Profa. Dra. Simone Gusmão Ramos

Dissertação de Mestrado apresentada em 04/09/2008

A degradação da matriz extracelular e de proteínas da parede aórtica associada à inflamação é uma das principais características dos aneurismas da aorta abdominal (AAA). O objetivo deste trabalho foi investigar a participação das metaloproteinases 2 e 9 na formação de AAAs, através de um modelo experimental inédito de indução de AAA em ratos Wistar, desencadeado por duas potenciais causas de secreção e ativação de MMP-2 e 9: alteração do fluxo sanguíneo e lesão vascular externa na aorta. A formação de aneurismas foi observada em 60\%-70\% dos animais, apresentando diâmetro de 7 a 8 vezes maior que o diâmetro normal da aorta. Histologicamente observou-se remodelamento, intensa resposta inflamatória, destruição maciça de fibras elásticas e aumento da síntese de colágeno na parede aórtica. A expressão de ambas as formas de MMP-2 foram observadas tanto nos AAAs como nos grupos controles, neste com menor atividade, entretanto a expressão da pró e da MMP-9 ativa foram encontradas apenas nos AAAs. Conclusão: Nossos resultados sugerem que tanto as MMP-2 quanto as MMP-9 apresentam importante papel no desenvolvimento de AAA e este novo modelo de indução de AAA, pode ajudar a elucidar os mecanismos que desencadeiam a secreção e ativação das MMP-2 e MMP-9 na formação de aneurismas.

\section{EFEITO DO ÉSTER FENETILA DO ÁCIDO CAFEICO NA LESÃO POR ISQUEMIA E REPERFUSÃO DO MÚSCULO ESQUELÉTICO EM RATOS}

\author{
Alessandra Regina Andrade-Silva \\ Orientador: Prof. Dr. Fernando Silva Ramalho \\ Tese de Doutorado apresentada em 25/09/2008
}

A isquemia do músculo esquelético, particularmente dos membros inferiores, é uma ocorrência e um problema clínico freqüente como consequiência de trauma por esma- 
gamento, hemorragia ou estenose vascular. Estudos experimentais e clínicos têm mostrado que a lesão induzida pela reperfusão, como resultado direto da restauração do fluxo sanguíneo ao tecido isquêmico, é ainda mais agressiva que aquela imposta pela isquemia. Tal lesão caracteriza-se por edema, dor muscular, fraqueza corporal, déficit funcional da musculatura e dano a órgãos distantes, como pulmão, fígado e rins. O fator de transcrição nuclear kappa B (NFKB), envolvido na regulação gênica de uma série de mediadores pró-inflamatórios produzidos durante o período de reperfusão, desempenha papel central na patogênese da lesão muscular por I/R. O éster fenetila do ácido cafeico (CAPE), um fenilpropanóide antioxidante derivado da própolis, é um potente e específico inibidor do NFKB. Diversos estudos relatam o efeito protetor do CAPE contra a lesão por I/ $\mathrm{R}$ em diversos tecidos. O presente estudo objetiva investigar o efeito do CAPE na lesão por I/R do músculo esquelético em ratos. Ratos machos Wistar foram divididos em quatro grupos. Um submetido à operação simulada, outro a 2 horas de isquemia por meio da técnica de torniquete do membro pélvico, outro a 2 horas de isquemia e subsequiente tratamento com solução salina e outro com CAPE, seguidos por 4 horas de reperfusão. O músculo gastrocnêmio foi analisado pela quantificação das aminotransferases alanina (ALT) e aspartato (AST) e da creatinina, mensuração tecidual do MOA e do GSH, avaliação da percentagem de água muscular, escore histológico do grau de lesão tecidual e avaliação funcional da marcha. $\mathrm{O}$ índice de apoptose mionuclear foi quantificado pela técnica do TUNEL. A infiltração intersticial de neutrófilos e mastócitos foi quantificada por microscopia óptica. O NFKB e o produto da peroxidação lipídica foram avaliados pela técnica de imuno-histoquímica para a subunidade p65 do NFKB e para o 4-hidroxinonenal (4HNE), respectivamente. Os animais submetidos à I/R muscular apresentaram importante aumento na concentração sérica das aminotransferases e da creatinina após a reperfusão, com concentrações significativamente menores pós-tratamento pelo CAPE. As concentrações teciduais de GSH diminuíram após a reperfusão em relação ao período isquêmico, e foram parcialmente recuperadas pelo tratamento com o CAPE. O escore histológico do grau de lesão tecidual, o escore funcional da marcha, a percentagem de água muscular, a quantidade de MOA tecidual, o índice de apoptose mionuclear e o infiltrado intersticial de neutrófilos e mastócitos, assim como o índice de imunomarcação pelo $4 \mathrm{HNE}$ e pela subunidade p65 do NFKB, foram mais elevados nos animais submetidos à I/R em comparação ao grupo isquemia. Entretanto, o tratamento com o CAPE reduziu significativamente todas estas alterações. O CAPE foi capaz de proteger o músculo esquelético contra a lesão por I/R em ratos. Este efeito está possivelmente relacionado à inibição da via de sinalização intracelular do NFKB e conseqüente redução da resposta inflamatória tecidual no período pós-reperfusão do músculo esquelético.

\title{
SAÚDE DA CRIANÇA E DOADOLESCENTE
}

\begin{abstract}
ALÉRGENOS RECOMBINANTES DE ÁCAROS E BARATAS : IMPORTÂNCIA NO DIAGNÓSTICO DE ALERGIA EM ADOLESCENTES COM ASMA, RINITE E ECZEMA, IDENTIFICADAS POR QUESTIONÁRIO PADRONIZADO (ISAAC-"INTERNATIONAL STUDY OF ASTHMA AND ALLERGIES IN CHILDHOOD")
\end{abstract}

\section{Patrícia Polles de Oliveira Jorge \\ Orientadora: Profa. Dra. Luisa Karla Paula Arruda \\ Tese de Doutorado apresentada em 25/09/2008}

Na prática clínica, testes cutâneos de hipersensibilidade imediata com extratos alergênicos naturais são frequentemente usados para o diagnóstico de alergia. Alérgenos recombinantes poderiam oferecer vantagens sobre extratos naturais, incluindo possibilidade de estabelecer o perfil de reatividade a alérginos individuais; utilização de reagentes purificados, livres de contaminantes ou compo- nentes não alergênicos; quantificação precisa permitindo melhor padronização. O objetivo do presente trabalho foi avaliar o uso de alérgenos recombinantes de ácaros e de baratas para diagnóstico de alergia em escolares de 13 e 14 anos com sintomas de asma, identificados por meio do questionário ISAAC, na cidade de São José do Rio Preto, e comparar resultados obtidos com alérgenos recombinantes àqueles obtidos com extratos naturais. Testes cutâneos de hipersensibilidade imediata foram realizados em 531 escolares (156 portadores de asma ativa, e 375 sem asma ativa), com extratos de D. pteronyssinus, Blattella germanica e 
Periplaneta americana, gato, cão, mistura de pólens de gramíneas, e mistura de fungos; e com alérgenos recombinantes (r) de Dermatophagoides (rDer p 1, rDer f 1, rDer p 2, rDer p 5, e mistura dos 4 alérgenos designada DM4); e alérgenos recombinantes de P. americana (rPer a 1 e rPer a 7) e B. germanica (rBla g 2, rBla g 4 e rBla g 5). Entre os escolares alérgicos a D. pteronyssinus, testes cutâneos positivos para DM4, rDer p 1, rDer p 2 e rDer p 5 foram encontrados em $75,5 \%, 45,1 \%, 69,3 \%$ e $34,6 \%$ dos escolares, respectivamente, e houve uma concordância elevada entre resultados de testes cutâneos com DM4 e extrato de D. pteronyssinus (índice kappa 0,7591). Para alérgenos de barata, houve concordância moderada para testes com rPer a 1 e/ou rPer a 7, e com extrato de P. americana,. e concordância baixa para testes com rBla g 2 e/ou rBla g 4 e/ou rBla g 5, e com extrato de B. germanica. Houve associação significante de testes cutâneos de hipersensibilidade imediatas positivos para extratos de D. pteronyssinus, P. americana, B. germanica, gato e cão, e para alérgenos recombinantes de ácaro e baratas (com exceção de Per a1), e presença de asma ativa em escolares. Embora o objetivo principal tenha sido estudar escolares com asma ativa, no grupo estudado foi encontrada uma proporção de escolares com rinite e eczema, identificadas pelo questionário ISAAC. A presença de testes cutâneos de hipersensibilidade imediata positivos para extratos de D. pteronyssinus, gato, cão e fungos, e para alérgenos recombinantes de ácaros, foi associada a presença de rinite; não houve associação significantes de sensibilização a barata e presença de rinite. Eczema foi encontrado em pequeno número de escolares e esteve associado a testes cutâneos positivos para P. americana e rPer a 7. Nossos resultados mostraram que testes cutâneos com alérgenos recombinantes de ácaros e baratas podem ser usados com segurança para o diagnóstico de alergia em escolares. Mistura de 4 alérgenos recombinantes de ácaros (rDer p 1, rDer f 1, rDer p 2 e rDer p 5) mostrou elevada sensibilidade e especificidade para diagnóstico, quando comparada a extrato comercial de D. pteronyssinus. Elevada especificidade, mas baixa sensibilidade foi observada para alérgenos recombinantes de baratas, indicando a necessidade de painel mais amplo para diagnóstico de alergia a barata.

\section{SEGURANÇA E IMUNOGENICIDADE À VACINA CONTRA VARICELA EM CRIANÇAS E ADOLES- CENTES COM DOENÇAS REUMÁTICAS}

\section{Gecilmara Cristina Salviato Pileggi}

Orientadora: Profa. Dra. Virginia Paes Leme Ferriani

Tese de Doutorado apresentada em 30/09/2008

Introdução: A segurança e eficácia da vacinação, particularmente com componentes vivos atenuados como a vacina contra varicela (VV), em pacientes portadores de doenças reumáticas é um tema polêmico. A varicela oferece um risco aumentado nestes pacientes. Não há informações sobre o uso e riscos da VV em pacientes portadores de doenças reumáticas. Os benefícios inerentes à imunização superam os riscos que porventura poderiam ocorrer.

Objetivo: identificar as crianças e adolescentes susceptíveis à varicela em uma população de pacientes com doenças reumáticas em vigência de terapia imunossupressora (IS) atendidas no serviço de reumatologia pediátrica do HCFMRP-USP e avaliar a segurança e a resposta à VV nestes pacientes.

População e Métodos: foram avaliados 98 pacientes quanto a imunidade à varicela e 22(2-20 anos) susceptíveis e 3 com resultado duvidoso com história pregressaa negativa para varicela foram selecionados para receber a vacina. 18 (3-19 anos) crianças e adolescentes saudáveis foram vacinadas como controles. Uma dose da vacina BIKEN (Aventis Pasteur) foi aplicada. Os títulos séricos de Ac antiVZV foram estimados por teste ELISA imediatamente antes, 4-6 semanas e 1 ano após a aplicação da VV. A atividade da doença de base foi avaliada em 4 momentos: 3 meses e 1 mês antes e 3 meses e 1 mês após a vacinação. Foi feita continua vigilância pós-vacinal para efeitos adversos.

Resultados: todos os 25 pacientes usavam methotrexate (MTX) no momento da vacinação, 13 deles também recebiam corticosteróide (CE), e em 5, outra droga IS estava associada (ciclosporina ou leflunomide). Dos 25 vacinados, 22 foram avaliados quanto à resposta à vacina. Títulos protetores de Ac contra VZV foram detectados em $12 / 22$ dos pacientes $(54,5 \%)$ e em $11 / 18$ dos controles $(61,1 \%)$ na dosagem de 4 a 6 semanas após a vacinação; a resposta foi duvidosa em 4 pacientes e 3 dos controles e os demais não responderam à vacina. Após 1 ano, 11/22 pacientes mantiveram títulos de Ac anti-VVZ protetores. Nenhum paciente apresentou doença varicela pós-vacinal ou qualquer outro efeito adverso grave após a aplicação da vacina. Após um período médio de observação de 26 meses (12 a 38), nenhum dos respondedores desenvolveu herpes-zoster ou varicela. Um paciente que não havia apresentado soro conversão desenvolveu varicela 13 meses após a vacina. Não houve piora, reativação da doença ou mudanças nas doses médias das medicações em uso nos três meses seguintes à vacinação. Nos pacientes com AIJ (17), houve uma significante diminuição no número médio de articulações em atividade no período pós-vacinação $(\mathrm{p}=0.009)$.

Conclusão: apesar do número de pacientes vacinados ser pequeno, a VV parece ser segura em pacientes com doenças reumáticas, mesmo nos que estão em uso de MTX eCE. 


\section{SAÚDE MENTAL}

\section{CARACTERIZAÇÃO CLÍNICA E SÓCIO-DEMOGRÁFICA DA POPULAÇÃO ATENDIDA POR UM SERVIÇO DE INTERCONSULTA DE TERAPIA OCUPACIONAL EM UM HOSPITAL GERAL UNI- VERSITÁRIO}

\author{
Maria Gabriela Junqueira Pernambuco Barboza Gomes \\ Orientador: Prof. Dr. José Alexandre de Souza Crippa \\ Dissertação de Mestrado apresentada em 28/07/2008
}

A Interconsulta Psiquiátrica é considerada uma área da Psiquiatria, que trabalha no Hospital Geral compondo uma equipe (Psiquiatria de Ligação) ou prestando seus serviços a uma equipe solicitante (Consultoria Psiquiátrica). $\mathrm{O}$ Serviço de Interconsulta em Psiquiatria (SIP) do Hospital das Clínicas da Faculdade de Medicina de Ribeirão Preto (HCFMRP-USP) teve início em março de 1978 e a Terapia Ocupacional passou a integrar esta equipe em 1999. O cotidiano hospitalar tem uma marca própria com obrigações como usar vestimentas, ter horários previamente estabelecidos para se alimentar, para cuidar de sua higiene e para receber visitas, inclusive dos familiares. Os terapeutas ocupacionais, como profissionais que lidam com o cotidiano do indivíduo, têm sido inseridos nas equipes multiprofissionais do Hospital Geral, contribuindo com seus conhecimentos teóricos e técnicos específicos para cuidar de pessoas hospitalizadas. Apesar das várias funções que a Terapia Ocupacional (TO) pode exercer no Serviço de Interconsulta, existe escassez de estudos publicados sobre o perfil sócio-demográfico dos pacientes atendidos, o que prejudica o planejamento de ações e o levantamento da necessidade de recursos humanos para aquele Serviço. O objetivo deste trabalho foi realizar um estudo retrospectivo dos Pedidos de Interconsulta (Pls) para a TO do Serviço de Interconsulta em Saúde Mental (SISMen) do HCFMRP-USP no período de janeiro de 2000 a dezembro de 2005 . Os sujeitos foram os indivíduos que estiveram internados nas enfermarias do campus do hospital universitário e para quem foi solicitada a assistência do Serviço de TO naquele período, perfazendo um total de 633 pacientes e 709 PIso. Os dados foram coletados mediante consulta dos Pls e dos prontuários dos pacientes. A maioria dos sujeitos consultados foi do sexo feminino, com ensino fundamental incompleto e houve distribuição equilibrada entre os solteiros e casados. Quanto à idade e à situação laboral, a média de idade dos pacientes foi de 39,2 anos e a maioria deles era autônoma ou aposentada, seguida de dona de casa. Verificou-se que a Clínica Médica foi a responsável por mais do que um terço dos Pedidos de Interconsulta feitos para o Serviço de TO, seguida das clínicas Unidade Metabólica e Psiquiatria respectivamente; o tempo médio de internação dos pacientes encaminhados para esse Serviço foi de 51 dias, sendo que a média de internação no HCFMRP-USP foi de 6,4 dias. Consequentemente, o gasto desses pacientes variou entre uma e 2,4 vezes mais do que os pacientes internados nesta instituição. A taxa média de encaminhamento para a TO do SISMen foi de $0,5 \%$, sendo que o motivo de solicitação mais freqüente esteve relacionado aos aspectos emocionais do indivíduo, seguido por fatores referentes à hospitalização. Estes dados, de modo geral, estão de acordo com a literatura nacional e internacional dos SIPs. Concluiu-se que há necessidade de um instrumento padronizado para avaliar a população atendida pelo Serviço de Interconsulta de TO e que alguns pontos merecem estudos mais detalhados como a possibilidade de existência de associações entre dados sócio-demográficos e clínicos e o encaminhamento dos pacientes para esse Serviço.

\section{CARACTERIZAÇÃO CLÍNICA-DEMOGRÁFICA DAS INTERNAÇÕES PSIQUIÁTRICAS NA RE- GIÃO DE RIBEIRÃO PRETO-SP ENTRE 1998 E 2004}

\section{Régis Eric Maia Barros}

Orientadora: Profa. Dra. Cristina Marta Del-Bem

Dissertação de Mestrado apresentada em 01/08/2008

No início de 1990, as internações psiquiátricas no Brasil constituíam-se a segunda fonte de despesas com internações hospitalares. A partir de 1992, com as diretrizes do Ministério da Saúde, houve mudanças na caracterização das internações. Os hospitais psiquiátricos, progressivamente, deixaram de constituir a base do sistema assistencial, com o aumento da rede de serviços extra-hospitalares. A XIII Diretoria Regional de Saúde (DRS XIII), com 
sede em Ribeirão Preto, foi submetida a estas diretrizes, levando à reorganização do atendimento de saúde mental. De modo que, no início da década de 1990, a DRS XIII dispunha de 685 leitos psiquiátricos para internações agudas. As taxas de ocupação chegavam a $96 \%$ e o tempo de permanência era elevado com grande número de reinternações. Com as diretrizes, houve redução para 114 leitos para internações agudas e, concomitantemente, houve uma ampliação dos serviços extra-hospitalares de saúde mental. Essas medidas levaram a uma diminuição do número de internações e na taxa de ocupação para 60 a $70 \%$. No entanto, a partir de 2003, passaram a ocorrer dificuldades para internação integral devido à falta de vagas. Esta pesquisa objetiva avaliar essas mudanças caracterizando as internações. Foi criado um banco de dados único utilizando dados armazenados nos banco de dados de cada hospital envolvido no estudo. Todas as internações entre os anos de 1998 a 2004 foram contabilizadas. Foram analisadas as seguintes variáveis: faixa etária, sexo, estado civil, ocupação, diagnósticos, procedência, distrito sanitário para pacientes que residiam em Ribeirão Preto, tempo de permanência, re-internações, giro leito e taxa de ocupação. Foram internados 5362 pacientes correspondendo a 11.208 internações com as seguintes proporções de distribuição: Hospital Psiquiátrico (47,8\%), Hospital Geral (14,1\%) e Emergência Psiquiátrica $(38,1 \%)$. As taxas de ocupação nos ser- viços de internação integral tiveram aumento nos últimos anos da pesquisa apesar do giro leito permanecer relativamente elevado. Não existiram marcantes diferenças entre os serviços em relação às características demográficas das internações, mantendo-se um padrão de predominância de pacientes do sexo masculino, adultos jovens, sem vínculos conjugais estáveis, inativos profissionalmente e provenientes da própria região de Ribeirão Preto. As internações mais curtas predominaram nos serviços, havendo maior proporção de internações prolongadas no Hospital Geral, provavelmente pela gravidade dos casos. A maior proporção das internações é proveniente de Ribeirão Preto, com predomínio daquelas oriundas do distrito atendido pelo Núcleo de Saúde Mental do Centro de Saúde Escola. Os diagnósticos mais encontrados em todos os serviços foram os transtornos relacionados ao uso de substâncias psicoativas, transtornos do humor, transtornos psicóticos e transtornos de personalidades, havendo algumas diferenças nas proporções entre os serviços. O número de re-internações aproxima-se de um quarto (1/4) das internações em cada ano. $\mathrm{O}$ aumento das internações pode está relacionado as limitações da rede de serviços extra-hospitalares. A emergência psiquiátrica foi responsável por cerca de $40 \%$ das internações no período do trabalho. Novos serviços extrahospitalares podem determinar melhorias na rede de atendimento.

\section{ESPECTROSCOPIA DE PRÓTON POR RESSONÂNCIA MAGNÉTICA DO HIPOCAMPO EM PA- CIENTES COM TRANSTORNO DO PÂNICO}

\section{Clarissa Maria Ferreira Trzesniak}

Orientador: Prof. Dr. José Alexandre de Souza Crippa

Dissertação de Mestrado apresentada em 12/08/2008

Introdução e objetivo: $\mathrm{O}$ transtorno de pânico (TP) é um distúrbio de ansiedade que afeta aproximadamente 3\% da população geral. Recentes teorias neuroanatômicas sobre o TP têm proposto extenso envolvimento do sistema límbico na fisiopatologia do transtorno. De fato, diversas pesquisas em neuroimagem estrutural e funcional têm demonstrado alterações em estruturas límbicas, tais como o hipocampo, em pacientes com TP. Apesar disso, não existem estudos que tenham avaliado a neuroquímica hipocampal no distúrbio. Portanto, o presente trabalho utilizou espectroscopia de próton por ressonância magnética $\left(\mathrm{H}^{1}-\right.$ ERM) para examinar possíveis anormalidades neuroquímicas hipocampais em pacientes com TP.

Método: Vinte e cinco pacientes portadores de TP de acordo com o critério do DSM-IV e 18 controles saudá- veis foram examinados. Os sujeitos foram balanceados quanto a gênero, idade, dominância manual, escolaridade e nível sócio-econômico. Os níveis de n-acetil-aspartato (NAA, tido como marcador da viabilidade neuronal) e de colina (col, envolvida na síntese e degradação de membranes celulares) foram quantificados em relação à creatina $(\mathrm{Cr}$, considerada relativamente estável entre indivíduos e em diferentes condições metabólicas) nos hipocampos direito e esquerdo. Para análise estatística dos dados, adotou-se como critério valores de $\mathrm{p}<0,05$.

Resultado: Comparados aos controles, os pacientes com TP demonstraram redução significativa de NAA/ $\mathrm{Cr}$ no hipocampo esquerdo. Nenhuma outra diferença foi constatada.

Conclusão: Este resultado é consistente com achados anteriores sobre disfunções hipocampais no TP e apresenta a primeira evidência sugerindo o envolvimento neuroquímico da estrutura no distúrbio. 


\section{IDENTIFICAÇÃO DE PROBLEMAS DE SAÚDE MENTAL ASSOCIADOS À QUEIXA ESCOLAR SEGUNDO O INSTRUMENTO DE AVALIAÇÃO DAWBA}

\section{Lylla Cysne Frota D’Abreu}

Orientadora: Profa. Dra. Edna Maria Marturano

Dissertação de Mestrado apresentada em 12/08/2008

Queixa escolar é um dos principais motivos de encaminhamento de crianças à rede pública de saúde e às clínicas-escola de psicologia. Estudos prévios sugerem que no segmento de crianças encaminhadas para atendimento com queixa escolar a prevalência de problemas de saúde mental é maior que na população geral. O presente trabalho teve como objetivo a identificação e classificação das áreas de dificuldade associadas à queixa escolar, em categorias compatíveis com a CID-10 e com o DSM-IV-TR ${ }^{\mathrm{TM}}$, além da descrição do perfil da clientela quanto a dados sócio-demográficos, nível intelectual, fonte de encaminhamento, profissional solicitante, outros acompanhamentos realizados na área de saúde e uso de medicação. Participaram 103 crianças, de seis a doze anos, inscritas em uma clínica-escola de psicologia vinculada ao SUS, com queixa de dificuldade de aprendi- zagem escolar. Foram feitas consultas aos prontuários e a aplicação junto ao responsável da versão brasileira' adaptada da Avaliação do Desenvolvimento e Bem-estar, em inglês, Development and Well-Being Assesment (DAWBA), entrevista de diagnóstico de transtornos mentais na infância e na adolescência que aponta áreas de dificuldade compatíveis com o DSM-IV- TR ${ }^{\mathrm{TM}}$, e a CID-10. Os resultados mostraram taxas de escolaridade dos pais abaixo da média do município, 90\% das crianças com história anterior de acompanhamentos na área de saúde e $29 \%$ fazendo uso atual de medicação psicotrópica. Também foi encontrada uma alta prevalência de dificuldades como transtorno hipercinético, transtorno desafiador de oposição, transtorno de conduta, ansiedade de separação, ansiedade generalizada e fobia específica. O trabalho oferece subsídios para a defesa de políticas públicas na área de saúde mental infantil e para o planejamento de tratamentos compatíveis com a demanda, contribuindo para a melhoria do atendimento à clientela e da formação de pessoal.

\section{VOLUMETRIA CEREBRAL DE PACIENTES ESQUIZOFRÊNICOS - COMPARAÇÃO ENTRE DOIS MÉTODOS DE ANÁLISE AUTOMÁTICA : ANIMAL E SPM}

\section{Thiago Borduqui Ferrari}

Orientador: Prof. Dr. Jaime Eduardo Cecílio Hallak

Dissertação de Mestrado apresentada em 25/08/2008

O avanço das técnicas de investigação morfométrica cerebral tem contribuído sobremaneira com a elucidação acerca da existência de alterações neuropatológicas ligadas à esquizofrenia. Desde os estudos de Kraepelin e Bleuler, que definiram a esquizofrenia como uma entidade patológica autônoma, diversas técnicas foram empregadas, entre elas, estudos histológicos post mortem, raios-x e pneumoencefalografia, porém, seus resultados não eram considerados consistentes. Com o recente desenvolvimento de técnicas de aquisição de imagem, como a Tomografia Computadorizada e a Ressonância Magnética, que permitiram avaliações mais precisas e com pouco maleficio aos pacientes, concomitantes com o desenvolvimento de técnicas de avaliação morfométrica destas imagens, a existência de alterações neuropatológicas ligadas à esquizofrenia pôde ser mais bem estudada. Os atuais estudos apontam como principais alterações a redução nos ventrículos, e em estruturas dos lobos frontal e temporal. Porém, nem sempre os achados são reproduzidos, sendo que a discrepância entre os achados geralmente é atribuída a fatores metodológicos como: amostras populacionais heterogêneas, diferentes procedimentos e t equipamentos utilizados na aquisição das imagens, diferentes técnicas de avaliação morfométrica. Apesar das criticas à diversidade metodológica, poucos estudos tem explorado de maneira quantitativa esta influência. Desta maneira, o presente trabalho i teve por objetivo (i) realizar um estudo morfométrico com 35 pacientes esquizofrênicos ! e 35 controles saudáveis e (ii) comparar o resultado obtido por dois diferentes softwares de análise, o Statistical Parametric Mapping -SPM -e o Automatic Nonlinear Image Matching and Anatomical Labeling -ANIMAL -mostrando que diferenças intrínsecas de cada software na metodologia de análise podem ter conduzido a diferentes resultados.

\section{NEUROCOGNIÇÃO E IDENTIFICAÇÃO DE EMOÇÕES FACIAIS EM PACIENTES ESQUIZOFRÊ- NICOS REFRATÁRIOS, NÃO-REFRATÁRIOS E FAMILIARES DE PRIMEIRO-GRAU}

João Paulo Machado de Sousa

Orientador: Prof. Dr. Jaime Eduardo Cecílio Hallak

Dissertação de Mestrado apresentada em 09/09/2008
Introdução e justificativa: A esquizofrenia é um transtorno psiquiátrico caracterizado, dentre outros sintomas, por progressiva deterioração neurocognitiva e desajustamento 
social. A pesquisa na área sugere que os problemas de adaptação na esquizofrenia podem estar relacionados a prejuízos no processamento de informações emocionais no ambiente. Supostamente, versões atenuadas destes prejuízos estariam presentes também em familiares em primeiro grau de portadores desta condição. As características da esquizofrenia são mais intensas em uma parcela de pacientes designados como refratários ao tratamento medicamentoso com os assim chamados antipsicóticos típicos, correspondente a entre $20 \%$ e $30 \%$ de todas as pessoas afetadas. Resultados de estudos recentes têm demonstrado efeitos significativos do medicamento clozapina -indicado para o tratamento da esquizofrenia refratária -sobre a neurocognição, mas não há estudos sobre os efeitos desta droga na identificação de emoções faciais.

Objetivos: Comparar o desempenho de pacientes refratários e responsivos ao tratamento medicamentoso em testes neurocognitivos e em uma tarefa de identificação de emoções faciais, envolvendo ainda grupos de familiares destes pacientes e voluntários saudáveis.

Método: $\mathrm{O}$ estudo contou com a participação de um total de 120 pessoas, divididas em oito grupos de 15 integrantes: (1) esquizofrênicos refratários em uso de clozapina, (2) esquizofrênicos não-refratários em uso de outros antipsicóticos, (3) familiares de pacientes refratários, (4) familiares de pacientes não-refratários e voluntários saudáveis pareados um a um com cada um dos grupos anteriores. $\mathrm{O}$ procedimento experimental para todos os participantes con- sistiu de avaliação clínica, testes cognitivos e tarefa de ídentificação de emoções faciais.

Resultados: Ambos os grupos de pacientes tiveram desempenho prejudicado no reconhecimento de expressões emocionais e nos testes cognitivos. Pacientes refratários em tratamento com clozapina consumiram mais tempo para a execução da tarefa, sem apresentarem, no entanto, número de erros significativamente maior que o do grupo controle. Pacientes não-refratários, embora não apresentando dilatação no tempo de reação, foram menos precisos no reconhecimento das emoções e tiveram pior desempenho nos testes cognitivos. A performance no teste de identificação de emoções se correlacionou com o desempenho nos testes cognitivos e com os escores da P ANSS e da BPRS. Os grupos de familiares não apresentaram diferenças significativas em relação aos voluntários saudáveis na tarefa de reconhecimento de emoções, embora os familiares de pacientes refratários apresentassem desempenho prejudicado no teste de memória operativa.

Conclusão: Tanto os esquizofrênicos refratários como os não-refratários possuem déficits para o reconhecimento de expressões faciais de emoção. A clozapina parece ser capaz de melhorar o desempenho cognitivo de pacientes refratários, o que aparentemente refletiu em maior precisão na identificação de emoções. Os resultados não são suficientes para sustentar que fantiliares de pacientes com esquizofrenia apresentam déficits nesta função.

\section{EFEITO DOS HORMÔNIOS SEXUAIS NO RECONHECIMENTO DE EXPRESSÕES FACIAIS DE EMOÇÕES BÁSICAS : DIFERENÇAS ENTRE OS SEXOS E FASES DO CICLO MENSTRUAL}

\section{Vinicius Guandalini Guapo \\ Orientadora: Profa. Dra. Cristina Marta Del-Bem \\ Dissertação de Mestrado apresentada em 17/09/2008}

Muitos transtornos neuropsiquiátricos têm demonstrado um importante dimorfismo sexual em sua incidência, sintomatologia e resposta ao tratamento. Apesar de extensiva investigação e crescente interesse nas diferenças das habilidades cognitivas e emocionais de homens e mulheres este problema continua indefinido. Estudos avaliando diferenças entre os sexos no reconhecimento de expressões faciais têm apresentado resultados diversos nesta importante habilidade social. Consideramos que os resultados contraditórios podem estar relacionados com a falta de um controle das fases do ciclo menstrual e do ambiente hormonal das mulheres testadas. O objetivo deste estudo foi comparar a habilidade de homens e mulheres no reconhecimento de expressões faciais e relacionar os resultados com a fase do ciclo menstrual das mulheres e com os níveis dos hormônios sexuais de todos os voluntár10s. Trinta mulhe- res saudáveis e oito- homens saudáveis foram divididos em quatro grupos: Folicular precoce (dias 1 a 5 do ciclo menstrual), Periovulatório (dias 12 a 14 do ciclo menstrual), Luteal (dias 21 a 23 do ciclo mentrual) e Homens. Todos os voluntários realizaram uma tarefa de expressões faciais com seis emoções básicas -raiva, medo, tristeza, asco, alegria e surpresa. Cada emoção foi digitalmente modificada de maneira a criar um gradiente de intensidade entre $10 \%$ e $100 \%$ em intervalos de $10 \%$. Amostras de sangue foram colhidas para dosagem de estrogênio, progesterona e testosterona. Acurácia na resposta foi analisada por ANOVA de medidas repetidas e valores de $\mathrm{p}<0.05$ foram considerados significantes. Os níveis de hormônios sexuais diferiram significativamente entre os grupos, com baixos níveis de estrogênio e progesterona no grupo Folicular precoce, altos níveis de estrogênio e baixos níveis de progesterona no grupo Periovulatório e altos níveis de estrogênio e progesterona no grupo Luteal. Os níveis de testosterona foram significantemente maiores no grupo Homens. As voluntárias no grupo Folicular precoce reconheceram raiva com maior acurácia 
que mulheres nos outros dois grupos (Periovulatório e Luteal) e também que os voluntários do sexo masculino. Esta maior acurácia no grupo Folicu.lar precoce deu-se em função de um maior reconhecimento de raiva em faces masculinas e não femininas. Mulheres no grupo Folicular precoce tiveram uma maior acurácia no reconhecimento de tristeza que mulheres no grupo luteal. Ainda, o grupo Folicular precoce reconheceu surpresa com menor acurácia que o grupo Luteal, apenas em expressões faciais de alta intensidade. Não foram encontradas diferenças entre os grupos no reconhecimento de asco, medo e alegria ou em qualquer emoção quando homens e mulheres foram comparados sem se levar em consideração o ciclo menstrual das mulheres. Estes resultados sugerem um efeito do ciclo menstrual na modu ação do processamento de emoções. Sugerem, ain$\mathrm{da}$, que algumas diferenças entre os sexos no processamento de emoções só podem ser elucidadas quando o ciclo menstrual das mulheres é levado em consideração. Um melhor reconhecimento de raiva e tristeza no grupo folicular precoce pode estar relacionado com alterações na função serotonérgica mediadas pelo estrogênio e seu papel no humor e no comportamento agressivo.

\section{EFEITO DO ESCITALOPRAM NO TESTE DA SIMULAÇÃO DE FALAR EM PÚBLICO}

\section{Cybele Garcia Leal}

Orientador: Prof. Dr. Francisco Silveira Guimarães

Tese de Doutorado apresentada em 22/09/2008

Os modelos experimentais com voluntários saudáveis têm a vantagem de produzir amostras mais homogêneas e de menor complexidade do ponto de vista das manifestações clínicas. Diversas evidências sugerem que o Teste da Simulação de Falar em Público (SFP) envolve os mesmos substratos neurais do Transtorno do Pânico (TP). Os estudos com desafios farmacológicos investigam o papel dos sistemas de neurotransmissores nas doenças mentais. Nesse sentido, a administração aguda de drogas que potencializam a neurotransmissão serotonérgica em voluntários saudáveis geralmente estimula o eixo hipotálamohipófise-adrenal. Contudo, há resultados controversos na literatura. Estudo recentemente realizado em nosso laboratório mostrou que o SFP não aumentou o cortisol salivar em pacientes com TP sintomáticos ou assintomáticos e em voluntários saudáveis. O escitalopram, o enantiômero ativo do citalopram, um inibidor seletivo da recaptação da serotonina, ainda não foi avaliado no modelo do SFP. O objetivo desse estudo, portanto, foi o de avaliar a administração aguda do escitalopram nesse teste. Voluntários sau- dáveis receberam, num estudo duplo- cego e randomizado, placebo $(n=12), 10(n=17)$ ou $20(n=14)$ mg de escitalopram e foram submetidos ao SFP após duas horas. A ansiedade subjetiva e os sintomas somáticos foram avaliados através da escala analógica visual do humor e da escala de sintomas somáticos. A pressão arterial, frequiência cardíaca e condutância da pele também foram medidas. O cortisol e prolactina plasmáticos foram dosados no basal, antes e após 0, 15, 30 e 60 minutos do SFP. Dez e 20 mg de escitalopram prolongaram a ansiedade induzida pelo SFP. A dose de 20 mg aumentou a confusão mental após duas horas da administração da droga e elevou o cortisol e prolactina plasmáticos após o SFP. Considerando a evidência que grupos neuroniais distintos de serotonina são regulados diferentemente, podemos interpretar esses resultados considerando que o escitalopram pode ter reduzido a serotonina no sistema serotonérgico mesolímbico que regula a resposta comportamental ao estresse, prolongando a ansiedade no SFP. E por outro lado, agindo no sistema serotonérgico que regula a resposta hormonal ao estresse, a droga pode ter produzido resposta neuroendócrina através do aumento de serotonina. Mais estudos são necessários para investigar essa possibilidade e para avaliar a utilidade do escitalopram como sonda neuroendócrina.

\section{NÍVEL SÉRICO DE GLUTAMATO, SERINA E GLICINA EM PACIENTES PORTADORES DE ESQUI- ZOFRENIA E SEUS FAMILIARES EM PRIMEIRO GRAU}

\section{Márcio Tiradentes Cunha \\ Orientador: Prof. Dr. Jaime Eduardo Cecílio Hallak \\ Dissertação de Mestrado apresentada em 24/09/2008}

Nas últimas duas décadas, alternativas à hipótese da disfunção da transmissão dopaminérgica na esquizofrenia têm sido buscadas intensamente, uma vez que as possi- bilidades terapêuticas que enfocam esse sistema não têm se mostrado satisfatoriamente eficientes. Um especial interesse tem recaído sobre uma provável disfunção da transmissão glutamatérgica, englobando aqui não somente o glutamato, mas também seus precursores, a serina e a glicina. Apesar dos diversos estudos que buscaram identificar alterações nesse sistema na esquizofrenia, ainda existem di- 
versas questões a serem respondidas. Uma delas diz respeito aos níveis plasmáticos destes aminoácidos. As evidências atualmente disponíveis são contraditórias no sentido de esclarecer qual a natureza destas alterações, se é que elas ocorrem. Assim, procuramos no presente estudo identificar se existem alterações nos níveis plasmáticos de pacientes portadores de esquizofrenia crônica em tratamento antipsicótico comparados com voluntários sadios. Além disso, buscamos identificar se tais alterações ocorrem em familiares de primeiro grau destes pacientes e se seria possível utilizá-Ias como possíveis marcadores de risco para o desenvolvimento da esquizofrenia ou como um preditor da resposta terapêutica. Assim, foram selecionados quinze pacientes esquizofrênicos em tratamento antipsicótico tradicional (denominados de responsivos) e seus familiares em primeiro grau, quinze pacientes esquizofrênicos em tratamento antipsicótico com clozapina (denominados de nãoresponsivos) e seus familiares e sessenta voluntários sadi- os emparelhados quanto ao gênero e idade. Em relação à glicina, foram encontradas diferenças significativas entre os grupos, com pacientes responsivos apresentando os maiores níveis plasmáticos. Quanto ao glutamato, foi encontrado um aumento dos níveis plasmáticos em pacientes não-responsivos comparados com pacientes responsivos e controles sadios. relação aos familiares, houve também diferenças entre os grupos, em que os familiares de pacientes responsivos apresentaram níveis menores que os outros familiares. Estes achados sugerem que pacientes esquizofrênicos considerados responsivos e não-responsivos em tratamento farmacológico e estabilizados diferem quanto aos níveis plasmáticos de glutamato e glicina, mas não de serina. $\mathrm{O}$ fato novo dessa pesquisa foi a verificação de uma alteração nos níveis de glutamato em familiares de pacientes esquizofrênicos, sem que os mesmos sejam portadores de esquizofrenia. Novas pesquisas são necessárias para que se confirmem e se compreendam esses resultados.

\title{
SAÚDE NA COMUNIDADE
}

\begin{abstract}
HOSPITALIZAÇÕES POR CAUSAS EXTERNAS, NA REGIÃO DE RIBEIRÃO PRETO, SP, EM 2005: ANÁLISE EPIDEMIOLÓGICA DESCRITIVA E AVALIAÇÃO DA QUALIDADE DOS REGISTROS EM HOSPITAIS SELECIONADOS
\end{abstract}

\section{Rosane Aparecida Monteiro}

Orientador: Prof. Dr. Juan Stuardo Yazlle Rocha

Dissertação de Mestrado apresentada em 05/08/2008

Introdução: os acidentes e violências, considerados como problema de saúde pública (OMS, 2002), muitas vezes têm desfecho final com episódio de morte e, em outras, na assistência hospitalar. A magnitude dessas causas externas e a morbimortalidade mostram representatividade importante para a epidemiologia dos agravos e doenças. Em decorrência disso, torna-se necessário conhecer a qualidade dos registros hospitalares, a fim de auxiliar a produção de conhecimentos epidemiológicos sobre as causas externas.

Objetivos: avaliar a qualidade e validar os códigos diagnósticos, através de estudo de confiabilidade dos dados registrados no Sistema de Informações Hospitalares (SIH) e do Centro de Processamento de Dados Hospitalares $(\mathrm{CPDH})$ comparados ao prontuário médico correspondente, em uma amostra de internações por causas externas em três hospitais selecionados. Descrever o perfil de morbimortalidade nas hospitalizações por causas externas na região de Ribeirão Preto, SP, em 2005, e identificar a subnotificação das causas externas em relação à natureza da lesão nas internações.
Metodologia: estudo descritivo e transversal, com abordagem quantitativa que se baseia em dados secundários de hospitalizações por causas externas, em 2005. A população selecionada é de pacientes residentes e atendidos na região de Ribeirão Preto, em 2005, com diagnóstico principal referente ao capítulo XIX da CID-10. Estudo realizado em duas partes: na primeira, estuda-se o perfil das hospitalizações por causas externas e as subnotificações dos registros das causas externas nos sistemas; na segunda parte foi selecionada da amostra aleatória de hospitalizações notificadas no sistema CPDH e prontuários. Para validação, utilizou-se como critério padrão-ouro os dados dos prontuários. Na análise de confiabilidade foi aplicado teste de sensibilidade para validação dos dados, com recursos dos aplicativos Epiinfo, Epidat e Excel.

Resultados: o perfil epidemiológico das hospitalizações, devido às causas externas, acomete mais a população de adultos jovens e do sexo masculino, em cerca de $70 \%$ dos pacientes. As quedas, primeira na lista das causas externas com $49 \%$, destacando-se a taxa de internação para os pacientes idosos, com 70 anos e mais, foi superior a 60 por 10 mil habitantes. Os acidentes de transporte terrestre ocuparam o segundo lugar com $15 \%$, sendo que, desses, a maioria era de motociclistas (36\%). As variáveis de identifica- 
ção do paciente (idade, sexo, procedência, tipo de convênio) em geral, tiveram ótima sensibilidade (95-99\%) em ambos os sistemas, a sensibilidade para a "natureza da lesão", registrada no $\mathrm{CPDH}$, foi de $72,8 \%$ e $\mathrm{SIH} 60,6 \%$. O sub-registro do tipo de causa externa nos prontuários, para o hospital com atendimento SUS foi de 0,05 (1 em 196); hospital misto, 17,9 (33 em 184) e hospital privado 69,1 (95 em142), respectivamente a sensibilidade dos dados eletrônicos $\mathrm{CPDH}$ em relação aos prontuários médico de pacientes para código diagnóstico principal com três caracteres (77,4 - 69,6 e 71,1). Quanto à sensibilidade no SIH para código diagnóstico principal três caracteres, o hospital SUS ficou com 68,8\% e hospital misto com 50,3\%. Outro achado foi o desdobramento com novas autorizações de internações hospitalares (AIHs) para a mesma internação, superestimando as causas externas em $8 \%$, destacam-se entre essas causas as internações decorrentes de acidentes com motociclistas, complicações de assistência médica/cirúrgica e as queimaduras.

Conclusão: conclui-se que as causas externas nas hospitalizações, têm sua porta principal de entrada por meio dos hospitais públicos. As quedas têm as taxas de hospitalizações mais elevadas entre as causas externas, porém alteram-se com o viés deinterpretação dos codificadores das AIHs. É preciso investir: padronização de conceitos sobre os eventos ocorridos, esforços dos codificadores para identificar códigos específicos e a sensibilizaçãodos profissionais médicos quanto à importância do preenchimento correto e completo da informação. Portanto, mesmo com as limitações dos sistemas de informações, esses não são fatores impeditivos para utilização como ferramentas para os gestores nas ações de planejamento, administração e para pesquisadores, contribuindo para a melhoria da saúde pública.

\section{ESTUDO EPIDEMIOLÓGICO EM POPULAÇÃO RURAL DO INTERIOR DO ESTADO DE SÃO PAULO COM ELEVADA PREVALÊNCIA DE HEPATITE C - SP"}

\author{
Sabrina de Brito Ramalho Luz Ferrão \\ Orientador: Prof. Dr. Afonso Dinis Costa Passos \\ Dissertação de Mestrado apresentada em 14/08/2008
}

A infecção pelo vírus da hepatite $\mathrm{C}$ acomete cerca de 180 milhões de pessoas em todo mundo. Trata-se de doença com pouca manifestação clinica, onde cerca de $75 \%$ a $85 \%$ dos casos evolui para cronificação e aproximadamente $15 \%$ para hepatocarcinoma. Entre os fatores de risco mais conhecidos estão a realização de transfusões de sangue e hemoderivados anterior a 1993, uso de drogas endovenosas e relações sexuais desprotegidas. Este trabalho tem por objetivo estimar a prevalência de sorologia positiva para hepatite $\mathrm{C}$ e seus possíveis fatores de risco no distrito de Botafogo, município de Bebedouro, SP, onde a elevada freqüência de casos de hepatite chamou a atenção dos seus próprios moradores. Da população de 1318 habitantes, 353 foram sorteados para participar da pesquisa, sendo submetidos a questionário padronizado e coleta de sangue. Infecção pelo vírus da hepatite $\mathrm{C}$ foi pesquisada através de exames imunoenzimáticos e de PCR, no Instituto Oswaldo Cruz (Fiocruz), e por teste imunocromatográfico, no Laboratório de Sorologia do Hospital da Clínicas de Ribeirão Preto-USP .A prevalência encontrada foi de 8,8\% ( $\left.\mathrm{IC}_{95 \%}: 5,8-11,7\right)$. As variáveis que mostraram associação na análise univariada foram submetidas a um procedimento multivariado por aplicação do modelo de log binomial. As variáveis preditoras independentes de infecção pela hepatite $\mathrm{C}$ foram sexo masculino, tempo de residência acima de trinta anos e uso de medicações parenterais com material esterilizado por técnica de fervura. Uma possível explicação para a elevada prevalência nessa população reside na possibilidade de disseminação do vírus a partir de um antigo morador, que exercia informalmente atividades ligadas ao atendimento à saúde, especialmente aplicação de injeções, numa época anterior ao uso de seringas descartáveis.

\section{EQUILÍBRIO EM IDOSOS E PRÁTICA DE TAI CHI CHUAN}

\section{Joab Jefferson da Silva Xavier}

Orientador: Professor Dr. Milton Roberto Laprega

Dissertação de Mestrado apresentada em 08/09/2008

O processo de envelhecimento populacional é uma realidade premente nas diversas sociedades atuais, com grande concentração de idosos especificamente nos países em desenvolvimento. $\mathrm{O}$ envelhecer muitas vezes leva o ser humano à condição de sedentarismo e à falta de atividade física que pode acarretar prejuízos no equilíbrio e resultar em aumento do número de quedas. O Tai Chi Chuan, arte marcial oriental de origem chinesa vem se destacando como uma das atividades de intensidade moderado de grande popularidade entre a população idosa em todo o mundo e; especificamente no Brasil, ainda são escassos os estudos que procuram verificar os benefícios do Tai Chi Chuan 
entre os idosos. Avaliar o equilíbrio de idosos cadastrados no Programa de Saúde da Família, na faixa etária dos 60 aos 70 anos em três tempos (antes, durante e após) de um programa de seis meses de Tai Chi Chuan constituiu o objetivo deste estudo. Realizamos uma pesquisa quantitativa com 21 idosos (65,5 \pm 2,7 anos de idade) sedentários, utilizando como instrumentos de avaliação: escala de equilíbrio de Berg e um questionário estruturado com características gerais e de saúde. Como recurso complementar utilizamos um roteiro de entrevista em grupo focal, técnica de abordagem qualitativa, para conhecer as percepções de idosos e da equipe de Saúde da Família em relação ao programa proposto. Quanto aos aspectos quantitativos obtivemos melhora significativa $(\mathrm{p}<0,01)$ entre os tempos da $1^{\mathrm{a}}$ e $3^{\mathrm{a}}$ avaliação de Berg. Na comparação entre os grupos em cada tempo e a escala de Berg, não foram observadas diferenças quanto ao gênero, idade, escolaridade, estado civil, aposentadoria, percepção subjetiva de saúde e audição, participação em casal ou não, comorbidades referidas e renda. Para as comparações entre os tempos em cada grupo e a escala de Berg foram observadas diferenças quanto ao gênero, idade, escolaridade, apo- sentadoria, percepção subjetiva de saúde e audição, participação em casal ou não, comorbidades referidas e renda ( $\mathrm{p}<0,01)$. Quando comparadas as médias das quedas durante os tempos foram observadas diferenças significativas na redução do número de quedas, tanto no sexo feminino quanto no masculino, da $1^{\mathrm{a}}$ para a $3^{\mathrm{a}}$ avaliação. quanto aos aspectos qualitativos constatamos pelas percepções dos idosos que a intervenção contribuiu para a melhora da postura, da respiração, da flexibilidade, reduziu o consumo de antiinflamatórios e estabeleceu um espaço de socialização entre eles; apesar da precária infra-estrutura do local onde foi realizada a pesquisa. Nas percepções levantadas pela equipe de Saúde da Família percebemos que o foco da atenção primária ainda é focado na doença devido em parte pelas grandes demandas por atendimento na população. Este estudo permitiu concluir que o Tai Chi Chuan pode ser uma oportunidade acessível, de baixo custo e agradável para a manutenção de um estilo de vida saudável e a provisão de cusidado para populações em processo de envelhecimento e que pode ser implementado no âmbito da Estratégia de Saúde da Família.

\section{CÁRIE DENTÁRIA, DESENVOLVIMENTO HUMANO E SERVIÇOS ODONTOLÓGICOS NO ESTA- DO DE SÃO PAULO, BRASIL, 2000-2006}

\section{Maria Alice Siqueira Zanin}

Orientador: Prof. Dr. Antonio Luiz Rodriguez Júnior

Dissertação de Mestrado apresentada em 16/09/2008

O Estado de São Paulo concentra grande número de cirurgiões-dentistas, mas a desigualdade social e de renda presentes e as diferenças na distribuição dos profissionais pelas suas regiões não colabora para a equidade na oferta e no acesso aos serviços odontológicos da Atenção Básica. Este estudo ecológico teve como objetivo descrever a relação entre indicadores de experiência da cárie dentária, desenvolvimento social, oferta e acesso aos serviços odontológicos, no período de 2000 a 2006, analisados segundo a área de abrangência dos Departamentos Regionais de Saúde do Estado de São Paulo (DRS). Foram utilizados indicadores obtidos a partir da revisão de documentos e consultas aos bancos de dados da Fundação Sistema Estadual de Análise de Dados (SEADE), do Departamento de Informática do SUS (DATASUS), do Instituto de Pesquisa Econômica Aplicada (IPEA), Instituto Brasileiro de Geografia e Estatística (IBGE) e da Secretaria de Estado da Saúde de São Paulo (SES-SP). As informações reunidas foram o indicador CPO-D (12 anos), Índice Desenvolvimento Humano dos municípios paulistas (IDH-M), o número de cirurgiões-dentistas $(\mathrm{CD})$ registrados no CRO-SP, o número de CD atuantes na área de saúde municipal e os Indicadores do Pacto da Atenção Básica 2006 para a saúde bucal.
Os dados foram organizados em mapas, utilizando-se análise de distribuição espacial, o que permitiu a observação visual de suas relações. Os menores valores do CPO-D foram encontrados em DRS (DRS I, DRS IV) que possuem maiores indicadores de desenvolvimento humano. Na região de baixo IDH-M (DRS XII) foi observada menor relação de CD registrados no CRO-SP, no serviço público e menor oferta e acesso aos serviços básicos de saúde bucal. DRS localizados em regiões de melhor IDH-M e mais populosos (DRS I, DRS IV, DRS VII) também demonstram certa dificuldade na oferta e acesso a esses serviços. A oferta foi maior nos DRS localizados ao norte do Estado e de menor tamanho populacional. Tanto em DRS de baixo como alto IDH-M a ação escovação dental supervisionada foi ofertada, mas com baixa cobertura. O percentual de procedimentos odontológicos especializados em relação às ações odontológicas individuais foi maior nos DRS localizados em regiões de alto IDH e naqueles que possuem Centro de Especialidades Odontológicas (CEO) instalados. A experiência de cárie dentária no Estado de São Paulo, no período de 2000 a 2006, mostrou correlação significativa com o indicador de desenvolvimento humano. A melhoria dos indicadores da saúde bucal depende de políticas abrangentes, direcionadas para o desenvolvimento humano e, também, de ações estratégicas voltadas para as populações de regiões que apresentam baixos indicadores socioeconômicos. 


\section{AVALIAÇÃO DA SAÚDE, CONDIÇÕES SOCIOECONÔMICAS E PARTICIPAÇÃo NA ESTRATÉ- GIA SAÚDE DA FAMÍLA}

\author{
Carolina Brunelli Álvares da Silva \\ Orientadora: $\operatorname{Prof}^{a}$. Dr ${ }^{a}$. Maria da Conceição Pereira Saraiva \\ Dissertação de Mestrado apresentada em 29/09/2008
}

Atualmente a atenção básica no sistema de saúde pública brasileiro, tem sido reorganizada pela Estratégia Saúde da Família (ESF). Este estudo tem como objetivo principal conhecer as características das famílias que se cadastram na ESF em relação àquelas que numa mesma área não se cadastram, para que, desta forma, possamos avaliar se as famílias cadastradas são realmente as mais necessitadas economicamente e em termos de atenção à saúde. Foi realizado um inquérito populacional na área de abrangência de um dos núcleos de saúde da família (NSF) no bairro Sumarezinho da cidade de Ribeirão Preto, São Paulo, Brasil. Participaram do sorteio da amostra a ser estudada todos os domicílios situados em sua a área de abrangência, independente de serem cadastrados ou não na ESF. A amostra foi estratificada pelas cinco microáreas pertencentes à área da unidade. Em cada microárea 15\% das famílias cadastradas (C) na ESF e 60\% das não cadastradas (NC) foram sorteadas. A coleta de informações foi realizada por meio de um questionário (completo) previamente elaborado, estruturado e pré-testado, aplicado a um membro da família. Foram coletadas informações de 209 famílias, relacionadas: à saúde geral e bucal, cobertura de plano de saúde médico e odontológico, condições socioeconômicas, dentre outras. Além disso, informações sobre o perfil de utilização da ESF pelas famílias $\mathrm{C}$ e os motivos para não participação das NC, foram também coletados. A análise descritiva foi seguida de análise bivariada entre os grupos de C e NC. Para variáveis contínuas, comparações de médias (teste $t$ ) apropriadas foram realizadas, e para variáveis categóricas, o teste de quiquadrado foi empregado.Foram construídos dois modelos de maneira hierárquica, para análise multivariável. $30,8 \%$ das famílias NC não tinham conhecimento da existência da ESF no bairro. Dentre as que já conheciam a não participação foi justificada pela posse de plano de saúde. Cerca de 28,0\% dos membros das famílias C não utilizam a ESF, a razão mais comum para isso é ter um plano de saúde ou não ter problemas de saúde. O principal motivo para utilização da ESF pelas famílias C é para realização de consultas de rotina. As famílias $\mathrm{C}$ têm em geral mais doenças diagnosticadas do que as $\mathrm{NC}$, especialmente artrite/artrose, diabetes, hipertensão, problemas cardíacos, asma e problemas de coluna.

Com base no modelo construído para todos as famílias participantes do estudo, as variáveis que melhor predisseram estar cadastrado na ESF foram escolaridade e ocupação do chefe da família, o tempo de moradia no bairro, porcentagem de pessoas com convênio de saúde e número de moradores. No modelo para as famílias que responderam questionário completo a classificação de poder de compra (ABEP) foi mais importante do que a escolaridade do chefe da família. A média de idade da família e a porcentagem de indivíduos embora não tenha sido estatisticamente significante ao ser incluída no modelo ( $\mathrm{p}=0.289)$, mostra que existe uma tendência de famílias com média de idade maior se cadastrar mais na ESF. 